\title{
Mission San Jose Repointing and Underpinning Project, San Antonio, Texas
}

Steve A. Tomka

Raba Kistner

Anne A. Fox

Center for Archaeological Research

Barbara A. Meissner

Center for Archaeological Research

Follow this and additional works at: https://scholarworks.sfasu.edu/ita

Part of the American Material Culture Commons, Archaeological Anthropology Commons, Environmental Studies Commons, Other American Studies Commons, Other Arts and Humanities Commons, Other History of Art, Architecture, and Archaeology Commons, and the United States History Commons

Tell us how this article helped you.

This Article is brought to you for free and open access by the Center for Regional Heritage Research at SFA ScholarWorks. It has been accepted for inclusion in Index of Texas Archaeology: Open Access Gray Literature from the Lone Star State by an authorized editor of SFA ScholarWorks. For more information, please contact cdsscholarworks@sfasu.edu. 


\section{Mission San Jose Repointing and Underpinning Project, San Antonio, Texas}

Creative Commons License

(c) (i) (8)

This work is licensed under a Creative Commons Attribution-NonCommercial 4.0 International License 


\title{
Mission San José \\ Repointing and Underpinning Project, San Antonio, Texas
}

\author{
Steve A. Tomka, Anne A. Fox, \\ and Barbara A. Meissner
}

with an Appendix on Removal and Installation of Signs at Missions San José, San Juan, Concepción, and Espada by Jeffrey J. Durst

Robert J. Hard and C. Britt Bousman Principal Investigators

Texas Antiquities Permit No. 1841

Ccopyright 1999

Center for Archaeological Research The University of Texas at San Antonio Archaeological Survey Report, No. 294 
The following information is provided in accordance with the General Rules of Practice and Procedure, Chapter 41.11 (Investigative Reports), Texas Antiquities Committee:

1. Type of investigation: Shovel Testing, Excavation, and Monitoring

2. Project name: San José Indian Quarters Stabilization Project

3. County: Bexar

4. Principal investigators: Robert J. Hard and C. Britt Bousman

5. Name and location of sponsoring agency: National Park Service, San Antonio Missions National Historical Park, San Antonio, Texas

6. Texas Antiquities Permit No.: 1841

7. National Park Service Contract Numbers: 1443PX7600-97053, 1443PX7600-98028

8. Published by the Center for Archaeological Research, The University of Texas at San Antonio, 6900 N. Loop 1604 W., San Antonio, Texas 78249-0658, 1999

A list of publications offered by the Center for Archaeological Research is available. Call (210) 458-4378; write to the Center for Archaeological Research, The University of Texas at San Antonio, 6900 N. Loop 1604 W., San Antonio, Texas 78249-0658; e-mail to car@1onestar.utsa.edu; or visit CAR's web site at http://csbs3.utsa.edu/car. 


\begin{abstract}
This report contains the results of archaeological work performed by the Center for Archaeological Research (CAR) for the National Park Service (NPS) under Contract Numbers: 1443PX7600-97053 and 1443PX760098028. Both projects were carried out under Texas Historical Commission Permit Number 1841. The bulk of the report deals with the results of shovel testing and archaeological excavations conducted as part of the Indian Quarters Stabilization project at Mission San José y San Miguel de Aguayo (41BX3) for the San Antonio Missions National Historical Park. Appendix 1 of this report contains the results of shovel testing and the monitoring of sign removal and installation conducted at Mission San Juan, Mission Espada, Mission Concepción, and Mission San José as part of the Missions Signage Removal/Installation Project.

Mission San José is located ca. seven miles south of downtown San Antonio on a high terrace overlooking the west bank of the San Antonio River. On October 27 and 29, 1997, CAR personnel excavated a total of 39 shovel tests (ST) along the southern, eastern, and western outer walls of the mission. The test excavations were conducted in preparation for grade alterations to be undertaken along the exterior and interior walls of the mission compound.
\end{abstract}

In June and late July 1998, CAR personnel conducted excavations outside the south wall and within Room 54 adjacent to the western corner of the southeast gate of the mission. These excavations were undertaken to mitigate the impact of underpinning efforts on the southwest corner of the Southeast Gate of the mission being undertaken by the NPS through a major construction contract.

The shovel testing and excavations showed that: 1) some high density artifact concentrations are present outside of the western and eastern mission walls possibly representing colonial middens; 2) a large portion of the soils and cultural materials found immediately adjacent the south wall of the mission show signs of disturbance from the Civil Works Administration (CWA) efforts to relocate the colonial foundation and outer walls of the mission; 3) much of the cultural material-bearing matrix found along the south wall of the mission, inside Room 54, is also disturbed to a depth of approximately 19 inches bs, and 4) a colonial living surface exists immediately below the disturbed zone in portions of the interior of Room 54 and under the southeast gate.

Due to the urgency of the construction contractor to complete the regrading and underpinning efforts to reduce erosion and stabilize the southwest corner of the southeast gate, work on these projects proceeded concurrently and immediately following the archaeological investigations. However, it is the opinion of CAR that the regrading project impacted no intact cultural materials and, in fact, may have served to preserve, through burial, future disturbances to the deeper buried (less disturbed) colonial zone. In addition, the archaeological investigations conducted by CAR have recovered significant data and mitigated the impact of construction activities related to the underpinning of the southwest corner of the southeast gate. We commend the NPS and the construction contractor for their cooperation and collaboration in these efforts. 


\section{Contents}

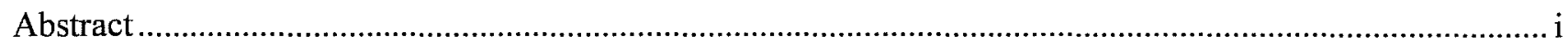

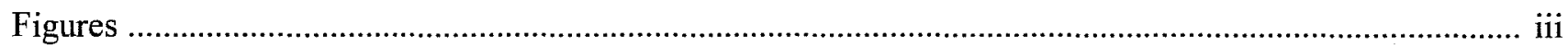

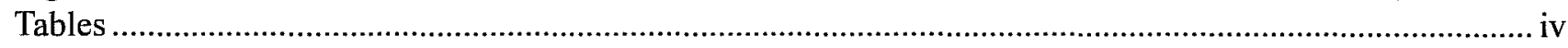

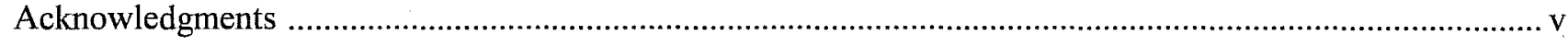

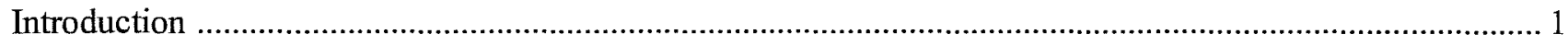

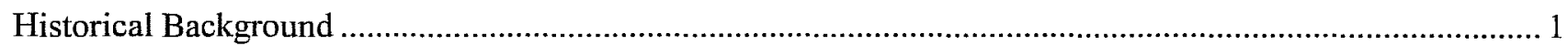

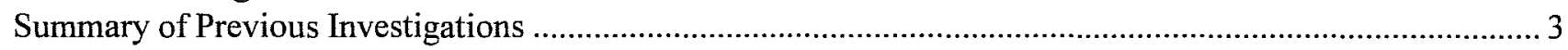

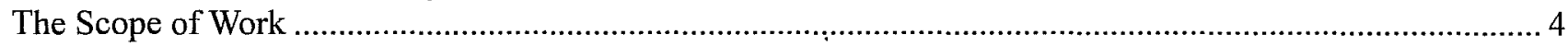

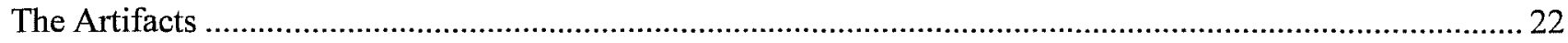

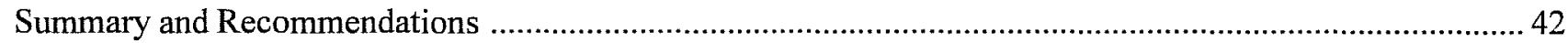

References Cited ......................................................................................................................45

Appendix 1: San Antonio Missions Signage Removal and Installation Project:

Shovel Testing and Monitoring at Missions San José, San Juan, Concepción, and Espada .................... 53 


\section{Figures}

1. Location of Mission San José San Miguel de Aguayo …………….................................................... 2

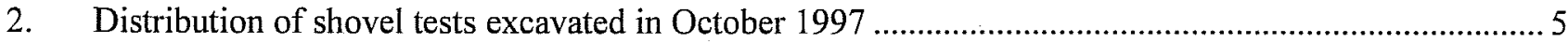

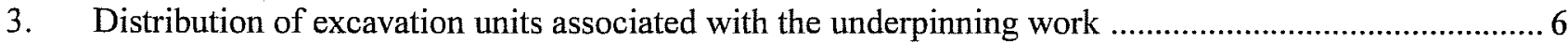

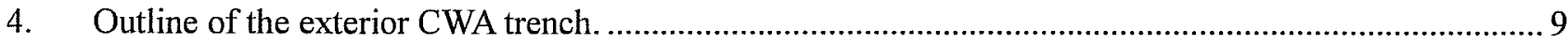

5. CWA foundation running perpendicular to south wall of Indian Quarters in Room $54 \ldots \ldots \ldots \ldots \ldots \ldots \ldots \ldots \ldots . . . . . . . . .14$

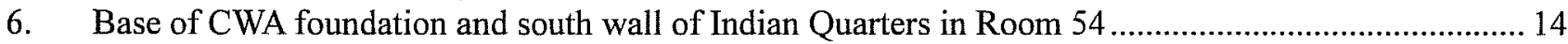

7. Contact between CWA foundation and south wall of Indian Quarters ................................................ 15

8. Feature 1, foot support rocks used to stabilize CWA construction scaffolding along inside of Indian Quarters south wall ................................................................................. 16

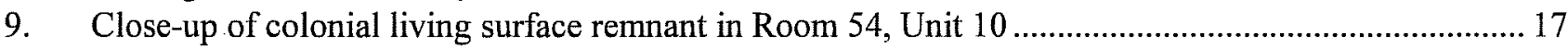

10. Concrete footing for former gate post at southwest corner of southeast gate ………..............................2 20

11. Chronology of South Texas historic ceramics ....................................................................................2

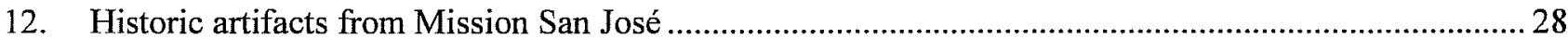

13. Chipped lithic artifacts from Mission San José ..................................................................................... 32

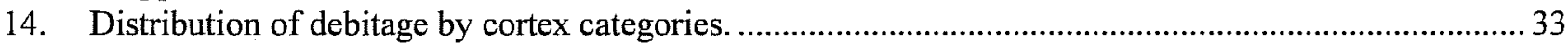

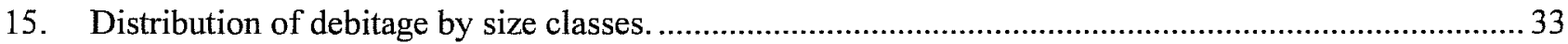

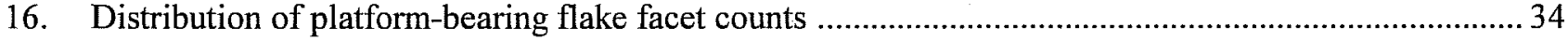

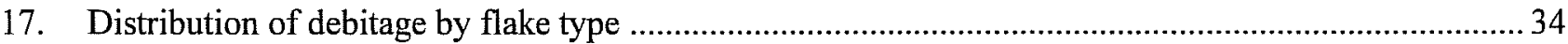

1-1. Location of signage-related activities at Mission San José …………………………......................... 54

1-2. Location of signage-related activities at Mission San Juan .................................................................... 56

1-3. Location of signage-related activities at Mission Espada ………....................................................... 57

1-4. Location of signage-related activities at Mission Concepción ................................................................ 58 


\section{Tables}

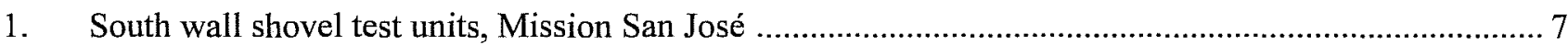

2. East wall shovel test units, Mission San José ....................................................................... 7

3. West wall shovel test units, Mission San José …..................................................................... 8

4. Artifacts from south wall shovel test units, Mission San José ....................................................... 10

5. Ceramics from south wall shovel test units, Mission San José ................................................... 11

6. Artifacts from east wall shovel test units, Mission San José ....................................................... 11

7. Ceramics from east wall shovel test units, Mission San José ..................................................... 12

8. Artifacts from west wall shovel test units, Mission San José .................................................... 13

9. Ceramics from west wall shovel test units, Mission San José ................................................... 13

10. Artifacts from Room 54 interior units, by excavation unit ......................................................... 15

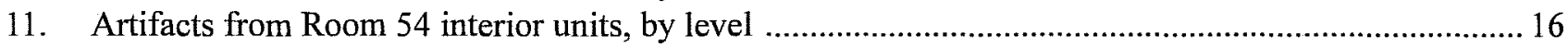

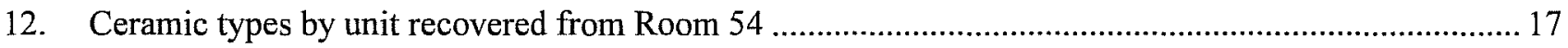

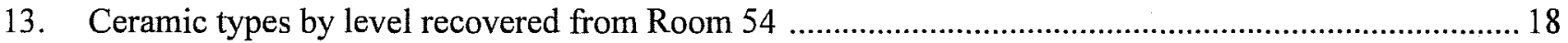

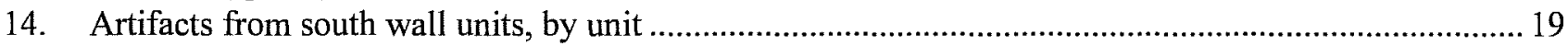

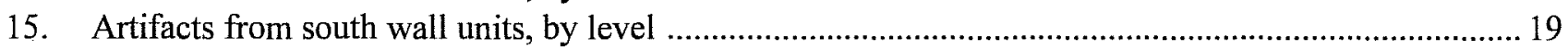

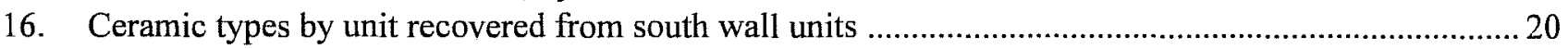

17. Ceramic types by level recovered from south wall levels ........................................................21

18. Artifacts recovered from west wall units of southeast gate, by unit .......................................... 21

19. Artifacts recovered from west wall units of southeast gate, by level ............................................2 21

20. All artifacts from shovel testing and underpinning excavation units, Mission San José ...................... 22

21. All ceramics recovered from underpinning testing and excavations at Mission San José .....................2 24

22. Unglazed ceramics recovered from Mission San José ............................................................... 24

23. Lead glazed ceramics recovered from Mission San José ............................................................ 24

24. Tin-glazed ceramics recovered from Mission San José .................................................................25

25. Whiteware ceramics recovered from Mission San José .............................................................26

26. Other ceramic wares recovered from Mission San José ................................................................26

27. Chipped lithic tools recovered from shovel testing and excavations associated with southeast gate underpinning, Mission San José .................................................... 31

28. Identified taxa from Mission San José underpinning shovel testing and excavation. ...........................36

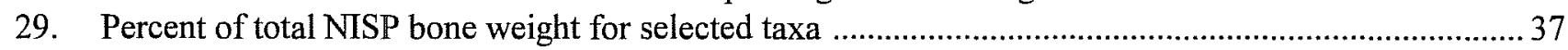

30. Comparison of bone weathering inside and outside the South Wall .............................................. 37

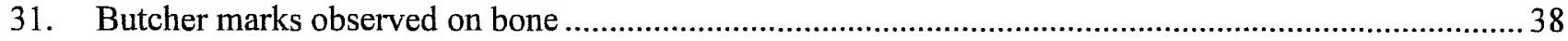

32. Comparison of bone counts, weights, and NISP in seven recent excavations at San José, with a sample from an earlier excavation.......................................................................... 38

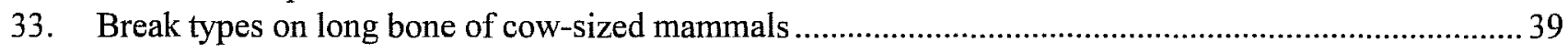

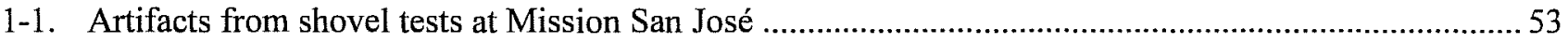

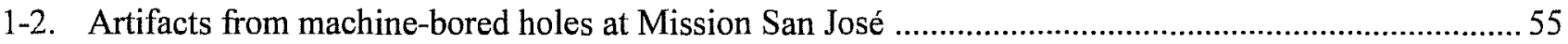

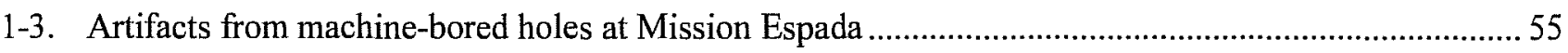




\section{Acknowledgments}

The successful completion of this project is owed to a large number of people. The able and hard working field crew and lab technicians that helped excavate and process the large quantity of materials obtained during the test excavations were indispensable. They include the following individuals: Connie Gibson, Chris Horrell, Anthony Lyle, Preston McWhorter, Clemente Murguia, Gloria Murguia, and Rick Robinson. San Antonio Missions National Historical Park Superintendent Stephen E. Whitesell, and Assistant Superintendent Mary A. Bomar facilitated the project in many ways. Mark Chavez, Chief, Division of Professional Services addressed in a timely manner each and every inquiry and field consultation and served as an able communicator between CAR and construction personnel. In addition, Doug Campbell, construction company job superintendent, facilitated the work of the archaeology crews and made the process enjoyable. We gratefully acknowledge the support of the CAR staff, in particular director Robert J. Hard, associate director C. Britt Bousman, small project coordinator Brett A. Houk and technical editor Bill Bishel. The figures were drafted by Chris Butler and Chris Horrell. 



\section{Introduction}

\author{
Steve A. Tomka
}

Pursuant to contract number 97053 between the $\mathrm{Na}$ tional Park Service (NPS) and the Center for Archaeological Research (CAR) of The University of Texas at San Antonio (UTSA), CAR personnel undertook shovel test excavations along the east, west, and south walls of Mission San José y San Miguel de Aguayo during October 1997. These test excavations were conducted in preparation for grade alterations to be undertaken along the exterior and interior Indian Quarters walls of the mission compound. These activities consisted of raising the grade at the existing building and mission walls to achieve a 2-4 percent slope away from the base of the walls. Some grading was to be carried out to create a flat subsurface before fill was to be added. The fill was to be blended to existing grade along the exterior of the compound and the brick walk within the interior. A total of 39 shovel tests were excavated to explore the nature of the subsurface deposits outside the eastern, western, and southern walls of the mission.

During June and July 1998 CAR personnel undertook extensive excavations along the southwest corner of the southeast gate both along the outside of the gate walls and within Room 54 along the east and south walls. These excavations were carried out in conjunction with the underpinning of the gate wall conducted by a construction company hired by the NPS. Underpinning activities necessitated the excavation of 3-6 foot wide trenches along the bases of the walls and the removal of all of the colonial foundation under the Civil Works Administration (CWA) Indian Quarters walls to allow the construction of reinforced concrete footings.

Mission San José y San Miguel de Aguayo is a designated State Archaeological Landmark (SAL). It is one of four local missions under the auspices of NPS within San Antonio Missions National Historical Park and bears the state archaeological site trinomial number 41BX3 (Figure 1).

The excavations were carried out in compliance with Section 106 of the National Historic Preservation Act of 1966 (as amended), under Texas Antiquities Permit No. 1841. The fieldwork was accomplished in a combined total of 17 workdays by a crew of four to seven individuals. Serving as principal and co-principal investigators were Robert J. Hard and C. Britt Bousman, respectively. The project archaeologist was Steve A. Tomka. The CAR staff and field crew consisted of Connie Gibson, Chris Horrell, Anthony Lyle, Preston McWhorter, Clemente Murguia, Gloria Murguia, and Rick Robinson.

\section{Historical Background}

\section{Anne A. Fox}

Mission San José y San Miguel de Aguayo was founded in February 1720 on the east bank of the San Antonio River about 3.5 miles south of Mission San Antonio de Valero (the Alamo). By the following spring, 227 Indians resided there (Habig 1968a:86). The mission was refounded across the river to its present location sometime between 1724 and 1727 . Constructed during the following 70 years were a granary, a friary, stone Indian houses, and a stone church (Habig 1978). By 1789 the mission was enclosed by a series of apartments comprising quarters for the Indian neophytes forming a walled enclosure with four bastions and six gates. The Indian population began to decline in the last quarter of the eighteenth century, and, by 1791 , only 106 Indians remained in residence (Habig 1968a: 103). Secularization of the mission began in 1794 when the property was divided among the 93 remaining Indians. During the nineteenth century the population consisted of local families who had taken up residence in and around the mission. A gradual decline in use and a lack of interest on the part of San Antonians allowed deterioration of the mission buildings. Vandalism, combined with the weathering of unprotected architecture, caused the north wall of the church to collapse in 1868 , which in turn caused the later collapse of the dome as well (Habig 1968b:148). The spiral staircase for the church tower fell in 1903. Although the staircase was restored in 1920 , the tower itself partially collapsed in 1928 .

After Bexar County obtained title to the various plots of land in the vicinity to create a park, the Civil Works 


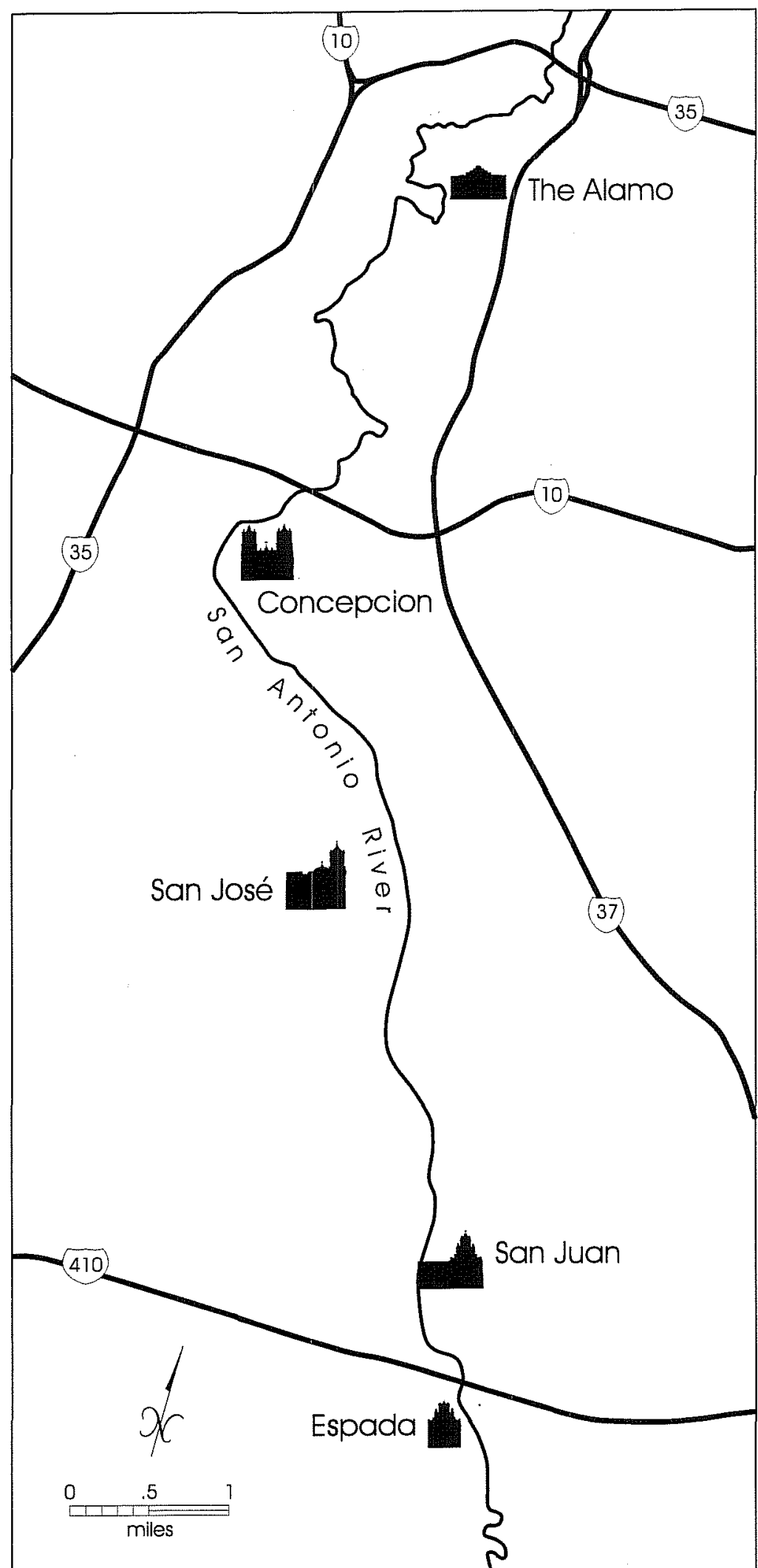

Figure 1. Location of Mission San José San Miguel de Aguayo.
Administration (CWA) began in 1933 the reconstruction of the original south, west, and east walls of the mission, which had been the Indian Quarters. On May 8, 1941, the entire site was acquired by the state of Texas, and San José was designated a National Historic Site (Habig 1968b: 185186). On February 20, 1983, Mission San José and three other San Antonio missions were combined into the San Antonio Missions National Historical Park.

No documentary descriptions have so far been found that indicate the method of construction or the exact location of the Indian Quarters during the first years of San José's existence on its present site. It was customary, however, for the first, temporary buildings on a Spanish colonial site to be of jacal construction, a method that involved setting upright logs into trenches to form walls, over which a thatched roof was constructed.

By 1749, Father Ciprián reported that at least some of the Indian houses were made of stone (Habig 1968a:49). Of 84 Indian apartments in 1755, 12 were of stone and consisted of two rooms each. They were arranged in "street-like form" (Leutenegger et al. 1978:115). This layout resembles those described for the earliest years at missions San Juan Capistrano (Schuetz 1968:33) and San Antonio de Valero (Fox et al. 1976:3). Governor Barrios in 1758 described the Indian Quarters as consisting of eight units or squares of stone with flat roofs and parapets arranged within a larger square (Habig 1968a:5051). By the time of the visit of Father Gaspar de Solís in 1768, the Indian apartments were stone structures formed as a part of the perimeter walls (Habig 1968a:55). This description was confirmed by Father Juan Agustín Morfi in 1777 (Habig 1968a:68). 
After the secularization of the mission in 1794 and the division of the property, the houses of the Indian Quarters that were unoccupied began to deteriorate. Some were replaced by frame houses as the mid-nineteenth century approached. By the early twentieth century, the mission was the center of a small settlement composed primarily of the descendants of the first landowners (Hard et al. 1995:3-8). A 1905 United States Geological Survey map and an aerial photograph taken 15 years later indicate small structures stood along the south, west, and east sides of the compound, most of them of frame construction. A few traces of the original walls still existed as ruins.

By the time of the CWA reconstruction of the mission walls in 1933, the only trace of the original Indian Quarters visible above the ground was a small section of one apartment at the southwest corner, visible on aerial photographs but probably hardly noticeable from ground level (Hard et al. 1995: Figure 5). The foundations of the original walls were relocated by the CWA workers under the instructions of architect Harvey Smith and the new walls were then built on these foundations. This has since been confirmed by various archaeological excavations and by Fox's observations of small construction projects on the site since 1971.

\section{Summary of Previous Investigations}

\author{
Anne A. Fox
}

Several archaeological investigations have been carried out at Mission San José in the past 30 years. Although only one of them has involved excavation of the Indian Quarters, each investigation has added to our knowledge of the architecture and the artifactual deposits present on the site.

In 1968, Mardith Schuetz (1970) of the Witte Museum monitored and recovered artifacts from a series of trenches dug throughout the mission compound for the installation of a sprinkler system. The trenches averaged 12 inches in depth. The trenches and their laterals extended not only across the interior of the compound but also outside and parallel to the south, west, and north walls. Several buried foundations were encountered within the mission. Few field notes were taken, and the report consists mostly of lists of artifacts recovered from each trench and a few brief descriptions of features encountered.

In 1970, Daniel Fox (1970) reported several monitoring operations previously carried out as well as testing he conducted in the vicinity of the north wall of the mission. Included in this report are descriptions of monitoring of a large sewer line trench dug in December 1969 parallel to and north of the north wall of the mission, and an electrical line trench dug just north of the church in April 1970. The third section of the report deals with the excavation in August 1970 of a 2.5-x-3-m test pit north of the church where a persimmon tree was to be planted. Also mentioned is a drainage trench $30 \mathrm{~cm}$ wide and $40 \mathrm{~cm}$ deep dug by workers for a pipe to carry water from the church entrance patio to a drain east of the north wall rooms.

In 1974, John Clark (1978) of the Texas Historical Commission conducted test excavations in a number of locations around the mission buildings to study the effects of climatic conditions on the major structures. This involved the excavation of eight test units, generally $1 \times 2 \mathrm{~m}$, in 20 -cm levels. Clark also included much useful information of the history and construction of the various buildings at the mission and a detailed plan showing all disturbances that had occurred and archaeological units that had been excavated at the mission up to that time.

In 1979, John Clark and Elton Prewitt conducted a testing operation to the west of the granary in preparation for the proposed installation of a French drain that was "intended to relieve moisture-related structural problems along the west wall of the granary" (Clark and Prewitt 1979:iii). Six 0.5-x-1-m test pits were excavated in the area to be affected. These revealed a remnant of a flagstone surface and a number of pits and other disturbances. Artifactual evidence of Spanish colonial and later uses of the area eventually caused a reconsideration of the original plan to install the drain.

When improvements were planned to Napier Avenue in 1984, the Texas Department of Transportation conducted investigations in the roadbed, locating a num- 
ber of features (Henderson and Clark 1984). Among these were a section of an acequia lateral southeast of the mission compound, a nineteenth-century burial dug into the west bank of that feature, and what appeared to be a colonial foundation trench ca. $100 \mathrm{ft}$ outside the south wall of the mission. The latter contained a number of post holes, suggesting that it represented a corral structure. Colonial and later period artifacts were recovered.

In 1991, CAR conducted archival research and backhoe testing to locate and map the acequia outside the east wall of the mission in preparation for the construction of a parking area for a new visitor center (Fox and Cox 1991). The exact location of the acequia madre or main ditch was determined by excavating two backhoe trenches perpendicular to the suspected path of the acequia and following out the line of the feature based on early maps of the area. The ditch was found to contain late nineteenth-century and early twentieth-century fill. An acequia lateral first located by Henderson and Clark (1984) was relocated and mapped by crossing it periodically with backhoe cuts (Fox and Cox 1991: Figure 3). This investigation resulted in the recommendation that subsurface preparation for the parking lot avoid excavating deeper than one foot below the ground surface.

CAR conducted test excavations at the southeast gateway and throughout the interior compound of the mission in 1993 (Hard et al. 1995) and additional excavations at the gateway in 1996 (Tennis 1997). These investigations included two 4'- $x-4$ ' excavation units within the gateway which revealed the construction of the nineteenth-century road that ran through the area and the original location of the mission walls. The testing within the compound yielded information on the nature and depth of mission period and later deposits, making it possible to plan needed changes in the drainage patterns within the compound.

The most recent excavations pertinent to the present project were conducted by CAR archaeologists in the vicinity of the southeast gate of the mission during the summer and fall of 1997 (Tomka and Fox 1998), and the spring of 1998 (Tomka and Fox 1999). The earlier projects included excavation of three $3 '-x-3$ ' units under the first drain immediately adjacent the southeast gate, an additional unit some 10 feet west, and two units within Room 54 immediately adjoining the gate. The spring fieldwork involved the excavation of a $6^{\prime}-x-9^{\prime}$ block of contiguous units ( 6 units each) under each of the first, second, and third canales (roof drains) west of the southeast gate. These excavations revealed the relationship between the reconstruction wall base and the colonial foundation, and suggested the presence of a colonial-period living surface under the road base in Room 54 .

\section{The Scope of Work}

Steve A. Tomka

\section{The Shovel Testing Project}

According to NPS plans, the area to be affected by the grade work extended no further than 20 feet from the mission walls, and no deeper than 12 inches bs. To investigate the affect these activities would have on potential cultural remains, 39 shovel tests were excavated along the east, west, and south mission walls (Figure 2). The shovel tests were excavated to a depth of 12 inches bs. The excavations had two general goals: to ascertain the presence and depth at which cultural materials occurred around the three sides of the mission; and to determine the age of the cultural materials that may be encountered by the regrading activities.

\section{The Underpinning Project}

The activities associated with the underpinning of the western corner of the southeast gate involved the removal of the colonial foundation underlying the CWA wall and its replacement with a continuous reinforced concrete foundation. To accomplish these goals all of the cultural-bearing matrix was to be excavated on the inside and outside of the southwest corner of the southeast gate (Figure 3). Excavations were to extend to a depth of 30 inches bs, terminating between 2-4 inches below the base of the colonial foundation. Samples of the caliche colonial foundation also were to be recovered by archaeologists and the foundation was to be removed in stages by the contractor's em- 


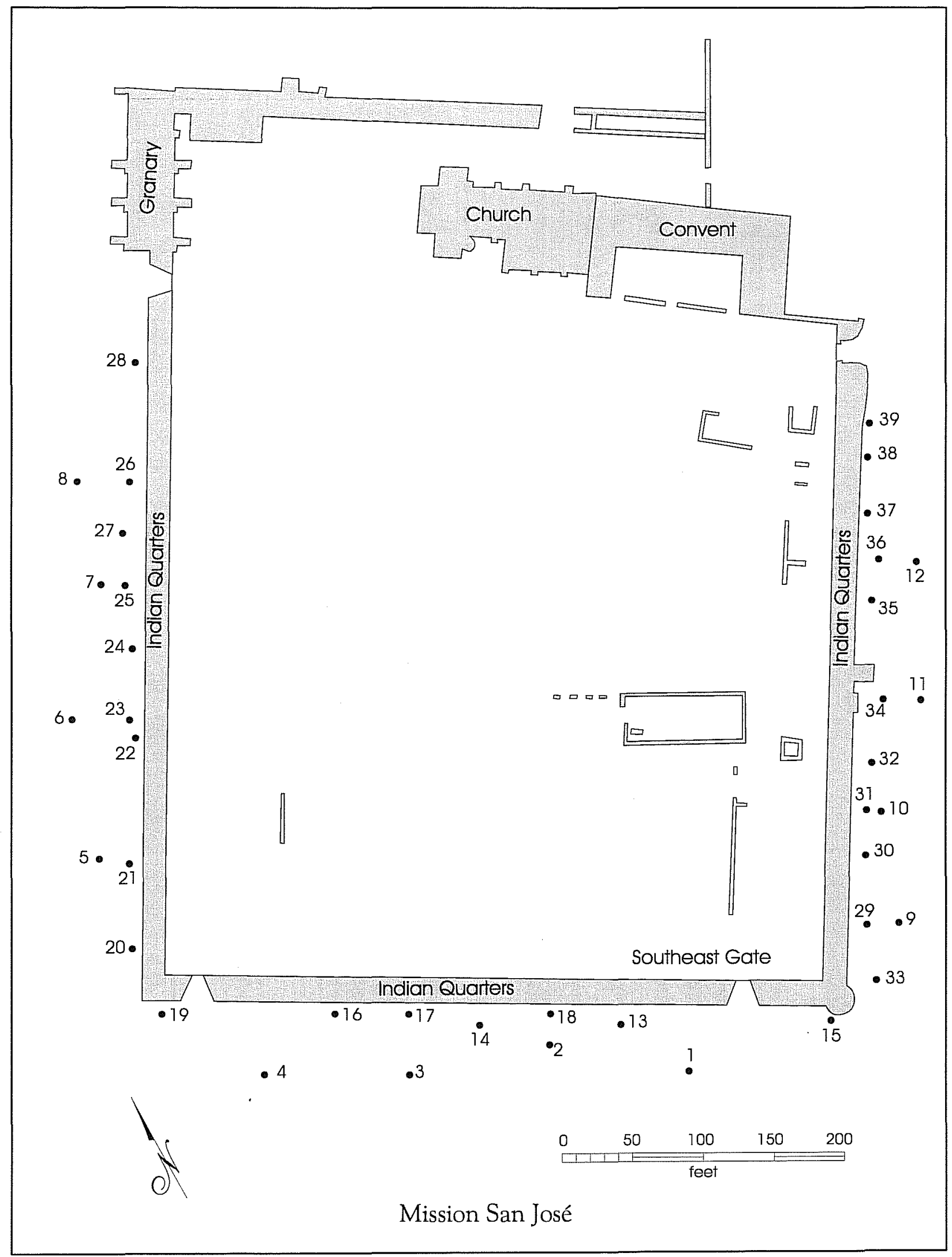

Figure 2. Distribution of shovel tests excavated in October 1997. 


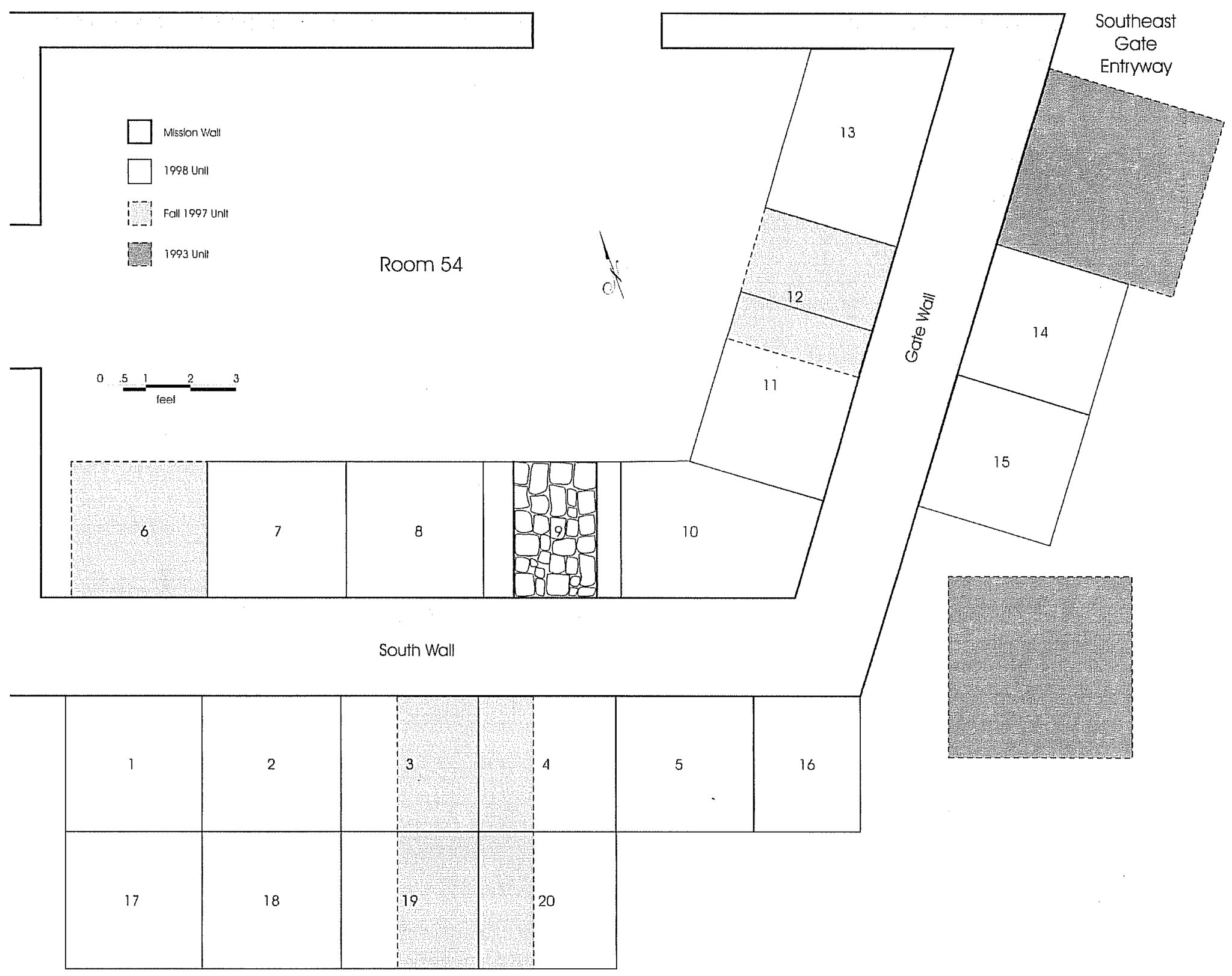

Figure 3. Distribution of excavation units associated with the underpinning work. 
ployees as necessary to allow the construction of segments of the concrete foundation. The goals of the archaeological excavation associated with the underpinning were simple: recover all cultural materials affected by these construction activities; and recover a sample of the colonial foundation.

\section{Methods of Investigation}

\section{The Shovel Testing Project}

Thirty-nine shovel tests were excavated to define the depth, content, and spatial extent of the cultural materials outside of the mission walls (Figure 2). Twenty-eight of the units were located between 9-15 feet from the mission walls. The remaining 11 were placed between 30-50 feet from the walls to determine whether prior grading efforts had removed and used top soil from outlying areas to build the existing grade observed at the time of the fieldwork. All shovel tests were excavated to a depth of 12 inches bs.

Eleven shovel tests (Nrs. 1-4; 13-19) were excavated along the south wall of the mission, and 15 (Nrs. 9-12; 29-39) were excavated along the east wall. The remaining 13 shovel tests were placed along the west wall of the mission. Tables $1-3$ present the distance of each unit from the wall, the natural stratigraphic levels encountered or defined, and the depths at which cultural materials were encountered in these units.

\section{The Underpinning Project}

The underpinning work required the excavation of 20 3'-x-3' units (Figure 3). Eight of these were located in Room 54 along the south (5 units; Nrs. 6, 7, 8, 9, 10) and east (3 units, Nrs. 11, 12, 13) walls of the front room. Of these units, two (Nrs. 6
Table 1. South wall shovel test units, Mission San José

\begin{tabular}{|c|c|c|c|}
\hline ST & $\begin{array}{c}\text { Distance to } \\
\text { Wall }\end{array}$ & $\begin{array}{c}\text { Level(s) } \\
\text { Defined/(Depth) }\end{array}$ & $\begin{array}{c}\text { Beginning Depth of } \\
\text { Cultural Material }\end{array}$ \\
\hline 1 & 50 feet & L1 $\left(0-4^{\prime \prime}\right)$ & surface \\
\hline & & L2 $\left(4-12^{\prime \prime}\right)$ & surface \\
\hline 2 & 30 feet & L1 $\left(0-9^{\prime \prime}\right)$ & sterile \\
\hline & & L2 $\left(9-12^{\prime \prime}\right)$ & sterile \\
\hline 3 & 50 feet & L1 (0-8") & sterile \\
\hline & & L2 $\left(8-12^{\prime \prime}\right)$ & $8^{\prime \prime}$ bs \\
\hline 4 & 30 feet & L1 $\left(0-10^{\prime \prime}\right)$ & sterile \\
\hline & & L2 $\left(10-12^{\prime \prime}\right)$ & 10" bs \\
\hline 13 & 15 feet & L1 $\left(0-12^{\prime \prime}\right)$ & surface \\
\hline 14 & 9 feet & L1 $\left(0-5^{\prime \prime}\right)$ & sterile \\
\hline & & L2 $\left(5-7^{\prime \prime}\right)$ & 5" bs \\
\hline & & L3 $\left(7-12^{\prime \prime}\right)$ & sterile \\
\hline 15 & 9 feet & L1 $\left(0-12^{\prime \prime}\right)$ & surface \\
\hline 16 & 9 feet & L1 $\left(0-12^{\prime \prime}\right)$ & surface \\
\hline 17 & 9 feet & L1 $\left(0-12^{\prime \prime}\right)$ & surface \\
\hline 18 & 9 feet & L1 $\left(0-12^{\prime \prime}\right)$ & surface \\
\hline 19 & 9 feet & L1 $\left(0-12^{\prime \prime}\right)$ & surface \\
\hline
\end{tabular}

Table 2. East wall shovel test units, Mission San José

\begin{tabular}{|c|c|c|c|}
\hline ST & $\begin{array}{c}\text { Distance to } \\
\text { Wall }\end{array}$ & $\begin{array}{c}\text { Level(s) } \\
\text { Defined/(Depth) }\end{array}$ & $\begin{array}{c}\text { Beginning Depth of } \\
\text { Cultural Material }\end{array}$ \\
\hline 9 & 30 feet & L1 (0-12") & surface \\
\hline 10 & 15 feet & L2 (0-12") & surface \\
\hline 11 & 40 feet & L1 (0-9") & surface \\
\hline & & L2 (9-12") & surface \\
\hline 12 & 40 feet & L1 (0-12") & surface \\
\hline 29 & 9 feet & L1 $\left(0-12^{\prime \prime}\right)$ & surface \\
\hline 30 & 9 feet & L1 $\left(0-12^{\prime \prime}\right)$ & surface \\
\hline 31 & 9 feet & L1 $\left(0-12^{\prime \prime}\right)$ & surface \\
\hline 32 & 12 feet & L1 (0-12") & surface \\
\hline 33 & 15 feet & L1 $\left(0-12^{\prime \prime}\right)$ & surface \\
\hline 34 & 15 feet & L1 $\left(0-12^{\prime \prime}\right)$ & surface \\
\hline 35 & 10 feet & L1 $\left(0-12^{\prime \prime}\right)$ & surface \\
\hline 36 & 12 feet & L1 $\left(0-12^{\prime \prime}\right)$ & surface \\
\hline 37 & 9 feet & L1 $\left(0-12^{\prime \prime}\right)$ & surface \\
\hline 38 & 7 feet & L1 $\left(0-4^{\prime \prime}\right)$ & surface \\
\hline & & L2 $\left(4-12^{\prime \prime}\right)$ & surface \\
\hline 39 & 7 feet & L1 $\left(0-12^{\prime \prime}\right)$ & surface \\
\hline
\end{tabular}

and 12) were excavated in the fall of 1997 as part of the San José Wallbase project (Tomka and Fox 1998). Of the remaining six units, two (Nrs. 10 and 13) were slightly larger than $3^{\prime} \times 3^{\prime}$ due to their corner position. 
Table 3. West wall shovel test units, Mission San José

\begin{tabular}{|c|c|c|c|}
\hline ST & $\begin{array}{c}\text { Distance to } \\
\text { Wall }\end{array}$ & $\begin{array}{c}\text { Level(s) } \\
\text { Defined/(Depth) }\end{array}$ & $\begin{array}{c}\text { Beginning Depth of } \\
\text { Cultural Material }\end{array}$ \\
\hline 5 & 30 feet & L1 (0-9") & surface \\
\hline & & L2 $\left(9-12^{\prime \prime}\right)$ & surface \\
\hline 6 & 50 feet & L1 $\left(0-12^{\prime \prime}\right)$ & surface \\
\hline 7 & 30 feet & L1 $\left(0-12^{\prime \prime}\right)$ & surface \\
\hline 8 & 50 feet & L1 $\left(0-12^{\prime \prime}\right)$ & surface \\
\hline 20 & 9 feet & L1 $\left(0-12^{\prime \prime}\right)$ & surface \\
\hline 21 & 9 feet & L1 $\left(0-12^{\prime \prime}\right)$ & surface \\
\hline 22 & 6 feet & L1 $\left(0-12^{\prime \prime}\right)$ & surface \\
\hline 23 & 9 feet & L1 (0-12") & surface \\
\hline 24 & 9 feet & L1 $\left(0-12^{\prime \prime}\right)$ & surface \\
\hline 25 & 15 feet & L1 (0-9") & surface \\
\hline & & L2 $\left(9-12^{\prime \prime}\right)$ & surface \\
\hline 26 & 9 feet & L1 $\left(0-12^{\prime \prime}\right)$ & surface \\
\hline 27 & 15 feet & L1 $\left(0-12^{\prime \prime}\right)$ & surface \\
\hline 28 & 9 feet & L1 $\left(0-12^{\prime \prime}\right)$ & surface \\
\hline
\end{tabular}

In addition, Unit 11 measured only $2^{\prime}$ x $3^{\prime}$ because a portion of it was excavated by Unit 12 .

Twelve units were excavated outside along the mission's south wall and along the west wall of the gate. Of these units, 10 (Nrs. 1-5, 16-20) were excavated along the south wall of the mission, immediately adjacent the corner of the gate, and two (Nrs. 14, 15) were dug along the center of the gate's west wall. Along the south wall, six units (Nrs. 1-5, 16) were positioned immediately against the base of the wall. To allow sufficient access to the wallbase to install steel reinforcement beams, four additional 3'-x-3' units (Nrs. 17-20) were excavated three feet from the wall and contiguous to the westernmost four units. Because during the fall of 1997 , a 3'-x-9' block was excavated immediately under the first canal adjacent the southeast gate, units 3, 4, 19, and 20 were only partial units during the 1998 excavation, as was Unit 16 located immediately adjacent the corner (Figure 3). Only two units (Nrs. 14, 15) were excavated in the center of the west wall of the gate. Two 4'- $x-4$ ' units on either side of these units had been excavated by CAR personnel in 1993 (Tennis 1997:Figure 1) and did not require further archaeological work (Figure 3). These areas were re-excavated by the construction contractor.
The number, location, and approximate size of the test units were all specified by the Scope of Work provided by NPS. Once a series of units was excavated on the inner and outer side of the south wall of Room 54 , four-foot-long alternating segments of the colonial foundation were excavated from under the CWA reconstruction wall. The sequence and location of these foundation removals was agreed upon in consultation with the construction contractor to facilitate the construction of the reinforced concrete foundation without endangering the integrity of the wall. A small segment of the colonial foundation was first removed by CAR personnel to monitor the material content. Because no other cultural materials were encountered except the caliche nodules that constituted the foundation, the excavation of the remainder of the colonial foundation was carried out by the construction contractor in consultation with CAR archaeologists.

To correspond to the drawings in the 1976 report by Roberson and Medlin, measurements during the field work were done in inches and feet. Previous excavations at Mission San José (Tomka and Fox 1998; Tomka and Fox 1999) have established that the heaviest degree of disturbance reaches from surface to a depth of approximately 12 inches. Deposits are less and less disturbed with increasing depth, and the least disturbed colonial materials occur on top of and slightly into the black clay layer that underlies the site. This clay zone begins at a depth of between 22-24 inches bs. This generalized stratigraphy is violated adjacent the interior and exterior bases of the wall. Here, CWA efforts to locate the top of the colonial foundation resulted in trenches paralleling the wall and reaching a depth of between 21-29 inches (Figure 4). The outline of the trench is more notable along the exterior than the interior of the wallbase. The base of the trench could be identified only in one interior unit, Unit 10. In units where the bottom of the CWA trench reached a depth of at least 22 inches bs, intact colonial deposits are no longer present. In the exterior units, the width of the trench ranges from 12-18 inches and often signals the fact that in the excavation units found immediately against the base of the wall, between one-third to one-half of the deposits are 


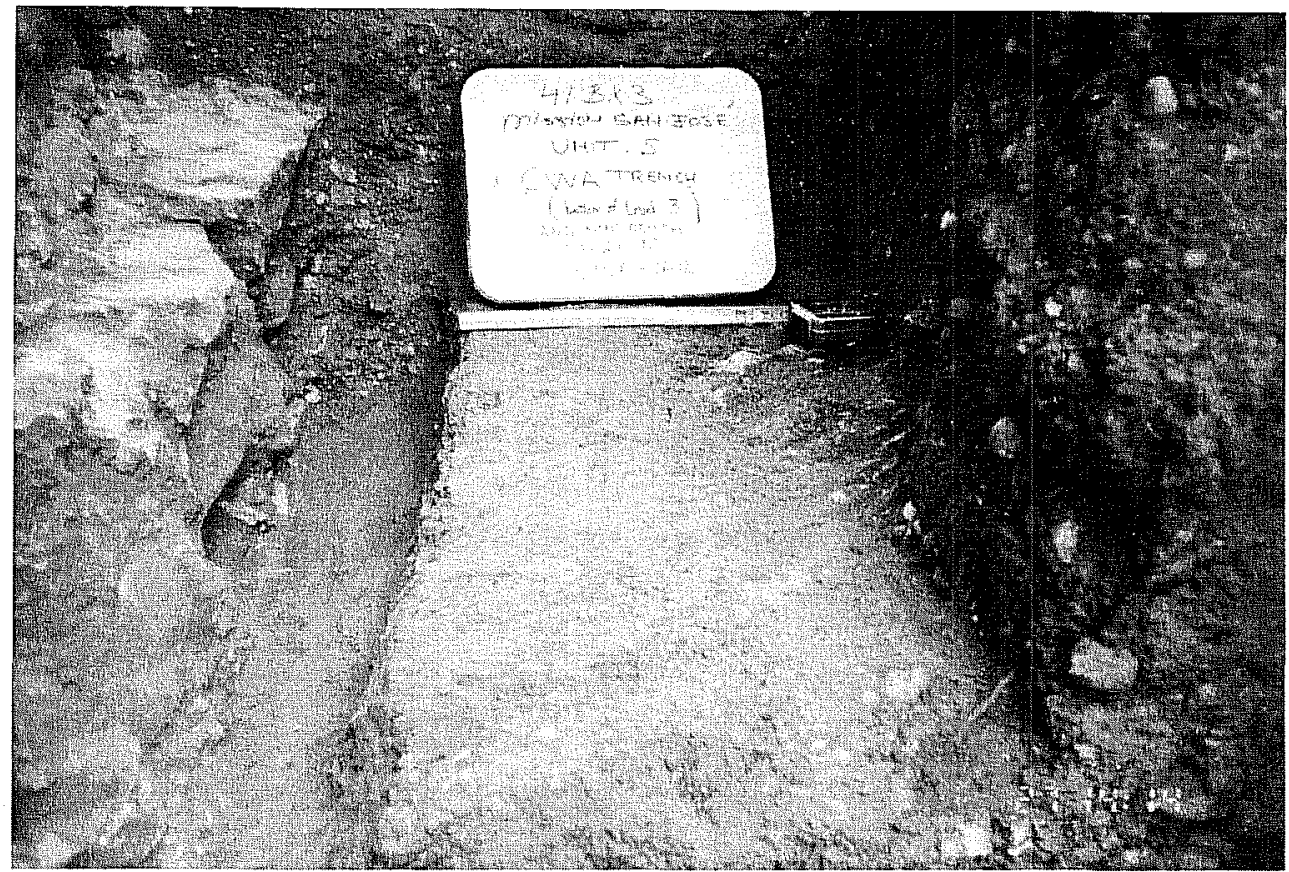

Figure 4. Outline of the exterior CWA trench. Note depth and width away from wall base.

entirely mixed. Normally, south of the CWA trench and in some instances below it, the stratigraphy reflected this generalized pattern.

Because previous excavations (Tomka and Fox 1998; Tomka and Fox 1999) away from the base of the CWA wall were conducted in six-inch levels, to maintain consistency all excavations in units located away from the outside base of the wall (Units 17, 18, 19, 20) were conducted in the same increments (Figure 3). Similarly, all indoor units $(7,8,9,11,13)$ where the outlines of the CWA trench could not be discerned also were excavated in six-inch arbitrary levels.

Units 1-5 and 16, against the exterior base of the mission's south wall, were excavated using a mix of six-inch levels and natural stratigraphy. The top level was always six inches thick and extended from 12-18 inches bs. The next level was excavated to a depth at which the black clay layer could be discerned in the southern half of the units and the edge/outline of the CWA trench was visible in the northern portion. As a result, Level 2 ranged in thickness from 2-4 inches (18-20 inches bs or 18-22 inches bs). Level 3 was excavated in two proveniences. The northern half, the backfill of the CWA trench, was excavated separately, and the depth of this $12-$ 18 -inch wide zone ranged from 2-7 inches. This backfill was assigned the Level 3CWA provenience designation. The southern half of the units, undisturbed by the CWA trench, was always excavated to a depth of 24 inches bs. It was designated as the Level 3Colonial provenience because it consisted of less-disturbed colonial matrix. When the CWA trench did not extend to a depth of 24 inches bs, the excavation of Level 3Colonial was continued across the entire surface of the unit to create a flat, even surface. Level 4 was always a sixinch layer from 24-30 inches bs. At least one selected wall of each unit was profiled and photographed.

A slightly different strategy was employed in excavating Unit 10 , in the southeast corner of the front room of Room 54. Level 1 (12-18 inches bs) in Unit 10 was excavated to a depth of 18 inches bs. Level 2 (18-21 inches bs) was only three inches deep because the CWA trench outline was identified in the southern third of the unit, while an orange-yellow packed surface was present in the northern portion of the unit. Therefore, Level 3 was excavated as two distinct proveniences: the disturbed area (Level 3CWA) and the orange-yellow matrix that was identified as a slightly disturbed colonial living floor (Level 3Colonial). Both the CWA disturbed zone and the colonial living floor ranged from $2-3 \mathrm{~cm}$ in thickness across the unit and was set on black clay. Level $4(24-30 \mathrm{~cm}$ bs) was excavated into the black clay base.

The excavation of Units 14 and 15 against the eastern wall of the gate also differed somewhat from the previous strategy. Prior to the initiation of the excavation of these units, an approximately 6-inch-thick concrete sidewalk had to be removed to gain access to the area. 
To ensure sufficient working area, the sidewalk and the underlying construction-disturbed matrix were removed from the western half of the gate entrance. Once the sidewalk and the underlying rubble were removed, the clean surface from which excavation of Level 1 commenced ranged from 19-21 inches bs. Therefore, in Unit 14 Level 1 extended from 21-27 inches bs into black clay. In Unit 15 a small portion of partially disturbed colonial matrix was revealed in Level 1 (19.5-21 inches bs), while Level 2 extended from 21-27 inches bs.

All soil removed was screened through $1 / 4$-inch mesh. Because previous excavations had established that the upper 12 inches of deposits were highly disturbed both in Room 54 and outside along the walls, prior to the beginning of the excavations the upper 12 inches of topsoil were removed by the construction contractor. Artifacts recovered from all CAR-excavated levels were bagged and returned to the laboratory. Level records were kept on standard CAR forms and a dayto-day narrative of the work was kept by the project archaeologist.

In the laboratory, all artifacts recovered from shovel testing and excavation were washed and cataloged on standard historic artifact forms used by CAR. All artifacts recovered were grouped into the following analytical categories and subcategories: Ceramics (Unglazed Goliad, Unglazed Other, Burnished, Lead Glazed, Tin Glazed, Porcelain, Whiteware, Yellowware, and Stoneware); Household (Diagnostic and Undiagnostic Glass Containers, Tableware,
Kitchenware); Personal (Clothing, Jewelry, Amusements, Personal Objects); Barn/Workshop/Garage; Arms; Construction (Cut and Wire Nails, Other Hardware, Building Materials); Lithics; Faunal Remains (Bone, Shell); and Miscellaneous (Identifiable and Unidentifiable Metal Objects, Other). Analysis of the artifacts included identification and approximate dating of the ceramics and glass and identification of the faunal material. A FileMaker database was used to create a permanent catalog and Excel spreadsheets were employed in data analysis. All field photographs, artifacts, and records are curated at CAR.

\section{Results of the Excavations}

Steve A. Tomka and Anne A. Fox

\section{The Shovel Testing Project}

\section{South Wall}

Eleven shovel tests (Nrs. 1-4; 13-19) were excavated along the south wall of the mission (Figure 2). A total of 375 artifacts was recovered. Table 4 presents the artifact categories identified. Household items, consisting mainly of clear glass, miscellaneous unidentified metal fragments, and animal bones constitute the bulk of the materials. Ceramics are scarce with the exception of ST 3. Table 5 indicates that post-colo-

Table 4. Artifacts from south wall shovel test units, Mission San José

\begin{tabular}{|c|c|c|c|c|c|c|r|r|r|}
\hline ST & Ceramics & Household & Personal & $\begin{array}{c}\text { Construction } \\
\text { Materials }\end{array}$ & Misc. Metal & Plastics & Lithics & Bone & Totals \\
\hline 1 & 2 & 20 & & 14 & 14 & & & 10 & 60 \\
\hline 3 & 25 & 25 & 1 & 7 & 8 & & 1 & 31 & 98 \\
\hline 4 & 5 & 13 & & 7 & 1 & & & 26 \\
\hline 14 & & & & 1 & & 1 & & 2 \\
\hline 15 & & 2 & & 3 & 1 & & & 2 & 8 \\
\hline 16 & 2 & 17 & & & 2 & 1 & & 1 & 23 \\
\hline 17 & 6 & 9 & & 3 & 1 & & & 55 & 74 \\
\hline 18 & 2 & 8 & & 8 & & & & 10 & 28 \\
\hline 19 & 8 & 18 & & 10 & 15 & & & 5 & 56 \\
\hline Totals & 50 & 112 & 1 & 53 & 42 & 2 & 1 & 114 & 375 \\
\hline
\end{tabular}

* Unit 2 was sterile; materials from Unit 13 were lost. 
Table 5. Ceramics from south wall shovel test units, Mission San José

\begin{tabular}{|r|c|c|c|c|c|r|r|}
\hline \multicolumn{1}{|c|}{ ST } & Unglazed & $\begin{array}{c}\text { Lead- } \\
\text { Glazed }\end{array}$ & $\begin{array}{c}\text { Tin- } \\
\text { Glazed }\end{array}$ & Whiteware & $\begin{array}{c}\text { European } \\
\text { Porcelain }\end{array}$ & Stonewares & Totals \\
\hline 1 & & & & 2 & & & 2 \\
\hline 3 & 7 & 2 & 1 & 13 & 1 & 1 & 25 \\
\hline 4 & & & & 5 & & & 5 \\
\hline 16 & & & & 2 & & & 2 \\
\hline 17 & 2 & 1 & & 3 & & & 6 \\
\hline 18 & 2 & & & & & & 2 \\
\hline 19 & & & & 7 & 1 & & 8 \\
\hline Totals & 11 & 3 & 1 & 32 & 2 & 1 & 50 \\
\hline
\end{tabular}

shovel tests, it is suggested that less-disturbed deposits containing a greater proportion of pre1800 s or colonial materials may be found along the south wall of the mission but only at a depth greater than 12 inches bs.

\section{East Wall}

Fifteen shovel tests (Nrs. 9-12; 29-39) were excavated along the east wall of the mission. Artifacts numbering 1,342 were recovered. Table 6 presents the broad artifact categories identified in the materials recovered. Animal bone and household items (consisting mostly of clear glass pieces, ceramics, and miscellaneous unidentified metal) are the most common artifacts. ST 11 yielded large numbers of both bones and ceramics. Metal fragments are common along the middle portion of the wall. Table 7 indicates that, in contrast to the south wall of the mission, pre-1800s (colonial) period specimens (e.g., unglazed, lead-glazed, and tin-glazed) dominate the collection. Significantly, a large majority (66 percent) derive from one unit ( ST 11). Post-1800s (post-colonial) ceramics, and particularly whitewares, are surprisingly scarce but present.

Table 6. Artifacts from east wall shovel test units, Mission San José

\begin{tabular}{|r|c|c|c|c|c|c|c|c|r|r|r|}
\hline ST & Ceramics & Household & Personal & $\begin{array}{c}\text { Barn/Workshop/ } \\
\text { Garage }\end{array}$ & $\begin{array}{c}\text { Construction } \\
\text { Materials }\end{array}$ & $\begin{array}{c}\text { Misc. } \\
\text { Metal }\end{array}$ & Plastics & Lithics & Bone & Shell & Totals \\
\hline 9 & 1 & 16 & & & 4 & 1 & & & 1 & & 23 \\
\hline 10 & 2 & 3 & & & & & & & 11 & & 16 \\
\hline 11 & 66 & 10 & & 1 & 2 & 6 & 5 & 2 & 635 & 4 & 731 \\
\hline 12 & 9 & 29 & & & 8 & 2 & 3 & 2 & 15 & & 68 \\
\hline 29 & 2 & 12 & & 1 & & & & & 9 & & 24 \\
\hline 30 & 2 & 21 & & & 2 & 1 & & & 35 & & 61 \\
\hline 31 & 6 & 2 & 1 & & 4 & & & 1 & 16 & & 30 \\
\hline 32 & 5 & 12 & & & & 3 & & & 24 & 1 & 45 \\
\hline 33 & 5 & 18 & & & 3 & 15 & & & 18 & 1 & 60 \\
\hline 34 & 4 & 18 & & 1 & 11 & 3 & & & 10 & 1 & 48 \\
\hline 35 & 16 & 29 & & 2 & 4 & 57 & & 1 & 13 & & 122 \\
\hline 36 & 4 & 12 & 1 & & 3 & 2 & & & 34 & & 56 \\
\hline 37 & 3 & 7 & & & 1 & & & & 17 & 28 \\
\hline 38 & & 7 & & & 4 & 4 & & & & & 15 \\
\hline 39 & 1 & 10 & & & 2 & 1 & & & 1 & & 15 \\
\hline Totals & 126 & 206 & 2 & 5 & 48 & 95 & 8 & 6 & 839 & 7 & 1342 \\
\hline
\end{tabular}


Table 7. Ceramics from east wall shovel test units, Mission San José

\begin{tabular}{|r|c|c|c|c|c|r|r|}
\hline \multicolumn{1}{|c|}{ ST } & Unglazed & $\begin{array}{c}\text { Lead- } \\
\text { Glazed }\end{array}$ & $\begin{array}{c}\text { Tin- } \\
\text { Glazed }\end{array}$ & Whiteware & $\begin{array}{c}\text { European } \\
\text { Porcelain }\end{array}$ & $\begin{array}{c}\text { Other } \\
\text { Wares }\end{array}$ & Totals \\
\hline 9 & & & & & & 1 & 1 \\
\hline 10 & 2 & & & & & & 2 \\
\hline 11 & 60 & 2 & 3 & 1 & & & 66 \\
\hline 12 & 5 & 1 & & 3 & & & 9 \\
\hline 29 & 1 & & 1 & & & & 2 \\
\hline 30 & 1 & 1 & & & & & 2 \\
\hline 31 & 5 & 1 & & & & & 6 \\
\hline 32 & 4 & & & 1 & & & 5 \\
\hline 33 & & & & 2 & 3 & & 5 \\
\hline 34 & & & 1 & 3 & & & 4 \\
\hline 35 & 7 & 5 & & 2 & 2 & & 16 \\
\hline 36 & 1 & 2 & 1 & & & & 4 \\
\hline 37 & 1 & & & 1 & 1 & & 3 \\
\hline 39 & & & & 1 & & & 1 \\
\hline Totals & 87 & 12 & 6 & 14 & 6 & 1 & 126 \\
\hline
\end{tabular}

The relative abundance of colonial-period ceramics as well as animal bone in ST 11 at a distance of 40 feet from the wall of the mission suggests the possibility that this may be the location of a midden deposit associated with the Indian Quarters found along the eastern margin of the mission. The materials observed in the remaining shovel tests indicate that the 12 inches sampled represent a relatively mixed deposit. This is particularly true of the deposits found along the southern half of the east wall and within 15 feet of the wallbase. Deposits from as far as $65-85$ feet from the wall appear to have been bladed and pushed against the base of the wall to provide a significant grade. As a result artifacts found in the upper 12 inches of matrix along the southern portion and within 15 feet of the wall are in a secondary disturbed depositional context. Yet, the likelihood is high that less-disturbed cultural deposits dating to the colonial period are found near the present surface at a distance of some 65-85 feet from the wall (the borrow area). Such significant disturbances are not evident along the northern half of the East Wall. Here much of the cultural material found within the top 12 inches consists of mixed late-nineteenth and twentieth-century remains that appear to have been dispersed, and in some instances pushed against the wallbase, at the time structures and trash dumps existing in the vicinity were leveled. These materials again represent secondary deposits although the depth of the disturbance from former leveling activities might have been less than in the case of the grading activities along the southern portion.

\section{West Wall}

Thirteen shovel tests (Nrs. 5-8; 20-28) were excavated along the west wall of the mission. Artifacts numbering 1,107 were recovered. Table 8 presents the broad artifact categories identified in the materials recovered. Animal bone fragments constitute the most common artifacts, followed by household items, mainly consisting of clear glass, ceramics, and miscellaneous unidentified metal. Bone is particularly common in ST 7, while ceramics are most abundant in ST 6, 24, and 25. Table 9 indicates that post-1800s (post-colonial) specimens dominate the small collection of ceramics. Pre-1800s (colonial) ceramics are scarce but present.

The presence of colonial-period ceramics coupled with numerous post-1800s specimens suggests mixed deposits dominated by relatively recent artifacts. Clear indication of the mixed nature of the deposits is evident along the central portion of the wall in the vicinity of a moderate artificial platform built to provide a raised but level surface for two large air conditioning 
Table 8. Artifacts from west wall shovel test units, Mission San José

\begin{tabular}{|r|c|c|c|c|c|c|c|c|r|r|r|}
\hline ST & Ceramics & Household & Personal & $\begin{array}{c}\text { Barn/Workshop/ } \\
\text { Garage }\end{array}$ & $\begin{array}{c}\text { Construction } \\
\text { Materials }\end{array}$ & $\begin{array}{c}\text { Misc. } \\
\text { Metal }\end{array}$ & Plastics & Lithics & Bone & Shell & Totals \\
\hline 5 & 5 & 20 & & & 16 & 13 & 1 & & 23 & & 78 \\
\hline 6 & 20 & 25 & 1 & 3 & 5 & & 5 & & 3 & & 62 \\
\hline 7 & 20 & 10 & & 1 & 1 & 4 & & 1 & 168 & 1 & 206 \\
\hline 8 & 14 & 19 & 2 & & 4 & 53 & & 3 & 63 & 158 \\
\hline 20 & 1 & 8 & & & 2 & & & & 216 & & 227 \\
\hline 21 & 4 & 18 & & & & & & & 53 & & 75 \\
\hline 22 & 1 & 5 & & & 8 & & & & 1 & & 15 \\
\hline 23 & 3 & 2 & & & & & & & 50 & & 55 \\
\hline 24 & 19 & 2 & & & 43 & & & 2 & 40 & & 106 \\
\hline 25 & 21 & 10 & & 1 & 1 & 4 & & 1 & 17 & 2 & 57 \\
\hline 26 & 4 & 1 & & 1 & 2 & & & & & & 8 \\
\hline 27 & 13 & 15 & & & 3 & 5 & 1 & & 16 & & 53 \\
\hline 28 & 1 & 2 & & & 1 & & & & 3 & 7 \\
\hline Totals & 126 & 137 & 3 & 6 & 86 & 79 & 7 & 7 & 653 & 3 & 1107 \\
\hline
\end{tabular}

Table 9. Ceramics from west wall shovel test units, Mission San José

\begin{tabular}{|r|r|r|r|r|r|r|r|r|}
\hline ST & Unglazed & $\begin{array}{r}\text { Lead- } \\
\text { Glazed }\end{array}$ & $\begin{array}{c}\text { Tin- } \\
\text { Glazed }\end{array}$ & $\begin{array}{c}\text { White- } \\
\text { ware }\end{array}$ & $\begin{array}{c}\text { Yellow } \\
\text { wares }\end{array}$ & $\begin{array}{c}\text { European } \\
\text { Porcelain }\end{array}$ & $\begin{array}{c}\text { Stone- } \\
\text { wares }\end{array}$ & Totals \\
\hline 5 & 2 & 1 & & 2 & & & & 5 \\
\hline 6 & 1 & 2 & 2 & 8 & 1 & 5 & 1 & 20 \\
\hline 7 & 7 & 2 & 4 & 7 & & & & 20 \\
\hline 8 & 1 & 2 & & 10 & & & 1 & 14 \\
\hline 20 & & & & 1 & & & & 1 \\
\hline 21 & 1 & & & 3 & & & & 4 \\
\hline 22 & & 1 & & & & & & 1 \\
\hline 23 & 1 & & & 2 & & & & 3 \\
\hline 24 & 10 & 3 & 3 & 2 & & & 1 & 19 \\
\hline 25 & 7 & 7 & 4 & 3 & & & & 21 \\
\hline 26 & 1 & & & 3 & & & & 4 \\
\hline 27 & 1 & & 1 & 10 & & 1 & & 13 \\
\hline 28 & & & & 1 & & & & 1 \\
\hline Totals & 32 & 18 & 14 & 52 & 1 & 6 & 3 & 126 \\
\hline
\end{tabular}

units. As indicated by the quantity of clear glass and whiteware ceramics found on the surface, this platform was apparently constructed by mounding dirt scraped from as far as $20-30$ feet from the surrounding area. It also implies that less-disturbed cultural materials may be found near the present ground surface in these more outlying areas in the vicinity of the platform. The presence of a large quantity of animal bone recovered from ST 7, in conjunction with the possibility that a midden, associated with the mission, may have existed in the vicinity (Schuetz 1970), sug- gest that subsurface disturbance extending more than nine inches below the present surface in the vicinity of the unit might disturb cultural materials of potential significance.

Based on more extensive and deeper excavations (Units 12 and 15) conducted by CAR personnel in September 1997 (Tomka and Fox 1998), in conjunction with the data from these 13 shovel tests, it is suggested that less disturbed deposits containing a greater proportion of pre-1800s or colonial materials may be 
found along the west wall of the mission but only at a depth greater than 12 inches bs. The large quantity of animal bones and the presence of colonial ceramics in ST 7 concurs with Schuetz's (1970) observation that a colonial midden may be found in the vicinity.

\section{The Underpinning Project}

\section{Units in Room 54 (7-11, 13)}

Of the eight units excavated along the interior south and east walls of this room, two-Units 6 and 12 were excavated in the fall of 1997

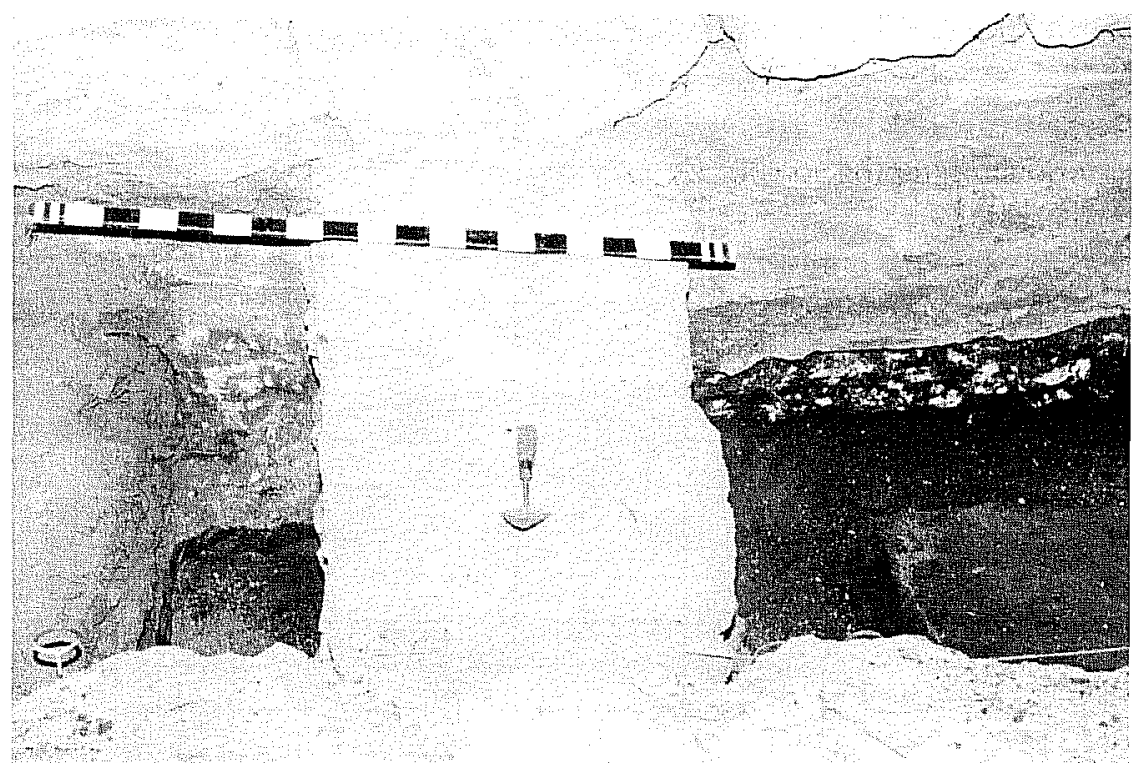

Figure 5. CWA foundation running perpendicular to south wall of Indian Quarters in Room 54.

(Figure 3). Of the remaining six units, four (Units 7 , 8,9 , and 10) were located along the interior south wall while two (Units 11 and 13) were along the east wall. The artifacts of only those units excavated during the present underpinning project will be considered in the following discussion.

Based on the considerable disturbance observed during previous excavations in Room 54, at the recommendation of the project archaeologist, the upper 12 inches of highly disturbed matrix was removed by the construction contractor's employees prior to the initiation of the archaeological excavations in all of the interior units excavated during this project. During the monitoring of this activity it was noted that much of this matrix was heavily disturbed containing loose sandy loam, gravels, and CWA mortar fragments. This disturbed gray sandy loam continued to a depth of 24 inches bs in Units 7 and 8 . The matrix was relatively loose and contained chunks of sandstone and caliche gravels. It came in contact with the black clay substrate that underlies all cultural de-

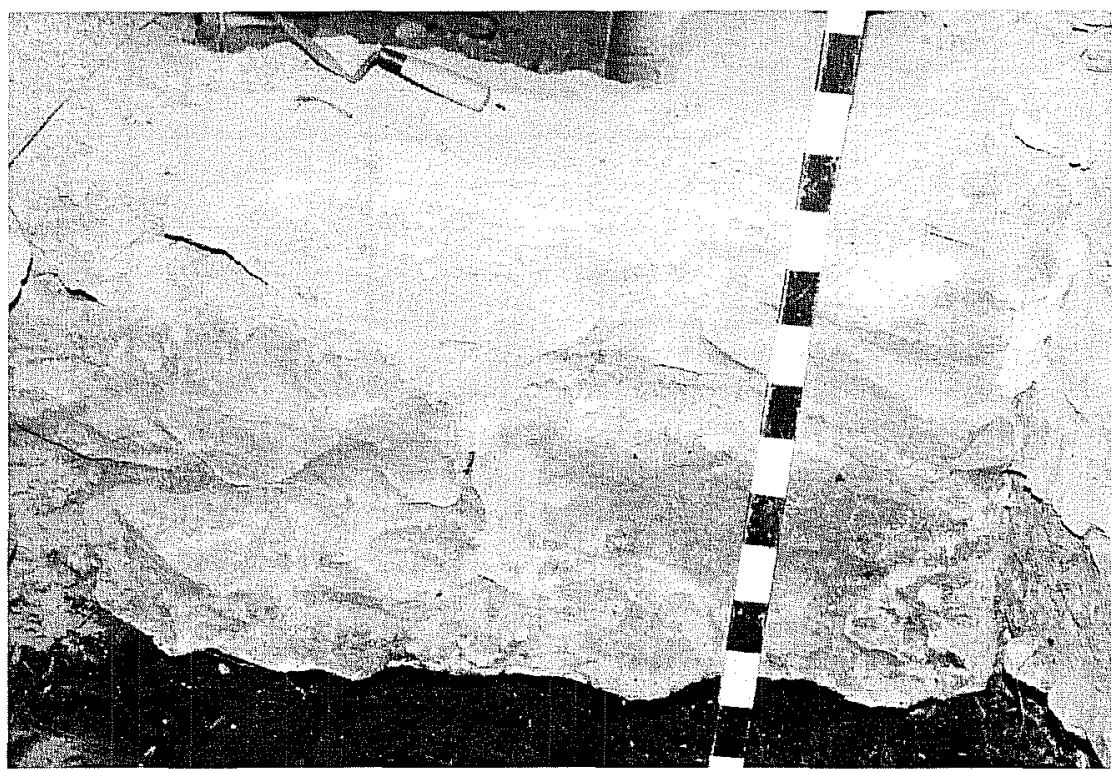

Figure 6. Base of CWA foundation and south wall of Indian Quarters in Room 54. posits at the mission at 24 inches bs. The last level (Level 3, 24-30 inches bs) in these two units was excavated into this black clay. The top of the black clay was relatively rich in artifacts but counts decreased dramatically below the top 2-3 inches.

At a depth of 14 inches bs, the excavation of Unit 9 revealed a foundation oriented perpendicular to the back wall of the room (Figure 5). The foundation was 


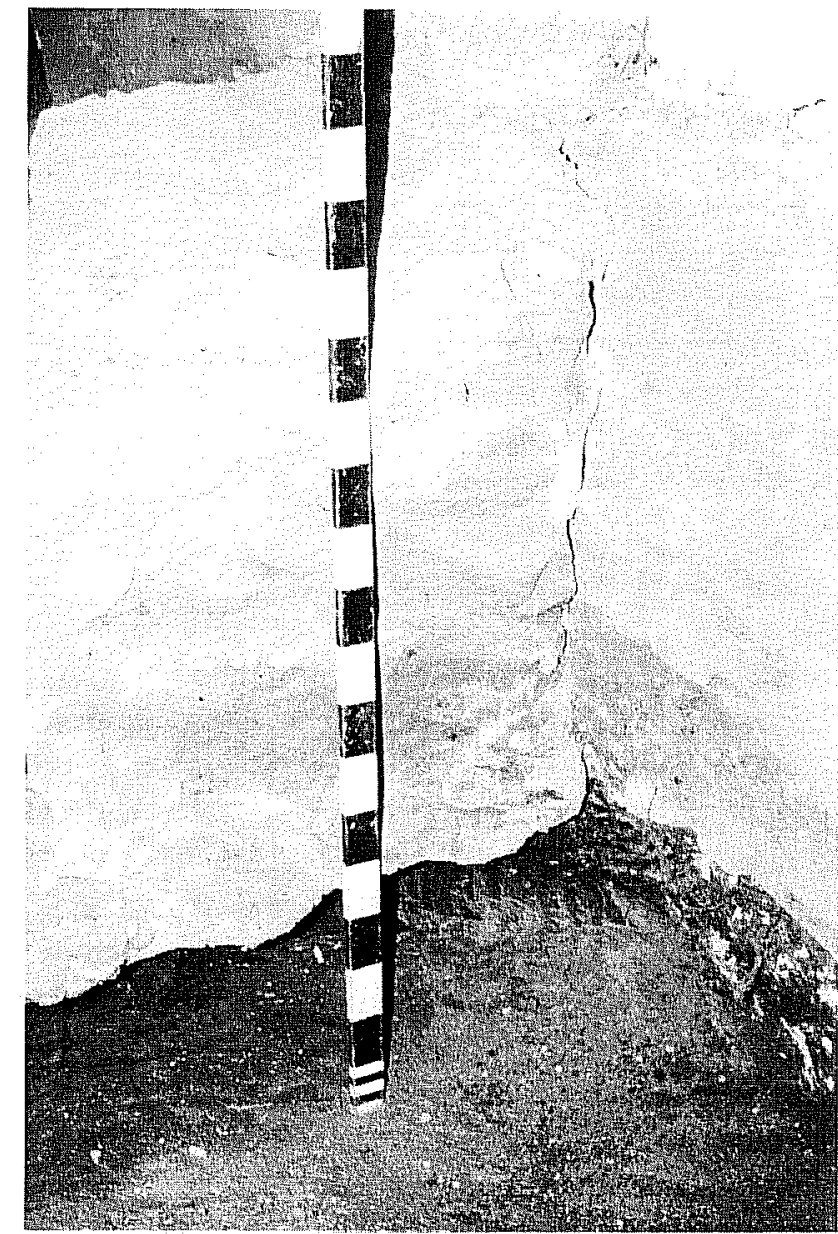

Figure 7. Contact between CWA foundation and south wall of Indian Quarters. Note the lack of jointing between the two.

composed of sandstone and limestone cobbles in Portland cement mortar. The base of the wall extended to a depth of 36 inches bs, matching the depth of the colonial foundation of the outside wall (Figure 6). However, it had no colonial foundation at its base and it abutted the south wall rather than adjoining it (Figure 7). Given these observations, the foundation dates to the time of the CWA reconstruction and may represent an earlier attempt at constructing a gate foundation prior to the existing gate configuration. If so, the previously intended gate walls would have been perpendicular to the south wall rather than tangential, at least based on the three-foot section of the foundation revealed in Unit 9. The foundation is only four feet from the inside corner of the room and the present inside corner of the southeast gate. Alternatively, the foundation may have been intended for an inside wall. However, both its width (21.5 inches) and its height $(95 \mathrm{~cm})$ suggest that it would have been much too massive for such a purpose. The three-foot section of the foundation uncovered in Unit 9 was removed prior to the conception of the underpinning work.

Artifacts totaling 4,126 were recovered in the units excavated within Room 54 (Table 10). The largest numbers came from Units 7,8 , and 10 , while the smallest numbers were recovered from Unit 9 . The low artifact recovery in Unit 9 is due to the CWA foundation that took up most of the unit. Faunal remains, metal fragments, household items, and ceramics constitute the bulk of the artifacts. Construction-related artifacts occur in moderate numbers, while chipped lithic artifacts are scarce. In general, the frequencies of all artifact categories decrease with depth, with the highest numbers occurring in the upper two excavation levels (Table 11).

The excavation of Level 1 (12-18 inches bs) in Unit 10 revealed CWA-disturbed deposits. One example of this disturbance is Feature 1 uncovered in the southcentral portion of the unit. Feature 1 consists of a

Table 10. Artifacts from Room 54 interior units, by excavation unit

\begin{tabular}{|r|c|c|c|c|c|c|c|c|r|r|r|}
\hline Unit & Ceramic & $\begin{array}{c}\text { House- } \\
\text { hold }\end{array}$ & Personal & $\begin{array}{c}\text { Barn/Workshop/ } \\
\text { Garage }\end{array}$ & Arms & Construction & Lithics & Bone & Shell & Misc. & Metal \\
\hline 7 & 84 & 174 & 1 & 1 & 1 & 37 & 3 & 392 & 3 & 232 & 928 \\
\hline 8 & 93 & 148 & & & 1 & 66 & 7 & 329 & 9 & 182 & 835 \\
\hline 9 & 25 & 26 & 1 & & & 19 & 1 & 166 & & 33 & 271 \\
\hline 10 & 68 & 70 & & & & 47 & 6 & 544 & 3 & 79 & 817 \\
\hline 11 & 30 & 33 & 1 & & & 38 & 6 & 368 & 11 & 59 & 546 \\
\hline 13 & 36 & 26 & 1 & & & 3 & 4 & 649 & 3 & 7 & 729 \\
\hline Totals & 336 & 477 & 4 & 1 & 2 & 210 & 27 & 2448 & 29 & 592 & 4126 \\
\hline
\end{tabular}


Table 11. Artifacts from Room 54 interior units, by level

\begin{tabular}{|c|c|c|c|c|c|c|c|c|c|c|c|}
\hline Level & Ceramic & $\begin{array}{c}\text { House- } \\
\text { hold }\end{array}$ & Personal & $\begin{array}{c}\text { Barn/Workshop/ } \\
\text { Garage }\end{array}$ & Arms & $\begin{array}{c}\begin{array}{c}\text { Con- } \\
\text { struction }\end{array} \\
\end{array}$ & Lithics & Bone & Shell & $\begin{array}{l}\text { Misc. } \\
\text { Metal }\end{array}$ & Totals \\
\hline 1 & 120 & 337 & 2 & 1 & 1 & 119 & 9 & 995 & 12 & 458 & 2054 \\
\hline 2 & 138 & 131 & 1 & & 1 & 75 & 14 & 758 & 13 & 111 & 1242 \\
\hline $3+3 \mathrm{cwa}$ & 48 & 7 & & & & 14 & 3 & 557 & & 22 & 651 \\
\hline $3 \operatorname{csur}(\mathrm{U} 10)$ & 4 & & & & & & 1 & 7 & & & 12 \\
\hline 4 & 23 & 2 & 1 & 1 & & 2 & & 101 & 4 & 1 & 135 \\
\hline 5 & 3 & & & & & & & 30 & & & 33 \\
\hline Total & 336 & 477 & 4 & 2 & 2 & 210 & 27 & 2448 & 29 & 592 & 4127 \\
\hline
\end{tabular}

*3cwa combined with other Level 3 artifacts

3 csur (U10)=Level 3 colonial surface in Unit 10

cluster of limestone and sandstone cobbles arranged in a circular pattern (Figure 8). One of the larger tabular pieces was set on its edge (see Figure 8, foreground). The soil within this circular cluster was somewhat lighter than the surrounding matrix. A threeinch diameter circular darker stain could be seen in the center of the area. Subsequent excavation showed the hole to be only two inches deep. Based in part on its location within a disturbed context, examinations of historic photographs showing the CWA construction of the mission walls, and the morphology of the feature, it was decided that the feature may have represented the shorings for one of the feet of the scaffoldings erected along the wall.

Level 2 (18-21 inches bs) in Unit 10 revealed that the CWA reconstructionrelated disturbance continued to a depth of between 21-22 inches bs in the southern half of the unit. Our excavations showed that the trench excavated along the inside of the mission wall extended just below the top of the colonial foundation and into the black clay substrate. However, this trench appears to have disturbed only the southern and eastern 1524 inches of the unit. An orangish-yellow surface was still present in the northcentral portion of the unit at a depth varying between 19-21 inches bs. In the north-central portion of the unit, where it was well preserved, the surface was hard packed and reminiscent of plaster (Figure 9). In areas where the hard cap has been removed by disturbance, the matrix retained the same color but it was very powdery and loose. Only one plastered surface could be discerned in the unit, suggesting a single flooring event. However, it is not unlikely that other floors may have been removed by CWA disturbance.

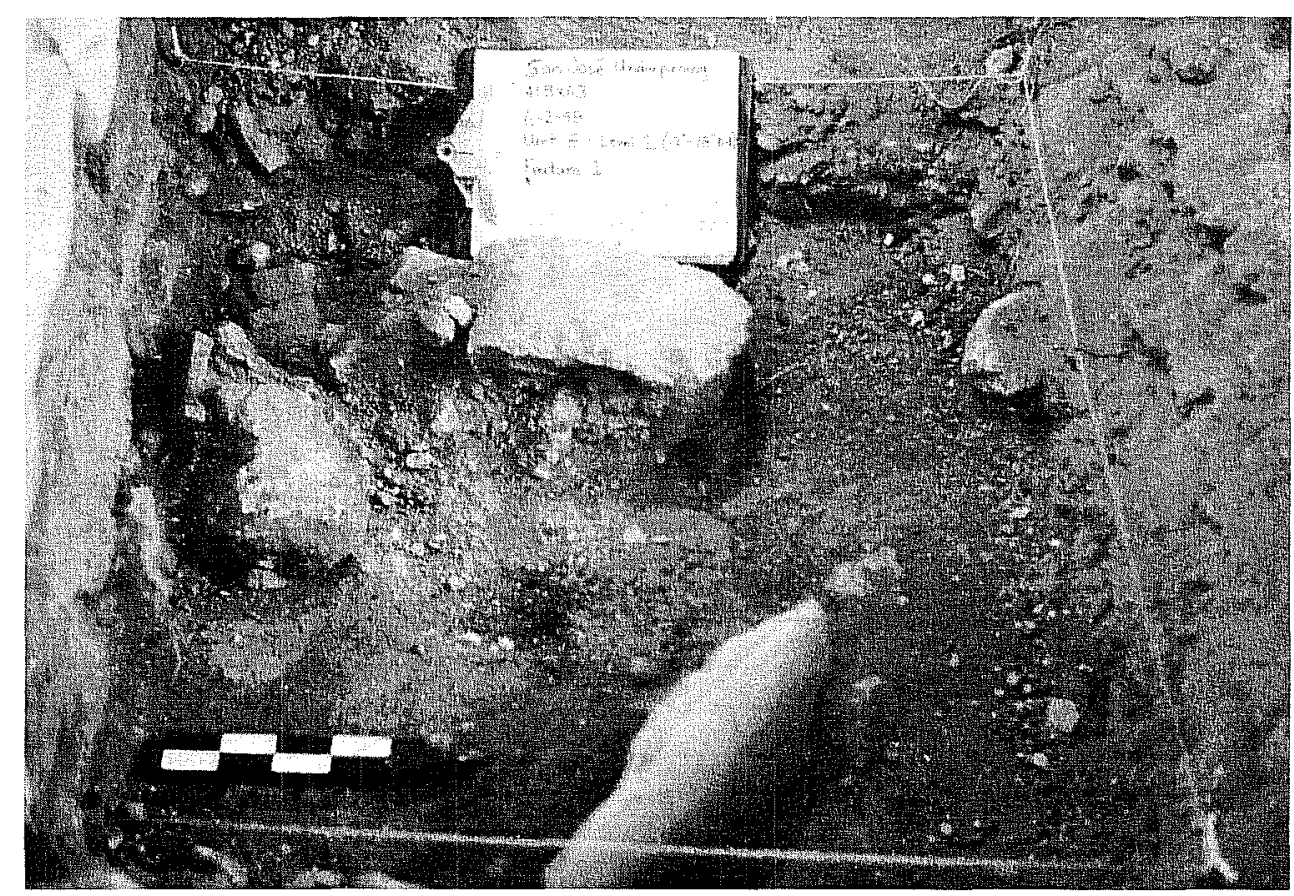

Figure 8. Feature 1, foot support rocks used to stabilize CWA construction scaffolding along inside of Indian Quarters south wall. 


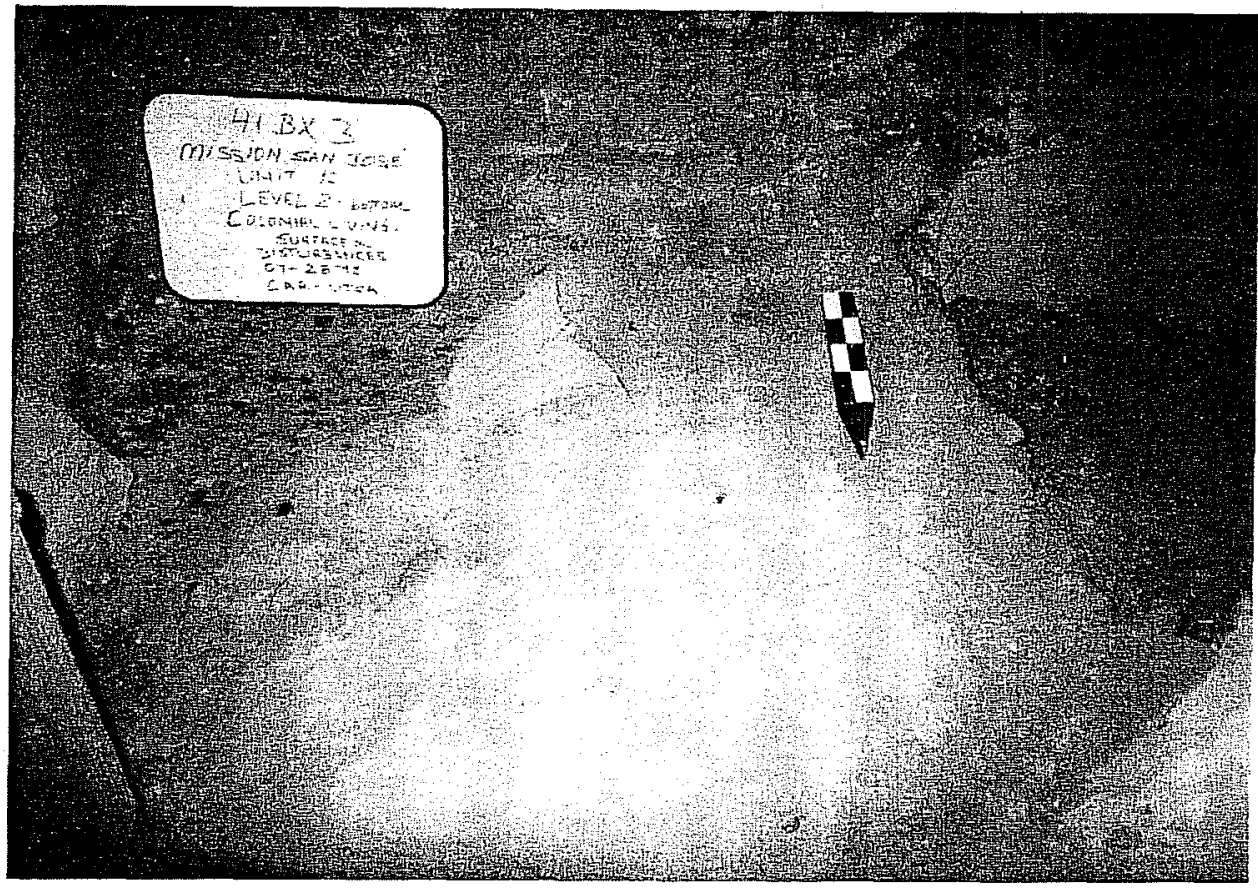

Figure 9. Close-up of colonial living surface remnant in Room 54, Unit 10.
Levels 4 (23-24 inches bs) and 5 (24-30 inches bs) in Unit 10 were excavated in the black clay subsoil. With the exception of a small number of bone fragments encountered in the higher level, no other artifacts were found in these levels.

Remnants of the plastered floor encountered in Unit 10 were also encountered in Units 11 and 13, at a depth of 21.5 inches bs. In addition, Unit 12, excavated in the fall of 1997, also revealed the powdery orangish-yellow matrix in Level 4 (18-24 inches bs) at a depth of between 20.5-22 inches bs particularly evident in the western half of the unit (Field notes from excavation, curated at CAR). This surface was relatively powdery and less well packed suggesting its top portion had been removed by CWA disturbance.

The breakdown of ceramic types by unit recovered within Room 54 indicates that all units contained both colonial (unglazed, lead-glazed, and tin-glazed) and post colonial (whitewares, yellowwares, Chinese and European porcelain, and stonewares) ceramics (Table 12). Although Levels 1-2 (12-24 inches bs) appear, based on ceramic types, to be the most mixed, even Level 3 contains some indication of disturbance (whiteware and porcelain fragments). Deeper levels including the colonial surface in Unit 10 contained only unglazed specimens (Table 13).

Table 12. Ceramic types by unit recovered from Room 54

\begin{tabular}{|r|c|c|c|c|c|c|c|r|r|}
\hline \multicolumn{1}{|c|}{ Unit } & Unglazed & $\begin{array}{c}\text { Lead- } \\
\text { Glazed }\end{array}$ & $\begin{array}{c}\text { Tin- } \\
\text { Glazed }\end{array}$ & Whitewares & Yellowware & $\begin{array}{c}\text { Chinese } \\
\text { Porcelain }\end{array}$ & $\begin{array}{c}\text { European } \\
\text { Porcelain }\end{array}$ & Stonewares & Totals \\
\hline 7 & 54 & 3 & 1 & 12 & & & 1 & 13 & 84 \\
\hline 8 & 35 & 10 & 1 & 23 & 2 & 1 & & 21 & 93 \\
\hline 9 & 15 & 1 & & 8 & & & 1 & & 25 \\
\hline 10 & 50 & 4 & 1 & 11 & 1 & & 1 & & 68 \\
\hline 11 & 14 & 6 & 2 & 7 & & & & 1 & 30 \\
\hline 13 & 34 & 1 & & 1 & & & & & 36 \\
\hline Total & 202 & 25 & 5 & 62 & 3 & 1 & 3 & 35 & 336 \\
\hline
\end{tabular}


Table 13. Ceramic types by level recovered from Room 54

\begin{tabular}{|r|c|c|c|c|c|c|c|r|r|}
\hline \multicolumn{1}{|c|}{ Level } & Unglazed & $\begin{array}{c}\text { Lead- } \\
\text { Glazed }\end{array}$ & $\begin{array}{c}\text { Tin- } \\
\text { Glazed }\end{array}$ & Whitewares & Yellowware & $\begin{array}{c}\text { Chinese } \\
\text { Porcelain }\end{array}$ & $\begin{array}{c}\text { European } \\
\text { Porcelain }\end{array}$ & Stonewares & Totals \\
\hline 1 & 45 & 14 & 1 & 46 & 2 & & 2 & 10 & 120 \\
\hline 2 & 83 & 10 & 3 & 15 & 1 & 1 & & 25 & 138 \\
\hline 3 & 44 & 1 & 1 & 1 & & & 1 & & 48 \\
\hline 3 colonial & 4 & & & & & & & & 4 \\
\hline 4 & 23 & & & & & & & & 23 \\
\hline 5 & 3 & & & & & & & & 3 \\
\hline Total & 202 & 25 & 5 & 62 & 3 & 1 & 3 & 35 & 336 \\
\hline
\end{tabular}

\section{Units along the South Wall of the Mission}

Ten units were excavated outside along the mission's south wall (Nrs. 1-5, 16-20), immediately adjacent the corner of the gate (Figure 3). Six units (Nrs. 1-5, 16) were positioned immediately against the base of the wall. Four additional $3^{\prime}-\mathrm{x}-3^{\prime}$ units (Nrs. 17-20) were excavated three feet from the wall and contiguous with the westernmost four units. Because during the fall of 1997 (Tomka and Fox 1998: Figure 3), a 3'$\mathrm{x}-9$ ' block was excavated immediately under the first canal adjacent the southeast gate, units $3,4,19$, and 20 . were only partial units during the 1998 excavation, as was Unit 16 located immediately adjacent the corner (Figure 3).

Artifacts totaling 7,027 were recovered in the ten units excavated along the south wall (Table 14). The largest numbers came from Units 5 and 18, while the smallest numbers were recovered from two partial units (Units 3 and 19). Faunal remains, miscellaneous metal fragments, ceramics, and household items constitute the bulk of the artifacts. Construction-related artifacts and chipped lithics occur in moderate numbers, while other artifact categories are scarce. As in all other units, the frequencies of all artifact categories decrease with depth, with the highest numbers occurring in the upper two excavation levels (Table 15). Household items, miscellaneous metal fragments, and snail shell remains occur in all levels suggesting some degree of disturbance throughout the deposits. The heaviest disturbances, however, clearly occur in the upper three levels, while Level 3Colonial and 4 have fewer artifacts and also are less disturbed.
Our excavations in the units immediately paralleling the south wall confirm findings from previous work at Mission San José indicating that CWA efforts to trace the colonial foundation involved the excavation of trenches paralleling the outside and inside walls of the Indian Quarters. The outline of this trench is clearly visible in the excavation units dug immediately next to the south wall of the mission (Units 1-5, and 16). In these units, the trench reached to a depth of between 21-29 inches (Figure 4) heavily disturbing all overlying archaeological deposits. The width of the trench ranges from 12-18 inches resulting in mixed deposits in the northern one-third to one-half of each of the units against the base of the wall.

Based on the heavy disturbance noted during previous excavations along the south wall, the upper 12 inches of disturbed deposits were removed by the construction contractor's employees prior to the beginning of archaeological excavations. Level 1 (12-18 inches bs) consisted of disturbed and relatively loose gray sandy loam. It contained construction debris, such as sandstone flakes from shaping and sizing the sandstone blocks used in the reconstruction of the CWA wall, mortar fragments, and numerous pebbles. Level 2 was excavated to a depth at which the black clay layer could be discerned in the southern half of the units and the edge/outline of the CWA trench was visible in the northern portion. It ranged in thickness from $2-4$ inches (18-20 inches bs or 18-22 inches bs). The loose sandy loam matrix exhibited some mottling and contained a range of colonial and post-colonial artifacts indicative of continued disturbance. Level 3CWA consisted of a 2-7 inch thick zone extending from 1218 inches from the wall base. It contained the remaining mixed gray sandy loam matrix found in the bottom of the CWA trench. Level 3Colonial was always ex- 
Table 14. Artifacts from south wall units, by unit

\begin{tabular}{|r|c|c|c|c|c|c|c|c|c|r|r|}
\hline Unit & Ceramic & Household & Personal & $\begin{array}{c}\text { Barn/Workshop/ } \\
\text { Garage }\end{array}$ & Arms & Construction & Lithics & Bone & Shell & $\begin{array}{c}\text { Misc. } \\
\text { Metal }\end{array}$ & Totals \\
\hline 1 & 79 & 58 & 2 & 1 & 0 & 5 & 10 & 535 & 18 & 16 & 724 \\
\hline 2 & 73 & 70 & 0 & 0 & 0 & 27 & 9 & 547 & 12 & 92 & 830 \\
\hline 3 & 31 & 22 & 1 & 0 & 0 & 21 & 1 & 206 & 1 & 35 & 318 \\
\hline 4 & 65 & 124 & 0 & 3 & 3 & 23 & 4 & 81 & 3 & 287 & 593 \\
\hline 5 & 65 & 85 & 1 & 2 & 0 & 34 & 5 & 554 & 3 & 272 & 1021 \\
\hline 16 & 34 & 37 & 0 & 1 & 0 & 12 & 5 & 248 & 1 & 10 & 348 \\
\hline 17 & 80 & 11 & 1 & 0 & 0 & 2 & 4 & 777 & 7 & 3 & 885 \\
\hline 18 & 138 & 43 & 0 & 0 & 0 & 7 & 6 & 980 & 1 & 9 & 1184 \\
\hline 19 & 49 & 30 & 0 & 0 & 1 & 22 & 4 & 237 & 0 & 3 & 346 \\
\hline 20 & 77 & 84 & 1 & 2 & 1 & 47 & 4 & 443 & 2 & 117 & 778 \\
\hline Totals & 691 & 564 & 6 & 9 & 5 & 200 & 52 & 4608 & 48 & 844 & 7027 \\
\hline
\end{tabular}

Table 15. Artifacts from south wall units, by level

\begin{tabular}{|r|c|c|c|c|c|c|c|c|c|c|r|}
\hline Level & Ceramic & Household & Personal & $\begin{array}{c}\text { Barn/Workshop/ } \\
\text { Garage }\end{array}$ & Arms & Construction & Lithics & Bone & Shell & $\begin{array}{c}\text { Misc. } \\
\text { Metal }\end{array}$ & Totals \\
\hline 1 & 252 & 454 & 5 & 9 & 3 & 148 & 22 & 1464 & 31 & 764 & 3152 \\
\hline 2 & 273 & 84 & 1 & 0 & 2 & 45 & 18 & 1981 & 6 & 62 & 2472 \\
\hline $3+3$ cwa & 34 & 17 & 0 & 0 & 0 & 5 & 10 & 226 & 3 & 11 & 306 \\
\hline 3 colonial & 108 & 7 & 0 & 0 & 0 & 0 & 1 & 759 & 6 & 6 & 887 \\
\hline 4 & 24 & 2 & 0 & 0 & 0 & 2 & 1 & 178 & 2 & 1 & 210 \\
\hline Total & 691 & 564 & 6 & 9 & 5 & 200 & 52 & 4608 & 48 & 844 & 7027 \\
\hline
\end{tabular}

cavated to a depth of 24 inches bs. It consisted of the dark gray sandy loam found in the southern half of the units adjacent the south wall or across the entire surface of the unit when the CWA trench did not extend to a depth of 24 inches bs. This level contained fewer post-colonial materials and bone frequencies tended to be higher immediately at the contact between the dark gray sandy loam and the Houston Black Clay substrate. Level 4 (24-30 inches bs) consisted of mottled black clay near the top 3-4 inches and solid black clay below. Artifact recovery, consisting primarily of bone, was low and occurred in the upper three inches of the level.

In addition to the CWA trench, a second feature was also encountered in Unit 16 along the outside of the south wall adjacent the southwest corner of the gate. This feature consisted of a concrete footing for a rectangular 4"-x-4" post (Figure 10). The 4"-x-4" post mold was still visible in the center of the block, al- though remains of the wooden post were not present. The footing measured approximately 28 inches in outside diameter at the top and was found at a depth of 29 inches bs. To expose the southwest corner of the gate the construction contractor and CAR employees excavated the area immediately between Unit 16 and Unit 6, excavated by CAR in 1993 (see Figure 3, and Hard et al. 1995: Figure 12). Since only about a 12inch wide area remained intact between the edge of the 1993 unit and the base of the mission wall and the removal of the upper 12 inches indicated heavy construction-related disturbance, the area was not excavated using archaeological methods. The excavations revealed that a large pit was initially dug to house the concrete footing of the post and that this pit was partially filled with concrete and sandstone rubble to reduce its size before the actual post was placed in the pit. The nature of the post and its location suggest that it may have supported a gate placed in the outside of the entryway rather than on the inside as is the case 


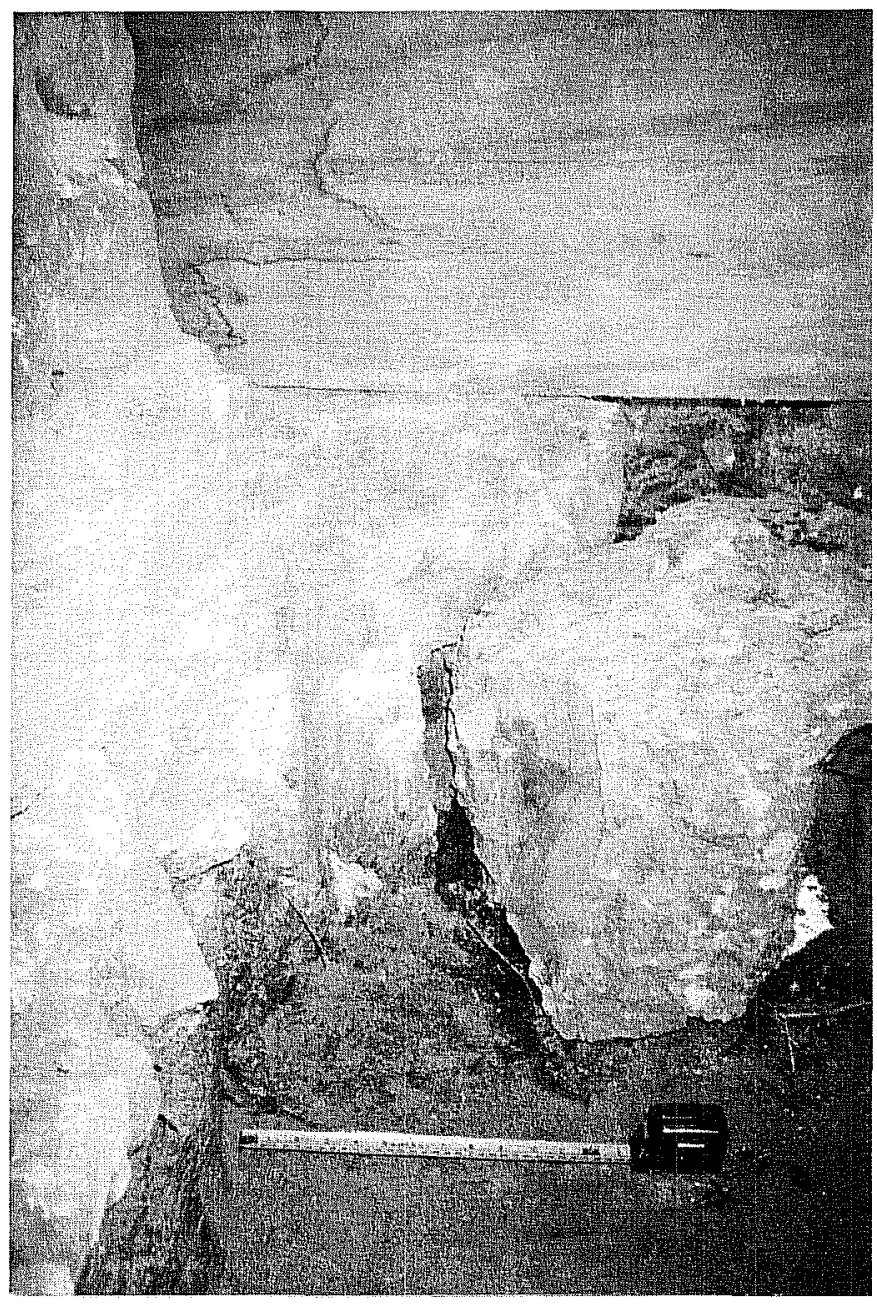

Figure 10. Concrete footing for former gate post at southwest corner of southeast gate. with the currently functioning gate. It remains unclear, however, as to whether this outside gate would have represented a second gate or a modification in the location of the gate. It is further unclear whether this modification of plans occurred during the CWA construction or sometime thereafter.

The breakdown of ceramic types by units indicates that while the partial units (Units 3, 19, and 20) tend to have small collections, the other units are relatively rich in ceramics (Table 16). Unglazed wares and whitewares dominate the collection. While only 56 percent $(n=141$ of 252) of the ceramics from Level 1 are unglazed specimens, 88 percent $(n=30$ of 34$)$ are unglazed from Level 3 (Table 17). Only unglazed wares are present in Levels 3 Colonial and 4 . This pattern suggests that these levels are to a large extent undisturbed, although a small number of postcolonial artifacts are present in both (see Table 15).

The excavation of the units (Nrs. 1-5, 16) located immediately adjacent the south wall indicates that between one-third and one-half of the area of each $3^{\prime}-x-3$ ' unit is disturbed by CWA attempts to locate and trace the original colonial foundation of the Indian Quarters. Although the utilization of a mix of artificial and natural excavation levels does aid in reducing the mixture of colonial and post-colonial materials, no undisturbed deposits remain in a band ranging from 12 to 18 inches from the base of the CWA wall. In Units 17-20, three feet removed from the base of the mission wall, the stratigraphy confirmed

Table 16. Ceramic types by unit recovered from south wall units

\begin{tabular}{|r|c|c|c|c|c|c|r|r|}
\hline Unit & Unglazed & $\begin{array}{c}\text { Lead- } \\
\text { Glazed }\end{array}$ & $\begin{array}{c}\text { Tin- } \\
\text { Glazed }\end{array}$ & Whitewares & Yellowware & $\begin{array}{c}\text { European } \\
\text { Porcelain }\end{array}$ & Stonewares & Totals \\
\hline 1 & 74 & 2 & & 1 & & & 2 & 79 \\
\hline 2 & 55 & 2 & 2 & 9 & 1 & & 4 & 73 \\
\hline 3 & 25 & & 1 & 3 & & & 2 & 31 \\
\hline 4 & 16 & 8 & 2 & 11 & 22 & 4 & 2 & 65 \\
\hline 5 & 42 & 4 & 1 & 8 & 8 & & 2 & 65 \\
\hline 16 & 32 & 1 & & 1 & & & & 34 \\
\hline 17 & 78 & 1 & & 1 & & & & 80 \\
\hline 18 & 129 & 4 & & 3 & & & 2 & 138 \\
\hline 19 & 42 & 3 & 1 & 3 & & & & 49 \\
\hline 20 & 55 & 4 & 2 & 8 & 5 & 1 & 2 & 77 \\
\hline Total & 548 & 29 & 9 & 48 & 36 & 5 & 16 & 691 \\
\hline
\end{tabular}


Table 17. Ceramic types by level recovered from south wall levels

\begin{tabular}{|r|c|c|c|c|c|c|r|r|}
\hline \multicolumn{1}{|c|}{ Level } & Unglazed & $\begin{array}{c}\text { Lead- } \\
\text { Glazed }\end{array}$ & $\begin{array}{c}\text { Tin- } \\
\text { Glazed }\end{array}$ & Whitewares & Yellowware & $\begin{array}{c}\text { European } \\
\text { Porcelain }\end{array}$ & Stonewares & Totals \\
\hline 1 & 141 & 19 & 7 & 36 & 32 & 5 & 12 & 252 \\
\hline 2 & 245 & 9 & 2 & 11 & 3 & & 3 & 273 \\
\hline 3+3CWA & 30 & 1 & & 1 & 1 & & 1 & 34 \\
\hline 3Colonial & 108 & & & & & & & 108 \\
\hline 4 & 24 & & & & & & & 24 \\
\hline Total & 548 & 29 & 9 & 48 & 36 & 5 & 16 & 691 \\
\hline
\end{tabular}

that deposits lying 12-18 inches bs (Level 1) represent a transition zone between heavily disturbed overlying materials and less disturbed underlying colonial materials. Deposits found 18-24 inches bs (Level 2) are less disturbed and contain primarily colonial materials. Only the upper 1-3 inches of deposits in Level 3 (24-30 inches bs) contain material remains. These remains consist almost exclusively of bone and unglazed pottery and represent items that may have worked their way down from the contact zone between the gray sandy loam and the Houston Black Clay found below 19 inches in depth.

\section{Units along the West Wall of the Gate}

Units 14 and 15 were positioned in the only previously unexcavated area along the west wall of the southeast gate. In 1993 CAR excavated two 4'-x-4' units along the west wall of the gate leaving only a approximately six-foot-wide area undisturbed (see Figure 3; Hard et al. 1995: Figure 12). The removal of the 18-inch-thick concrete sidewalk and underlying rubble fill exposed a rubble-free surface at a depth of between 19-21 inches bs. In the eastern third of Unit 15 this newly exposed surface retained a thin layer $(1-3 \mathrm{~cm})$ of orange-yellow ashy material identical to that found on the living surface inside of Room 54 at an equivalent depth. This material represents the remnants of the colonial living surface present in the Indian Quarters. The fact that the material was powdery and loose rather than packed indicates that much of the upper portion of the living surface had been disturbed by either the construction of the old mission road that ran through this gate or by the construction of the concrete sidewalk. The disturbance was clearly evident in the western half of the unit where the living surface had been entirely removed and a large chunk of concrete was sitting directly on black clay. The colonial living surface was not present in Unit 14, which yielded clear glass and wire fragments together with Goliad ceramics and bone sitting on black clay at a depth of 21-28 inches bs. However, the remnants of the colonial living surface were noted in the area immediately east of the two units and extending under the concrete sidewalk. This area was not excavated but the observation indicates that Indian Quarters rooms extended across the location of the present southeast gate.

Table 18. Artifacts recovered from west wall units of southeast gate, by unit

\begin{tabular}{|r|c|c|c|c|c|r|r|}
\hline Unit & Ceramic & Household & Personal & Construction & Lithics & Bone & Totals \\
\hline 14 & 3 & & 1 & 6 & & & 10 \\
\hline 15 & 7 & 3 & 0 & 4 & 2 & 69 & 85 \\
\hline Total & 10 & 3 & 1 & 10 & 2 & 69 & 95 \\
\hline
\end{tabular}

Table 19. Artifacts recovered from west wall units of southeast gate, by level

\begin{tabular}{|r|c|c|c|c|c|r|r|}
\hline Level & Ceramic & Household & Personal & Construction & Lithics & Bone & Totals \\
\hline 1 & 3 & & 1 & 6 & 1 & 14 & 25 \\
\hline 2 & 1 & 3 & & 4 & & 44 & 52 \\
\hline 3colonial & 6 & & & & 1 & 11 & 18 \\
\hline Total & 10 & 3 & 1 & 10 & 2 & 69 & 95 \\
\hline
\end{tabular}


Less than 100 artifacts were recovered from the two units, the majority consisting of faunal remains (Table 18). Ceramic fragments and construction debris occur in moderate numbers, while other artifact categories are infrequent. Level 2 (Unit 15) contains the largest number of artifacts, primarily bone, since it consisted of the contact zone between the cultural zone and the sterile black clay substrata (Table 19). The ten ceramic fragments encountered in the two units (three in Unit 14, seven in Unit 15) are unglazed specimens. It appears that in Unit 14, much of the contact zone had been removed prior to the construction of the sidewalk and during the initial construction of the original roadway that ran through the southeast gate of the mission.

\section{The Artifacts}

\section{Anne A. Fox and Steve A. Tomka}

Artifacts totaling 14,089 were recovered from the shovel-testing and underpinning excavations conducted at Mission San José (Table 20). Animal bone fragments, miscellaneous metal pieces, household items, and ceramics constitute the bulk of the materials. Construction materials also are common, whereas chipped lithics occur in relatively small numbers. Other artifact categories are scarce.

In general, the collection contains objects that are commonly found on all Spanish colonial and early nineteenth century sites in the San Antonio area. The eighteenth-century artifacts derive from and reflect the occupation of the site by the mission inhabitants. The nineteenth-century items were probably deposited by the later citizens of the community. The following descriptions are limited to artifacts that can in some way be used for the interpretation of the site.

\section{Ceramics}

Ceramics are the most useful for dating the deposits on a Spanish colonial site. They changed regularly in style and technique of manufacture throughout the eighteenth and nineteenth centuries. Analysis of the age and degree of integrity of the deposits investigated in this project relies primarily on the ceramic fragments recovered. This is then confirmed by the approximate dating of other types of artifacts found with them. The chronology of South Texas historic ceramics is shown in Figure 11.

Ceramics totaling 1,338 were recovered from the 39 shovel tests and the units excavated adjacent the southwest corner of the southeast gate of Mission San José. The majority ( $n=1,036,77$ percent) came from the excavation units, while 23 percent $(n=302)$ are from the shovel tests (Table 20). The collection has been divided into eight broad ceramic groupings, with unglazed, lead-glazed, and tin-glazed, and whiteware specimens being subdivided into types.

\section{Unglazed Wares}

Unglazed ceramics totaling 890 were recovered (Table 21). Of these, 760 (86 percent) are from the excavation units, while the remainder $(n=130,14$ percent $)$ are from the shovel tests. In total, unglazed ceramics make up by far the majority (66 percent) of the ceramics recovered during this work. Four types of unglazed ceramic wares were identified in the collection. In addition, several sherds $(n=12)$ are too small to be identified with confidence; they are classified as unidentified other unglazed wares (Table 22).

The most common of the unglazed ceramic type is Goliad ware. Specimens numbering 859 were identified. Goliad ware has a distinctive red brown to dark

Table 20. All artifacts from shovel testing and underpinning excavation units, Mission San José

\begin{tabular}{|l|c|c|c|c|c|c|c|c|c|c|c|c|}
\hline & Ceramic & $\begin{array}{c}\text { House- } \\
\text { hold }\end{array}$ & $\begin{array}{c}\text { Per- } \\
\text { sonal }\end{array}$ & $\begin{array}{c}\text { Barn/Work- } \\
\text { shop/Garage }\end{array}$ & Arms & $\begin{array}{c}\text { Construc- } \\
\text { tion }\end{array}$ & Lithics & Bone & Shell & $\begin{array}{c}\text { Misc. } \\
\text { Metal }\end{array}$ & $\begin{array}{c}\text { Plas- } \\
\text { tics }\end{array}$ & Totals \\
\hline Excavation Units & 1036 & 1044 & 11 & 10 & 7 & 418 & 99 & 7125 & 76 & 1435 & 0 & 11261 \\
\hline Shovel Test & 302 & 455 & 6 & 11 & 0 & 187 & 18 & 1606 & 10 & 216 & 17 & 2828 \\
\hline Totals & 1338 & 1499 & 17 & 21 & 7 & 605 & 117 & 8731 & 86 & 1651 & 17 & 14089 \\
\hline
\end{tabular}




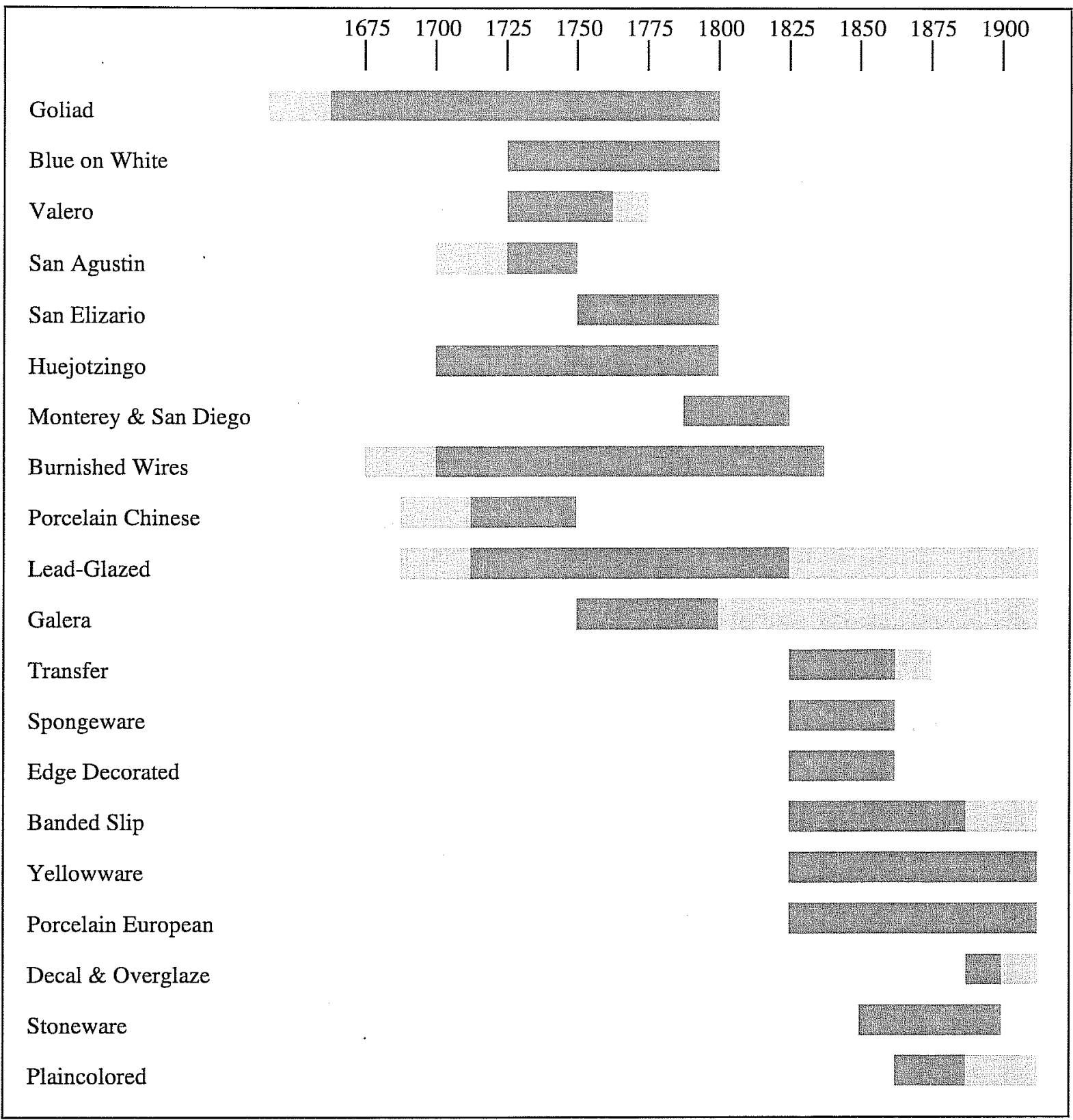

Figure 11. Chronology of South Texas historic ceramics. Intensity of shading is indicative of popularity.

brown color on the exterior and usually has a black core, due to low firing temperatures. It contains bone tempering and appears identical to the Leon Plain ceramics of the Late Prehistoric period in South Texas. Spanish colonial artifact inventories in the San Antonio and Guadalupe River valleys are dominated by this ceramic type, strongly suggesting that it originated among the Indians of the South Texas area (Fox et al. 1976:67).

The second most common unglazed ceramic is the Valero type, consisting of only 17 specimens. This is another unglazed ware type that is often found on San Antonio mission sites (Fox et al. 1976:67). The sherds are from large Mexican-made jars and ollas which were probably used as water jars. They are wheelmade and sometimes bear red painted decorations.

Two types of unglazed burnished wares are common on mission sites in San Antonio. Both appear to be direct descendants of pre-Columbian traditions in Mexico. A tan-bodied ware with burnished red slip or burnished red, black, and yellow slip-painted designs has been identified as coming from Tonalá, Jalisco 
Table 21. All ceramics recovered from underpinning testing and excavations at Mission San José

\begin{tabular}{|c|c|c|c|c|c|c|c|r|r|}
\hline Units & Unglazed & $\begin{array}{c}\text { Lead- } \\
\text { Glazed }\end{array}$ & $\begin{array}{c}\text { Tin- } \\
\text { Glazed }\end{array}$ & $\begin{array}{c}\text { White- } \\
\text { ware }\end{array}$ & $\begin{array}{c}\text { Yellow- } \\
\text { ware }\end{array}$ & $\begin{array}{c}\text { Chinese } \\
\text { Porcelain }\end{array}$ & $\begin{array}{c}\text { European } \\
\text { Porcelain }\end{array}$ & Stoneware & Totals \\
\hline Shovel Testing & 130 & 33 & 21 & 98 & 1 & 0 & 15 & 4 & 302 \\
\hline Excavation & 760 & 54 & 15 & 109 & 39 & 1 & 8 & 50 & 1036 \\
\hline Totals & 890 & 87 & 36 & 207 & 40 & 1 & 23 & 54 & 1338 \\
\hline
\end{tabular}

Table 22. Unglazed ceramics recovered from Mission San José

\begin{tabular}{|l|c|c|c|c|c|r|}
\hline \multicolumn{1}{|c|}{ Units } & Goliad & Tonala & Valero & $\begin{array}{c}\text { Red } \\
\text { Burnished }\end{array}$ & $\begin{array}{c}\text { Other } \\
\text { Unglazed }\end{array}$ & Totals \\
\hline ST Units & 125 & & 3 & 1 & 1 & 130 \\
\hline Excavation Units & 734 & 1 & 14 & & 11 & 760 \\
\hline Totals & 859 & 1 & 17 & 1 & 12 & 890 \\
\hline
\end{tabular}

(Charlton and Katz 1979). One sherd of this type came from Level 1 of Unit 2. A burnished ware with red body commonly occurs in Spanish colonial sites. A single sherd of this type was recovered during shovel testing (ST 8, Level 1).

\section{Lead-Glazed Utility Wares}

The 87 lead-glazed sherds include five types commonly found on mission sites (Table 23). None of the sherds is large enough to determine vessel shapes or sizes. The vessels from which the sherds derive were probably made in Mexico and arrived in Texas in the annual shipment of supplies.

Bowls and jars of sandy paste earthenware make up the largest group of lead-glazed wares. The glaze is clear or very pale green, exposing and intensifying the pink-to-orange color of the paste beneath (Fox 1974:56). This collection contains 49 sherds ( 57 percent) of this type. The majority of the fragments appear to represent deep bowls and jars.
After the mid-eighteenth century, wares characterized by a thin, orange body covered on the inside and over the rim onto the outside with a clear, thin lead glaze began to be made. Chocolateros and bean pots of this ware may be decorated with brown, yellow, and green floral designs on their upper body. The term Galera ware is accepted for this ware across the southwest to California (Barnes 1980:102; Gerald 1968:54). These excavations recovered 22 ( 26 percent) Galera sherds.

Sherds with a red body covered with a thin lead glaze that intensifies the mahogany color of the vessel occur occasionally on Texas mission sites (Fox 1974:59). Schuetz (1969:51) called this Guadalajara ware. Fox (1974:59) hesitates to ascribe to it a particular Mexican location, referring to it instead as Red-Brown ware. A total of four ( 5 percent) Red-Brown ware specimens were recovered at San José.

A lead-glazed pottery type consisting of a creamy beige body decorated with brown linear designs and covered with a clear glaze (Fox 1974:58) is found occasionally on San Antonio River sites. This may be a late-eighteenth-century type which has carried over into the present. Bowls that resemble this ware are

Table 23. Lead glazed ceramics recovered from Mission San José

\begin{tabular}{|l|c|c|c|c|c|c|r|}
\hline \multicolumn{1}{|c|}{ Units } & $\begin{array}{c}\text { Sandy } \\
\text { Paste }\end{array}$ & Galera & $\begin{array}{c}\text { Red on } \\
\text { Brown }\end{array}$ & $\begin{array}{c}\text { Yellow on } \\
\text { Brown }\end{array}$ & $\begin{array}{c}\text { Olive } \\
\text { Jar }\end{array}$ & Other & Totals \\
\hline ST Units & 21 & 8 & 1 & & 1 & 2 & 33 \\
\hline Excavation Units & 28 & 14 & 3 & 5 & & 4 & 54 \\
\hline Totals & 49 & 22 & 4 & 5 & 1 & 6 & 87 \\
\hline
\end{tabular}


still being made in Mexico today. Five (6 percent) yellow with brown sherds were found in this collection.

One sherd in this collection represents an olive jar, used originally for shipping liquids such as wine and olive oil to the New World from Spain (Goggin 1968:253). Such sherds usually have a green glaze on one face, and a white slip on the other.

Finally, six sherds ( 7 percent) either could not be identified or represent vessels only occasionally found on mission sites. Two sherds with black luster glaze on bone-tempered pottery came from ST 24, Level 1. Schuetz (1969:52) states that black luster glaze when on a bone tempered body can be ascribed to Santa Fe, Michoacan.

\section{Tin-Glazed Wares}

Tin-glazed earthenwares are covered with a lead glaze to which tin has been added to create a white or creamcolored enamel decoration. The styles and colors of their decoration changed periodically, making them useful for comparative dating of sites and of deposits within them. A total of 36 tin-glazed specimens were identified in the sample (Table 24).

The term blue on white has been used here to indicate all sherds that show evidence of blue decoration, but which cannot be further classified. Fifteen such sherds were recovered during these excavations.

After about 1810 , a new color combination of rust, green, and brown/black on a greenish cream background appeared (Lister and Lister 1974:Figure 12). Called Guanajuato for the area where it was made, this ware appears on all the San Antonio mission sites and on early nineteenth-century sites in Laredo (Folan et al. 1986; Clark and Juarez 1986). Two sherds of this type were found during this project.

One unusually thin sherd with delicate brown and blue decoration on a white background represents a type occasionally found in late eighteenth century deposits. Schuetz (1969:57) originally reported this type at Mission San Juan, and more recently it has been found at other colonial sites. The single specimen from Mission San José came from Level 1 of Shovel Test 11.

Two rim sherds bearing a green band over the rim appear to fall into the Huejotzingo type. These are unusual in that the type is most commonly bluerimmed, but other colors are very occasionally found.

Three sherds bear polychrome decoration but are too small to readily identify the pattern. For the most part, polychrome-decorated majolicas found at the San Antonio missions can be dated to the last quarter of the eighteenth century.

Undecorated sherds can represent totally undecorated vessels, which were made throughout the eighteenth century (Lister and Lister 1974:30). They also can be merely undecorated sections of vessels bearing painted designs. Thirteen undecorated sherds were found.

\section{Whitewares}

The presence of white-bodied wares is generally an indicator of nineteenth-century occupation on San Antonio sites. British-made white-bodied wares began to appear in this area in the early $1830 \mathrm{~s}$. At first most of these wares were decorated with various bright colors in a number of different techniques. After the Civil War, plain whitewares became fashionable and took over the market. A total of 207 whitewares have been recovered during these excavations (Table 25). They were almost equally common in shovel tests

Table 24. Tin-glazed ceramics recovered from Mission San José

\begin{tabular}{|r|c|c|c|c|c|c|c|}
\hline \multicolumn{1}{|c|}{ Units } & $\begin{array}{c}\text { Blue on } \\
\text { White }\end{array}$ & Guanajuato & $\begin{array}{c}\text { Blue on } \\
\text { Brown\&White }\end{array}$ & Huejotzingo & $\begin{array}{c}\text { Polychrome } \\
\text { Jar }\end{array}$ & Undecorated & Totals \\
\hline ST Units & 8 & 1 & 1 & 2 & 3 & 6 & 21 \\
\hline Excavation Units & 7 & 1 & & & & 7 & 15 \\
\hline Totals & 15 & 2 & 1 & 2 & 3 & 13 & 36 \\
\hline
\end{tabular}


Table 25. Whiteware ceramics recovered from Mission San José

\begin{tabular}{|c|c|c|c|c|c|c|c|c|r|}
\hline \multicolumn{1}{|c|}{ Units } & $\begin{array}{c}\text { Hand- } \\
\text { Painted }\end{array}$ & Sponged & Banded & Transfer & Decal & $\begin{array}{c}\text { Over- } \\
\text { Glazed }\end{array}$ & $\begin{array}{c}\text { Other } \\
\text { Decorated }\end{array}$ & $\begin{array}{c}\text { Undec- } \\
\text { orated }\end{array}$ & Totals \\
\hline ST Units & 6 & 6 & 17 & 5 & & & 1 & 63 & 98 \\
\hline Excavation Units & 11 & 1 & 4 & 3 & 4 & 1 & & 85 & 109 \\
\hline Totals & 17 & 7 & 21 & 8 & 4 & 1 & 1 & 148 & 207 \\
\hline
\end{tabular}

$(n=98)$ and excavation units $(n=109)$. The relatively high proportion of whitewares in the shovel tests is probably due to the shallow depth of these excavations and the higher likelihood that they sampled primarily nineteenth-century materials. The 207 whitewares recovered can be grouped into seven decorative styles, including hand painted ( $\mathrm{n}=17)$, sponged $(n=7)$, banded slip ware $(n=21)$, transfer wares $(n=8)$, decal-decorated $(n=4)$, over-glaze painted $(n=1)$, undecorated sherds $(\mathrm{n}=148)$, and a single specimen that could not be categorized.

A portion of the undecorated sherds of whiteware probably represents fragments of plain white Ironstone plates. The remainder may come from earlier decorated vessels. Of the 148 undecorated sherds, 85 (57 percent) are from excavation units while the remaining 63 (43 percent) are from shovel tests.

\section{Yellowware}

In the late nineteenth and early twentieth century, heavy yellow kitchen ware was produced in the United States. It was used for utility vessels such as mixing bowls and pie plates available to housewives through mail order catalogs and hardware stores (Roycraft and Roycraft 1975:Plate 16). A total of 40 yellowware sherds were recovered, all from excavation units (Table 26).

\section{Chinese Porcelain}

Delicate cups and bowls of porcelain arrived at Acapulco aboard the Manila galleons in the early eighteenth century. Mexican buyers transported them to Mexico City where they were purchased by Franciscan conductors of supplies and hauled to the frontier missions. One sherd decorated over the glaze with red painted design was recovered during these excavations (Table 26).

\section{European and American Porcelain}

There are 22 sherds of European or American porcelain in this collection (Table 26). The majority come from shovel tests. Thin, vitrified, translucent, some of these sherds may have originated in Europe, where most porcelain was made until late in the nineteenth century. Families often had just a few pieces (e.g., tea cups and saucers, dessert plates) which they saved for special occasions.

\section{Stoneware}

Fifty-five stoneware sherds were recovered. Stoneware is a dense, hard ceramic with a white, tan, or gray paste. Vessels made of this ware were used for food preparation and storage. Bexar County potters made these wares for local consumption from the last quarter of the nineteenth century until the 1920s (Fox 1998).

Table 26. Other ceramic wares recovered from Mission San José

\begin{tabular}{|c|c|c|c|c|c|r|}
\hline \multicolumn{1}{|c|}{ Units } & Yellowwares & $\begin{array}{c}\text { Chinese } \\
\text { Porcelain }\end{array}$ & $\begin{array}{c}\text { European } \\
\text { Porcelain }\end{array}$ & Stonewares & Other & \multicolumn{1}{c|}{ Totals } \\
\hline ST Units & 1 & & 14 & 4 & 1 & 20 \\
\hline Excavation Units & 39 & 1 & 8 & 51 & & 99 \\
\hline Totals & 40 & 1 & 22 & 55 & 1 & 119 \\
\hline
\end{tabular}




\section{Other Type}

Classified as "other," one sherd represents an early twentieth-century pottery type commonly found on sites of that period. It is glazed on both sides in a pastel shade of blue, green, yellow, or pink. In this case, the sherd is pale green. It was recovered in Level 1 of Shovel Test 9.

\section{Glass, Metal, and Miscellaneous Artifacts}

\section{Household Items}

A total of 1,499 household items have been recovered from excavations at Mission San José (Table 20). They are grouped into two general types: glass containers $(n=1,494)$ and kitchenware fragments $(n=5)$. As expected, a majority of the glass container fragments $(\mathrm{n}=1,044,70$ percent) come from excavations, as do four ( 80 percent) of the kitchenware fragments.

\section{Glass Containers}

A total of 1,494 fragments of glass containers of various colors was identified. Only seven ( $>1$ percent) are fragments of olive green bottle glass from the colonial period. One specimen was found in Level 1 of Unit 10 (Figure 12a), and six come from Shovel Test 21 , located along the west wall of the mission, about 75 feet north of the southwest gate. The remaining specimens, the bulk of the sample, represents nineteenth- and twentieth-century container fragments.

\section{Kitchen Items}

Only five kitchen items were recovered. Two of the specimens are fragments of a cast iron frying pan (Figure $12 b$ ). They were recovered in Level 1 of Unit 20 . A bottle opener (Figure 12c) and the end from a holein-top can, a type in use from the middle nineteenth century until about 1900 , came from the same provenience. A large size can opening key (Figure 12d) came from Level 1 of Unit 9. Keys of this size are used for canned meats (Vaughn 1997:213).

\section{Personal Items}

Personal items include such artifact categories as clothing (e.g., buttons, buckles, fasteners), amusements (games, toys, marbles), personal objects (pipes, jackknives, combs, writing materials), and jewelry (beads, pendants, earrings). A total of 17 personal items were found (Table 20). Amusements $(n=5)$, personal objects $(n=5)$, and clothing items $(n=5)$ make up the bulk of the specimens. Only two jewelry pieces were found. Of the 17 personal items, 11 (65 percent) are from excavation, and the remainder ( $n=6,35$ percent) come from shovel tests. Of these artifacts, amusement items have the most bearing on the temporal affiliation of the deposits.

Four of the five amusement objects are fragments of small molded bisque dolls, sometimes called candy store dolls (Meissner 1997:61). They were recovered from Level 1 of Unit 1, Level 2 of Unit 17, Level 1 of ST 3, and Level 1 of ST 8. Such dolls were inexpensive and popular in the years before World War I (Angione 1973:220). The fifth amusement object is a common earthenware marble made in the last half of the nineteenth century (Zapata 1997:108). It came from Level 1 of Unit 7. The two jewelry pieces are both glass beads. One is a clear glass faceted bead that dates sometime between the late eighteenth and early nineteenth century. The second is a blue-black glass bead of indeterminate temporal affiliation. The clothing items represent various fasteners and the personal objects represent fragments of writing instruments $(n=3)$, a small key, and a coin. The coin, a $1909 \mathrm{Lib}-$ erty Quarter (Yeoman 1967:121) was recovered from Level 1 of ST 36, located along the east wall of the mission.

\section{Arms}

The seven arms-related finds in the collection are shotgun shells. They were apparently made by a number of different makers, but the marks are too corroded to be legible. All seven were recovered in excavation units (Table 20). 


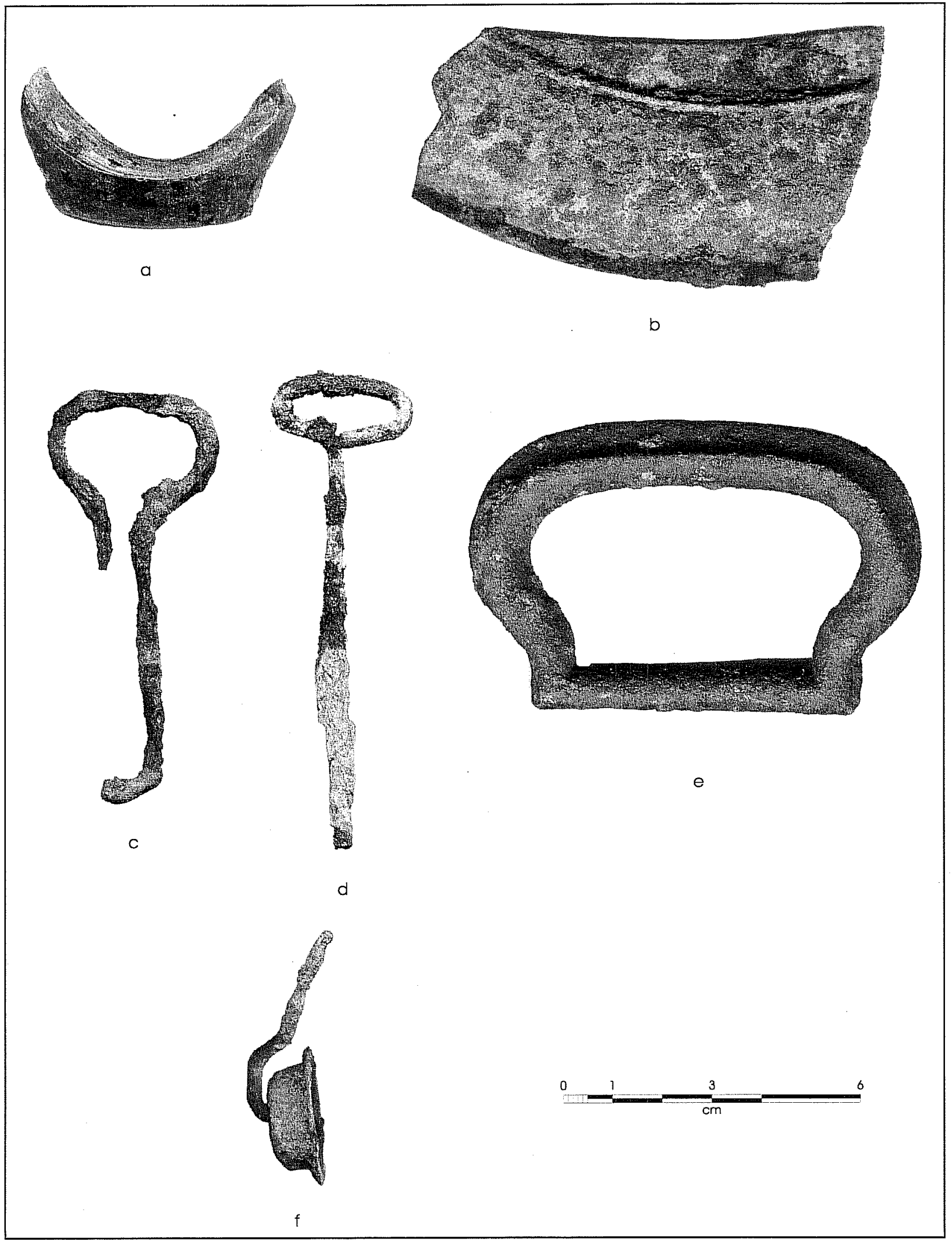

Figure 12. Historic artifacts from Mission San José: a. olive green Colonial Period bottle glass; $b$. fragment of cast iron pan; c. bottle opener; d. can-opening key; e. iron handle or buckle; f. lard can bale handle. 


\section{Construction Materials}

A total of 605 artifacts are included in this category (Table 20). They are divided into three broad categories: nails (cut and wire), other hardware (e.g., screws, bolts, hinges, wire, etc.), and building materials (window glass, bricks, tiles, concrete, mortar, utilities). The artifacts are divided nearly equally between the three categories. The largest group consists of building materials $(n=215 ; n=156$ from excavation, $n=59$ from shovel tests). Other hardware items are also numerous ( $n=199 ; n=154$ from excavation, $n=45$ from shovel tests). Nails are not far behind in numbers with a total of 191 specimens $(n=109$ from excavation, $n=82$ from shovel testing).

\section{Nails}

Of the nails recovered during this project, by far the majority $(n=152)$ are wire nails. Eighty-seven ( 57 percent) wire nails were recovered in excavations, the remaining 65 (43 percent) were found in test excavations. In San Antonio, this type of nail dates from the very end of the nineteenth century until the present. A smaller number of square nails $(n=39)$ probably represent the mid-to-late nineteenth-century construction of small houses along the original line of walls at the mission. Twenty-two (56 percent) of the cut nails are from excavation units, the other 17 (44 percent) are from various shovel tests.

\section{Other Hardware}

A total of 199 artifacts are classified as other hardware items. The large majority ( $\mathrm{n}=154,77$ percent) are from excavation units. The remaining 45 (23 percent) specimens are from test excavations. No temporally diagnostic artifacts are present within this group.

\section{Building Materials}

The number of artifacts that can be classified as building materials totals 215 items. Of these, 156 (73 percent) are from excavation units while the other 59
(27 percent) are from test excavations. Among the 215 items are numerous fragments of colonial brick or tile. When whole, these bricks average about one inch in thickness and are rectangular in shape. This kind of brick is readily separable from modern brick by its relative shape and its light red tan color. In addition to the brick fragments, a total of 96 pieces of window glass was also recovered. All of the specimens appear to date to the late nineteenth and early twentieth century.

\section{Miscellaneous Metal}

A total of 1,651 specimens were obtained in these excavations (Table 20). They consist of unidentified metal fragments ( $n=1,590,96$ percent), and identified metal objects $(n=61,4$ percent). The large majority of both categories derive from 3 '-x-3' excavation units.

\section{Metal Fragments}

Unidentifiable thin rusted metal fragments represent disintegrated tin cans and other thin iron objects. For the most part they are found in late-nineteenth-century deposits, and in this case may often suggest disturbance within the site.

\section{Metal Objects}

Sixty-one identifiable metal objects were recovered. Among these the greatest number are bottle caps which turned up in various levels. Also frequently found were fragments of metal strapping similar to that used for barrel hoops. Small wooden barrels were used as containers for various commodities from nails to food products during the nineteenth century.

An interesting iron handle or buckle came from Shovel Test 6 (Figure 12e). It is too regular in shape to be hand-forged and probably is somewhat related to a late-nineteenth-century horse harness or simple farm machinery. A small, dome-shaped artifact to which a section of heavy wire is attached (Figure 12f) is an object often found on late-nineteenth or early 
twentieth-century sites and is occasionally misidentified in archaeological reports. This is the attachment for a bale handle of a lard can (Vaughan 1997:Figure 7-1b). The practical housewife found many additional uses for such cans once the original contents had been used up, causing them to linger for many years on a site after lard was no longer sold in these containers.

\section{Lithic Artifacts}

Chipped lithic artifacts numbering 117 were recovered during shovel testing and excavations at Mission San José. The large majority ( $\mathrm{n}=99,85$ percent) came from excavations while only 18 items were recovered during shovel testing. The majority ( 81 percent) of the collection consists of unmodified lithic debitage, mostly from excavation units. The remaining specimens ( $n=22,19$ percent) are categorized into the following functional groups: four arrow points, two gun flints, two scrapers, four knives, and three cores (Table 27). Tool function was determined by low-powered $(20 x-80 x)$ micro-wear analysis. Six unifacially flaked artifacts are classified as indeterminate unifaces, and a bifacially flaked specimen is classified as a miscellaneous biface. All artifacts are of fine-grained chert that was most likely obtained from the nearby San Antonio River.

\section{Arrow Points}

Four artifacts are classified as arrow point blanks. They include one complete specimen, as well as a distal, a proximal, and a longitudinal fragment. The complete specimen is a small, roughly triangular, tertiary flake with minimal bifacial retouch along portions of the lateral edges (Figure 13a). The flake removals extend only 3-5 $\mathrm{mm}$ from the edges and are present only along the proximal $17 \mathrm{~mm}$ of the $27-\mathrm{mm}$-long point. The distal and proximal fragments are fully bifacially flaked. The distal fragment was broken in use. The proximal specimen has a straight base and parallel edges (Figure 13b). The morphology of the break face and a partial removal scar on the base suggest that the specimen was broken during a failed basal thinning attempt. The longitudinal fragment is also a small hinge fractured tertiary flake. The flake blank has been bifacially flaked on one margin and exhibits a perverse longitudinal break created during manufacture. Because neither of the three specimens appears to have been completed, they are all classified as arrow point blanks. Although the intended type cannot be established, it is likely that they represent the very early stages of Guerrero point manufacture. This point type is commonly associated with mission occupations (Turner and Hester 1993:216). The specimens are characterized by triangular to lanceolate outlines and slightly to moderately concave bases.

\section{Gun Flints}

Two gunflints made of local-origin fine-grained chert were identified. Based on differential patina, the blank employed for the larger of the specimens appears to be a recycled blade shaped through unifacial flaking (Figure 13c-d). It has been flaked along its entire perimeter and has a roughly rectangular shape. Only one edge, however, exhibits the step fractured and crushed macro-wear characteristic of gun flints. It is $8 \mathrm{~mm}$ thick, measures $25 \mathrm{~mm}$ in length and $24 \mathrm{~mm}$ in width (Table 27). The second specimen also appears to have been made on a blade or a heavily recycled uniface distal fragment. It has an irregular shape and three edges exhibit the crushed somewhat rounded use wear characteristic of gun flints.

\section{Scrapers}

Two unifacial scrapers have been recovered from the San José excavations (Table 27). Based on the location of their working edges they are both classified as side scrapers. Based on the degree of retouch on their working edges, one of the specimens has two expediently modified working edges (i.e., modified by use not retouch), while the other has a formal concave, spoke shave-type, working edge and a second expediently modified working edge. 
Table 27. Chipped lithic tools recovered from shovel testing and excavations associated with southeast gate underpinning, Mission San José

\begin{tabular}{|c|c|c|c|c|c|c|c|}
\hline \multirow[b]{2}{*}{ UNIT } & \multirow[b]{2}{*}{ LEVEL } & \multirow[b]{2}{*}{ TOOL TYPE } & \multicolumn{3}{|c|}{ Maximum Dimensions (mm) } & \multirow[b]{2}{*}{ Blank } & \multirow[b]{2}{*}{ Notes } \\
\hline & & & Length & Width & Thickness & & \\
\hline & & Arrow Points & & & & & \\
\hline ST5 & 2. & Arrow Point Blank & & & 4 & Indet. & Use broken distal frag. \\
\hline 16 & 2 & Arrow Point Blank & 27 & 18 & 4 & Flake & $\begin{array}{l}\text { Triangular flake w. minimal } \\
\text { flaking }\end{array}$ \\
\hline 18 & 2 & Arrow Point Blank & & 17 & 4 & Indet. & Manufacture broken \\
\hline 17 & 2. & Arrow Point Blank & & & 10 & Flake & Longitudinally broken blank \\
\hline & & Gun Flint & & & & & \\
\hline 18 & 2 & Reworked Unifacial Tool & 25 & 23 & 8 & Tertiary flake & $\begin{array}{l}\text { Roughly rectangular w. one used } \\
\text { edge }\end{array}$ \\
\hline 20 & 1. & Reworked Unifacial Tool & 22 & 21 & 9 & Tertiary flake & $\begin{array}{l}\text { Irregular shape, w. three working } \\
\text { edges }\end{array}$ \\
\hline & & Scrapers & & & & & \\
\hline 18 & 2 & Expedient Side Scraper & 42 & 31 & 7 & Tertiary blade & $\begin{array}{l}\text { Single faceted platform, two } \\
\text { working edges }\end{array}$ \\
\hline 2 & 1 & $\begin{array}{l}\text { Expedient Side Scraper/Spoke } \\
\text { Shave }\end{array}$ & 51 & 44 & 13 & Secondary flake & $\begin{array}{l}\text { Distal frag., with two working } \\
\text { edges }\end{array}$ \\
\hline & & Knives & & & & & \\
\hline ST7 & 1 & Expedient Knife & & 44 & 11 & Secondary blade & $\begin{array}{l}\text { Distal blade frag., with two } \\
\text { working edges }\end{array}$ \\
\hline 1 & 1 & Expedient Knife & 53 & 39 & 9 & Tertiary flake & $\begin{array}{l}\text { Single faceted platform, one } \\
\text { working edge }\end{array}$ \\
\hline 2 & 1 & Expedient Knife & 32 & 15 & 6 & Tertiary blade & $\begin{array}{l}\text { Multi-faceted platform, one } \\
\text { working edge }\end{array}$ \\
\hline 3. & $3 \mathrm{col}$. & Expedient Knife (denticulate) & & 38 & 7 & Secondary flake & $\begin{array}{l}\text { Distal flake frag., one working } \\
\text { edge }\end{array}$ \\
\hline & & Miscellaneous Biface & & & & & \\
\hline ST7 & 1 & Cortex backed & 32 & 48 & 12 & Small pebble & $\begin{array}{l}\text { Bifacially flaked along one edge, } \\
\text { opposite edge cortex backed }\end{array}$ \\
\hline & & Indeterminate Unifaces & & & & & \\
\hline ST11 & 1 & Indeterminate Uniface Edge & & & 4 & Secondary blade & $\begin{array}{l}\text { Prox. blade frag., w. single faceted } \\
\text { platform, one working edge }\end{array}$ \\
\hline 13 & 3 & Indeterminate Uniface Edge & & & & Indeterminate & Inditerminate uniface edge frag. \\
\hline 18 & 2. & Indeterminate Uniface Edge & & & & Indeterminate & Inditerminate uniface edge frag. \\
\hline 18 & 2 & Indeterminate Uniface Edge & & & & Secondary flake & Inditerminate uniface edge frag. \\
\hline 18 & 2 & Indeterminate Uniface Edge & & & & Indet. blade & Inditerminate uniface edge frag. \\
\hline 20 & 1 & Indeterminate Uniface Edge & & & & Indeterminate & Inditerminate uniface edge frag. \\
\hline & & Cores & & & & & \\
\hline 7 & 3 & Split Pebble Core & 47 & 42 & 25 & Chert pebble & $\begin{array}{l}\text { Ten removal scars, multi- } \\
\text { directional }\end{array}$ \\
\hline 8 & 2 & Pebble Core & 45 & 38 & 21 & Chert pebble & $\begin{array}{l}\text { Eleven removal scars, multi- } \\
\text { directional }\end{array}$ \\
\hline 81 & 21 & Flake Core & & 50 & 12 & Secondary flake & $\begin{array}{l}\text { Prox. flake frag., five removal } \\
\text { scars, broken in red }\end{array}$ \\
\hline
\end{tabular}

\section{Knives}

Four items with scalloped acute working edges reminiscent of serrated knife blades (Table 27) are included in this group. Three of the four came from excavation units while the fourth was found in a shovel test. One of the three is a small tertiary blade with a single working edge. A second specimen is a secondary distal flake 


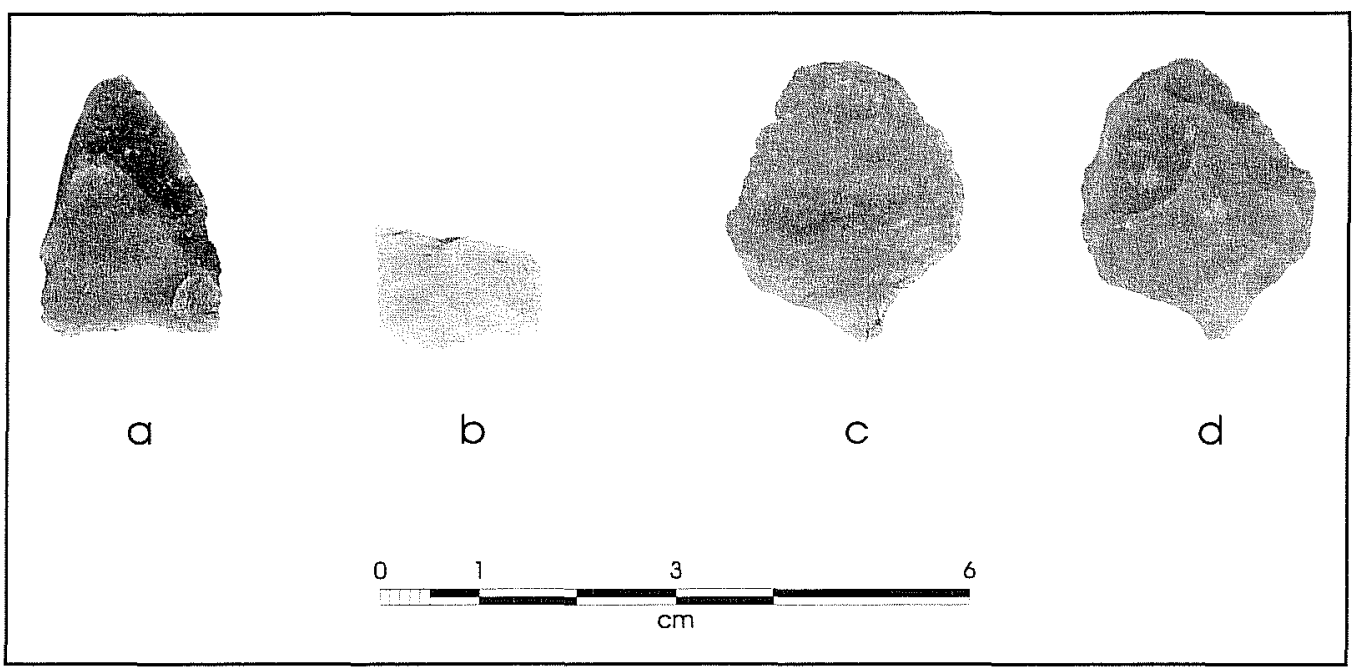

Figure 13. Chipped lithic artifacts from Mission San José: a. complete arrow point blank; b. arrow point blank proximal fragment; c-d. gun flint, (c) obverse face and (d) reverse face made on a recycled blade.

fragment with macroscopic wear on the distal end. An additional specimen is the distal fragment of a secondary blade. It has two working edges. The final specimen is a thick tertiary flake with one working edge. Although the working edge is not retouched, a small number of flakes have been removed on either side of the bulb of percussion off the ventral face of the flake. These removals create an isolated striking platform and give the appearance of a contracting stem to the proximal end of the flake. It is possible that this retouch was purposeful to provide a haft element for a handle. However, no haft-wear can be identified at low magnification. Even though the specimen may have been hafted, the presence of only use wear on its working edge indicates that it was used in a very expedient manner.

\section{Indeterminate Unifaces}

Six unifacially retouched and/or modified flake fragments are included in this category. These specimens represent items that could not be classified into functional tool categories (e.g., end or side scrapers, or knives, etc.) due to their fragmentary nature or lack of use-wear. Five of the specimens have retouched edges, while the sixth exhibits modification derived only from use (Table 27). These specimens were simply too incomplete to allow meaningful measurements of dimensions.

\section{Indeterminate Biface}

A single item is included in this category. The complete specimen is a small cortex-backed pebble with a bifacially flaked edge (Table 27). No use-wear is evident on the flaked edge and no battering marks are present on the cortex-backing. While the specimen is morphologically reminiscent of small wedges, no usewear evidence is present to support this interpretation.

\section{Unmodified Debitage}

A total of 95 unmodified debitage was recovered from shovel testing and excavations associated with the underpinning of the west wall of the southeast gate. The majority $(n=81)$ of these are from the excavations associated with underpinning, although a small number $(\mathrm{n}=14)$ was found during shovel testing. The breakdown of cortex categories among these specimens indicates that tertiary flakes constitute a higher percentage than secondary flakes (Figure 14). Primary flakes are a small portion of the collection. The distribution of debitage by size classes indicates that $11-$ $20 \mathrm{~mm}$ specimens dominate. The $21-30$ and 31-40 $\mathrm{mm}$ size class specimens occur in lower but nearly equal percentages (Figure 15). The smallest size class $(1-10 \mathrm{~mm})$ is under-represented primarily because of the $1 / 4$-inch hardware cloth used in screening the bulk 


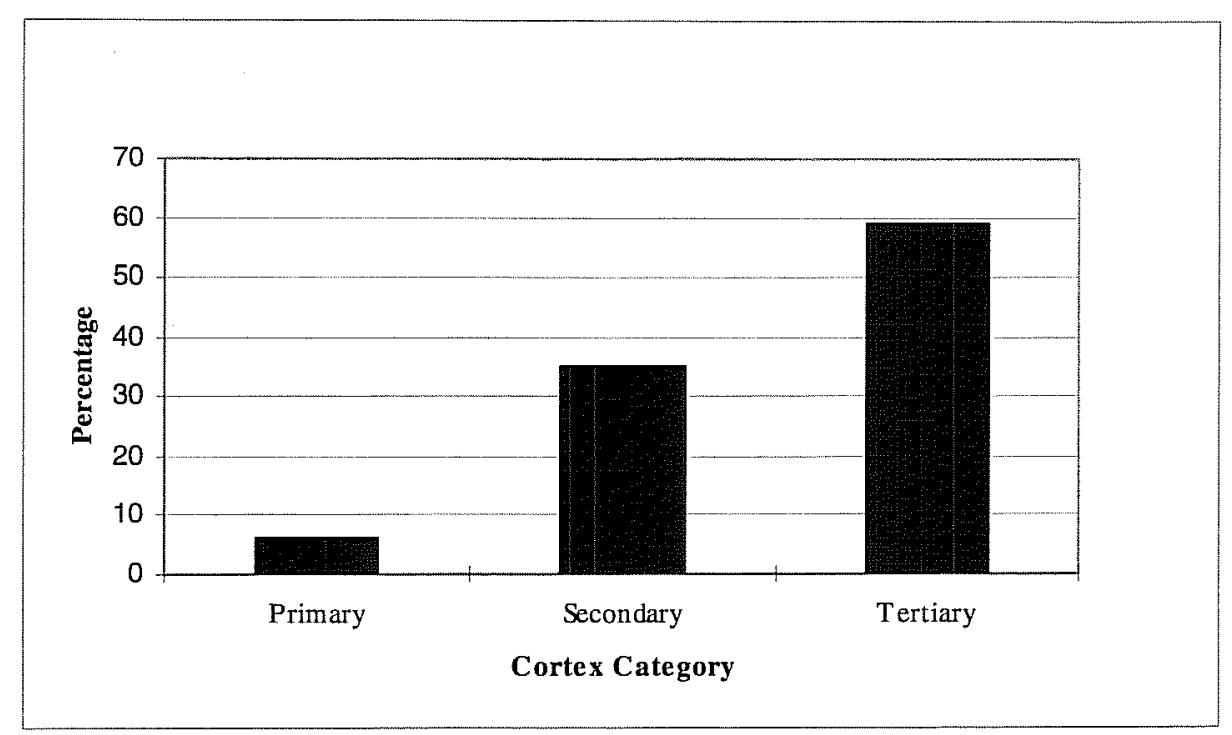

Figure 14. Distribution of debitage by cortex categories.

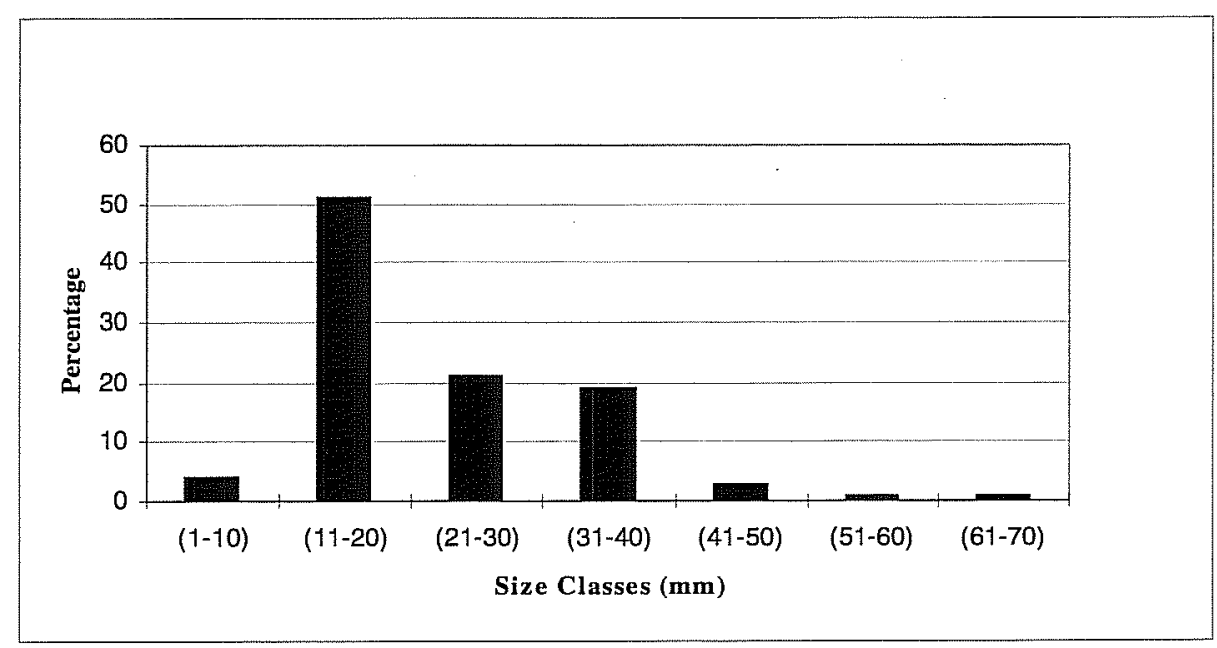

Figure 15. Distribution of debitage by size classes. and San Juan Capistrano (D.E. Fox 1979:Table 2). On the other hand, it stands in strong contrast to debitage collections dominated by bifacial reduction, where multi-faceted striking platforms greatly out number corticate and single faceted specimens (Tomka 1989). The breakdown of the debitage collection in terms of flake type indicates that core/platform preparation flakes constitute the largest proportion of the sample (Figure 17). Given that, as mentioned before, a large proportion of the platformbearing flakes are single faceted or corticate, and many of the specimens have bladelike morphologies, it is likely that most of these flakes derive from the preparation of uni- or bidirectional cores rather bifacial cores (e.g., bifaces). Blades constitute the third largest percentage of debitage, excluding indeterminate flakes. Nonetheless, the scarcity of biface flakes corresponds to the relative emphasis on uni- and perhaps bidirectional blade production at the mission. of the matrix. The percentage of specimens in the larger size classes decreases with increased size. The distribution of platform facet counts indicates that single faceted flakes are the most common among the platform-bearing flakes (complete and proximal fragments, Figure 16). Importantly, corticate platforms are the second most common type. Platform-bearing flakes with two and three or more facets represent a relatively small proportion of the collection. This dominance of corticate and single faceted platform-bearing flakes is similar to platform faceting breakdowns in the debitage from other area missions such as Concepción
Overall, the lithic technology evident in the San Jose lithic artifacts indicates local or nearby raw material procurement, a tool kit composed primarily of expedient scrapers, and the continued manufacture of stone arrow points even though metal points and guns have already been adopted (Tomka and Fox 1998:Figure $14 \mathrm{~g})$. Raw material reduction strategies are dominated by unidirectional or bidirectional core reduction to produce blades and gunflint blanks. Bifacial reduction appears to be employed in arrow point manufacture and the shaping of some gunflint blanks. The tool and debitage assemblage indicates a relative lack of 


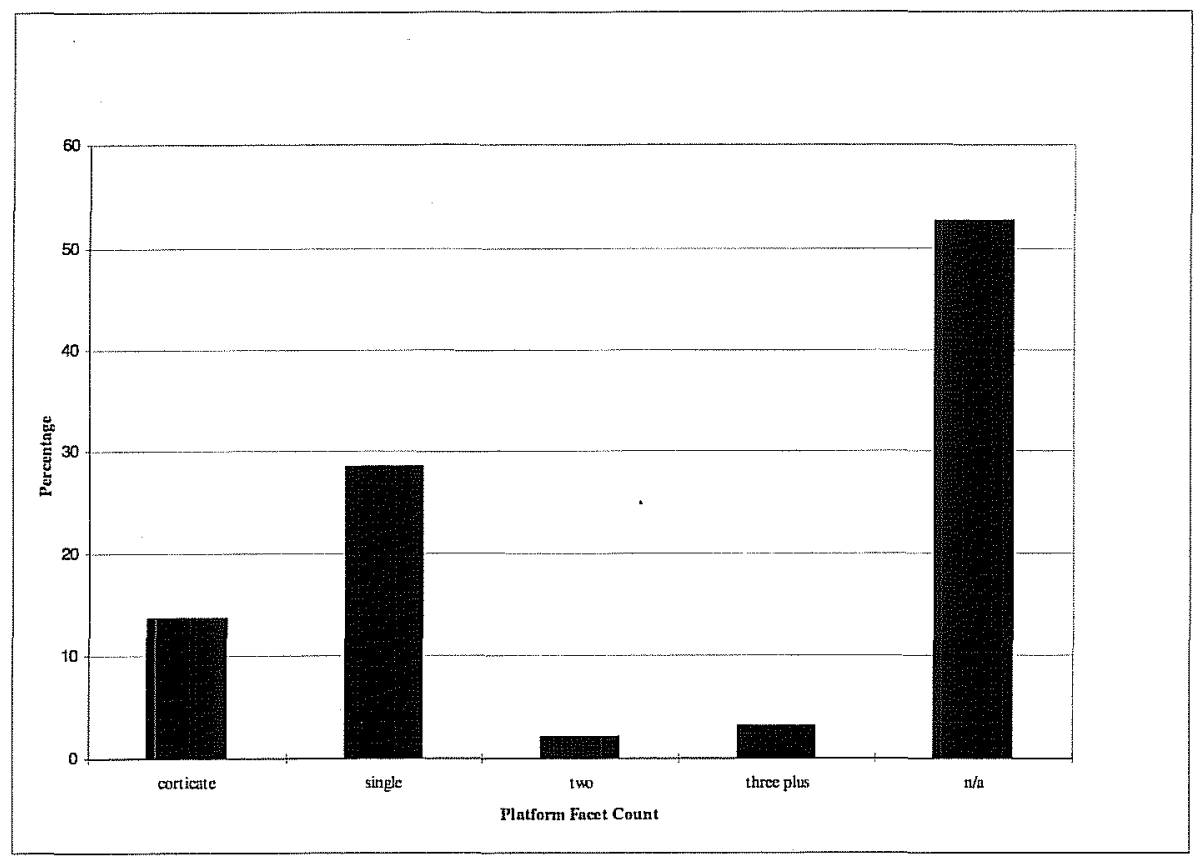

Figure 16. Distribution of platform-bearing flake facet counts.

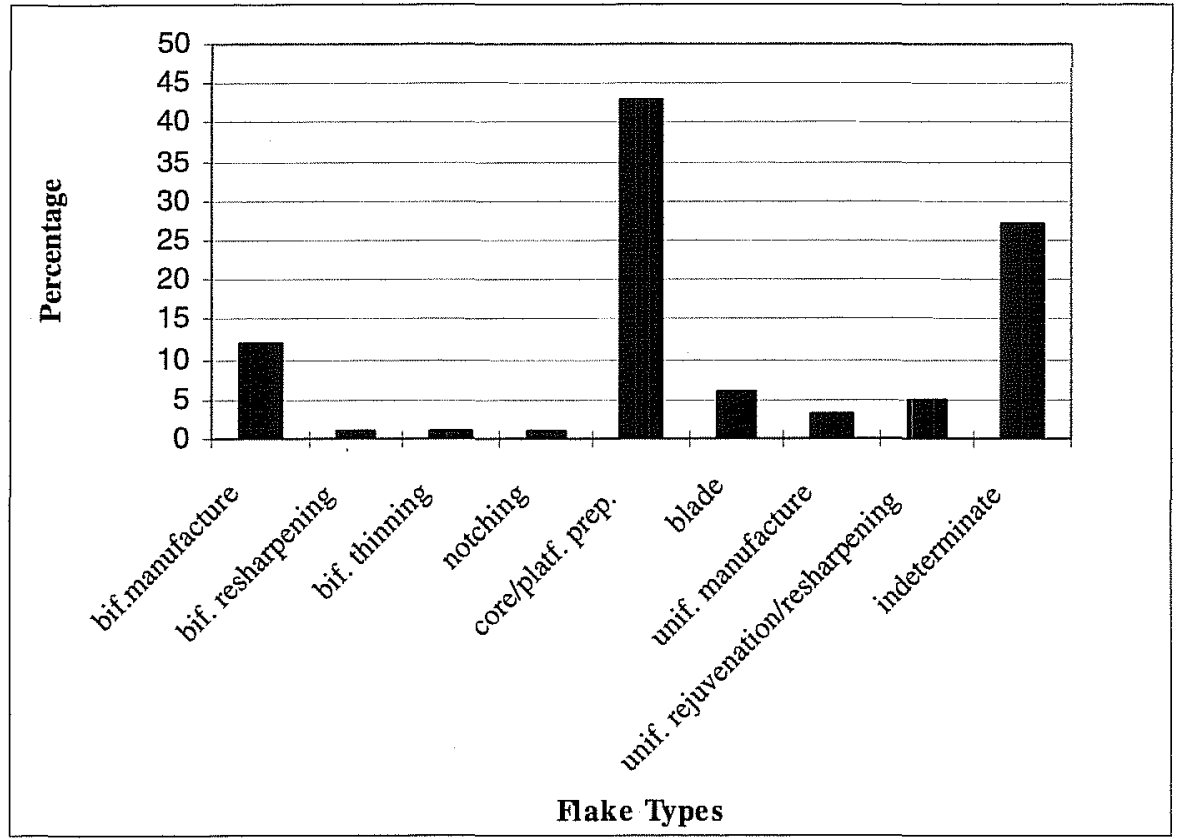

Figure 17. Distribution of debitage by flake type.

bifacial reduction for the manufacture of functional tool classes such as large knives. This assemblage composition pattern may reflect the use, availability, and long use-life of metal knives and a relative lack of raw materials for the manufacture of metal arrow points. 


\section{Vertebrate Faunal Remains}

\author{
Barbara A. Meissner
}

\section{Methods}

A total of 8,731 vertebrate faunal remains, weighing $9,905.28 \mathrm{~g}$, was recovered during the project. The majority of the bones come from excavation units $(n=7,125,82$ percent; see Table 20). In the field bone was recovered by screening sediment through $1 / 4$-inch mesh. Bones were bagged with other artifacts by unit and level. In the laboratory all bone was washed, dried, then bagged by unit and level. The bone was identified to the most specific taxon possible using the comparative collection at CAR, as well as several standard reference texts (Balkwill and Cumbaa 1992; Boessneck 1970, Gilbert 1990; Hildebrand 1955, Hillson 1986; Olsen 1960,1964, 1968; Schmid 1972). Identifications were conservative, that is, bone which appeared to be cow-sized was not identified as Bos taurus unless it could be differentiated from Bison and Equus species. All bone was weighed. Evidence of exposure to heat was noted on all bone. Element, portion of element, side, evidence of immaturity, and kind of breakage were noted on bone identified to the order taxonomic level. The degree of weathering and whether or not bones had been gnawed was noted whenever possible. When bone could be identified only to class (e.g. mammal, bird, etc.) an estimate of the size of the animal was made when possible.

\section{Analysis}

This collection is highly fragmented. The average bone weight for the entire collection was only $1.13 \mathrm{~g}$. Ninety-six percent of the bone could be identified only as mammalian. Only 320 bones ( 3.7 percent) could be identified to the genus taxonomic level. Thirty-three taxa were identified to at least the genus level in the collection. A list of identified taxa from both shovel testing and excavation units is shown in Table 28, with counts and weights.
Cattle dominate the identifiable assemblage, constituting 15.3 percent of the total Number of Individual Specimens (NISP). Goats and sheep were only 4.7 percent, while wild mammals often hunted for food, including deer, rabbit, raccoon, and opossum were almost 21 percent of the total. Birds commonly used as food, such as geese, turkey, and chickens, were 3 percent of the total, and identified fish were 13.45 percent. Identified turtle remains were 16.9 percent of the total NISP. These figures, however, give a false impression of the importance of species with smaller body weight. Bone weight is, in general, a better indicator of relative dietary importance (as opposed to relative abundance) than NISP, but this measure must be used with some caution. In general, larger bones carry more meat, but the relationship is not linear (Reitz and Scarry 1985:18), varies among different taxa, and there is considerable variation from one part of the animal to another (e.g. lower legs of cattle are dense, heavy bones but carry relatively little meat compared to other bones of the body) (Lyman 1994). Table 29 shows the percentage of total NISP weight for each of the categories listed in the paragraph above.

Evidence of exposure to heat can indicate whether bone was routinely thrown into the fire as a disposal method. Only 4.7 percent $(n=414)$ of the bone from this collection showed evidence of heat alteration. Of these, 82.4 percent $(n=341)$ were smoke-stained or charred, while only 17.6 percent $(n=73)$ were partially calcined or calcined. The low percentage of the burned bone that is heavily heat-altered suggests that this area was not used as a dump for burned trash.

Only four bones showed evidence of tooth marks. All four had carnivore tooth marks, which were probably canid. The absence of rodent gnawing and rarity of carnivore gnawing indicates that either a high percentage of the bone was rendered unappealing to rats and dogs (presumably by boiling), or that the bone was buried immediately after disposal, or both.

Weathering data, however, suggests that most of the bone spent at least some time exposed to atmospheric weathering. Only 37 percent $(n=3217)$ of the bone was large enough to observe weathering damage. Of these, 49 percent $(n=1563)$ showed evidence of Stage 1 weathering, i.e., fine longitudinal cracking and rough- 
Table 28. Identified taxa from Mission San José underpinning shovel testing and excavation.

\begin{tabular}{|c|c|c|c|}
\hline Taxa & Common Name & Count & Weight (g) \\
\hline Mammalia & Mammals & & \\
\hline Small Artiodactyl & Deer, sheep, goats & 68 & 150.25 \\
\hline Bos taurus & Cattle & 49 & 913.68 \\
\hline Bovinae & Cattle or bison & 155 & 1400.46 \\
\hline Canis cf. familiaris & Probably dog & 1 & 0.08 \\
\hline Canis sp. & Dog. wolf, or coyote & 3 & 8.36 \\
\hline Capra hircus & Domestic goat & 3 & 8.90 \\
\hline Capra /Ovis & Goat or sheep & 4 & 71.72 \\
\hline Didelphis virginianus & Opossum & 13 & 9.17 \\
\hline Felis cf. domesticus & Domestic cat & 1 & 1.03 \\
\hline Lepus californicus & Blacktailed jackrabbit & 4 & 1.35 \\
\hline Mephitis mephitis & Striped skunk & 7 & 4.97 \\
\hline Neotoma sp. & Woodrats & 8 & 2.21 \\
\hline Odocoileus virginianus & White-tailed deer & 28 & 170.77 \\
\hline Qvis aries & Domestic sheep & 8 & 83.17 \\
\hline Peromyscus sp. & Field mice & 1 & 0.06 \\
\hline Procyon lotor & Raccoon & 2 & 2.18 \\
\hline Rodentia & Rodents & 26 & 4.41 \\
\hline Sciurus sp. & Tree squirrels & 7 & 1.84 \\
\hline Sigmodon hispidus & Cotton rat & 4 & 0.87 \\
\hline Sylvilagus sp. & Cottontail rabbit & 20 & 6.54 \\
\hline Mammal--very small & Rat-sized & 6 & 0.84 \\
\hline Mammal--small & Rabbit-sized & 34 & 8.78 \\
\hline Mammal--medium & Dog-sized & 21 & 22.42 \\
\hline Mammal--1arge & Deer, sheep-sized & 59 & 173.60 \\
\hline Mammal--very large & Cattle, bison, horse-sized & 484 & 2747.40 \\
\hline Mammal & Size indeterminate & 7373 & 3909.16 \\
\hline & Total Mammals & 8389 & 9704.22 \\
\hline Aves & Birds & & \\
\hline Branta sp. & Snow geese & 1 & 1.09 \\
\hline Buteo sp. & Hawks & 1 & 1.23 \\
\hline Gallus domesticus & Chicken & 3 & 0.57 \\
\hline Meleagris gallopavo & Turkey & 5 & 15.04 \\
\hline Turdus migratorius & Robin & 1 & 0.14 \\
\hline Aves--medium & Pigeon-sized & 1 & 0.21 \\
\hline Aves--large & Chicken-sized & 37 & 14.68 \\
\hline Aves--very large & Turkey, hawk-sized & 19 & 18.33 \\
\hline Aves & Size indeterminate & 21 & 5.87 \\
\hline & Total Birds & 89 & 57.16 \\
\hline Reptilia & Reptiles & & \\
\hline Alligator mississippiensis & Alligator & 3 & 6.57 \\
\hline Colubridae & Non-poisonous snakes & 1. & 0.42 \\
\hline Crotalidae & Pit vipers & 3. & 0.95 \\
\hline Crotalus atrox & W.diamondback Rattlesnake & 17 & 5.20 \\
\hline Elaphe sp. & Rat snakes & 30 & 13.31 \\
\hline Lampropeltis $\mathrm{sp}$. & King snakes & 2 & 0.92 \\
\hline
\end{tabular}


Table 28. Continued

\begin{tabular}{|c|c|c|c|}
\hline Pseudomys sp. & Pond sliders & 45 & 55.84 \\
\hline Thamnophis sp. & Garter snakes & 1 & 0.11 \\
\hline Trionyx sp. & Softshelled turtles & 9 & 5.60 \\
\hline Serpentes & Snakes & 4 & 0.76 \\
\hline \multirow[t]{2}{*}{ Testudinata } & Turtles & 21 & 11.85 \\
\hline & Total Reptiles & 136 & 101.53 \\
\hline Osteichthys & Boney Fishes & & \\
\hline Aplodinotus grunniens & Freshwater drum & 2 & 1.40 \\
\hline Ictalurus sp. & Catfish & 17 & 3.98 \\
\hline Lepisosteus sp. & Gars & 14 & 3.13 \\
\hline Pylodictus olivaris & Bullhead catfish & 10 & 9.07 \\
\hline \multirow[t]{2}{*}{ Osteichthys } & Unidentified fish & 46 & 9.85 \\
\hline & Total Fishes & 89 & 27.43 \\
\hline \multirow[t]{2}{*}{ Vertebrata } & Unidentified bone & 28 & 14.94 \\
\hline & Overall Totals & 8731 & 9905.28 \\
\hline
\end{tabular}

ing of the surface texture, while 12 percent $(n=377)$ showed evidence of Stage 2 weathering, with longitudinal cracking both more numerous and deeper, and the beginnings of surface exfoliation. Two bones were Stage 3, with extensive surface exfoliation and splintering of bone. However, of the bone large enough to observe weathering changes, 40 percent $(n=1275)$ appeared to have no exposure to atmospheric weathering (Stage 0).

Using only the bone collection from excavation units as a sample (due to spatial proximity to each other), there was a difference in weathering between bone recovered from inside rooms (i.e., Units 6-8 and 10 15) and bone recovered outside the wall (Units $1-5$ and 16-20). Table 30 shows that the bone outside tended to be more weathered than the bone inside.

Table 29. Percent of total NISP bone weight for selected taxa

\begin{tabular}{|l|r|}
\hline \multicolumn{1}{|c|}{ Taxa Category } & $\begin{array}{r}\text { Percent of Total } \\
\text { NISP Weight }\end{array}$ \\
\hline Cattle & $68.3 \%$ \\
\hline Goats and sheep & $12.2 \%$ \\
\hline Wild mammals hunted for food & $14.3 \%$ \\
\hline Birds used for food & $1.3 \%$ \\
\hline Fish & $1.3 \%$ \\
\hline Turtles & $4.6 \%$ \\
\hline
\end{tabular}

Although this collection is too fragmented to allow useful examination of butchering practices, evidence of butchering and other tool marks were identified on 131 bones ( 1.5 percent). Table 31 lists the type of mark and the number of bones on which the mark was observed. Only three bones (two of which could be conjoined) were found with machine saw cuts, and only 17 (nine of which conjoined) were found with hand saw cuts. About 37 percent $(n=49)$ of the bone which showed butcher marks had been chopped. Twenty-five bones (19 percent) showed evidence of impact fractures, indicating that the bone had been deliberately broken open with a blunt object, presumably a hammerstone.

As mentioned above, nine of the 17 bones that displayed hand saw cut marks were part of a single distal humerus of a cow (Bos taurus). The location of the

Table 30. Comparison of bone weathering inside and outside the South Wall

\begin{tabular}{|l|r|r|r|r|}
\cline { 2 - 5 } \multicolumn{1}{c|}{} & Inside & \multicolumn{1}{c|}{$\%$} & Outside & \multicolumn{1}{c|}{$\%$} \\
\hline Stage 0 & 623 & $56.4 \%$ & 582 & $29.8 \%$ \\
\hline Stage 1 & 422 & $38.2 \%$ & 1076 & $55.2 \%$ \\
\hline Stage 2 & 60 & $5.4 \%$ & 292 & $15.0 \%$ \\
\hline Stage 3 & 0 & $0.0 \%$ & 1 & $0.1 \%$ \\
\hline Totals & 1105 & $100.0 \%$ & 1951 & $100.0 \%$ \\
\hline
\end{tabular}


Table 31. Butcher marks observed on bone

\begin{tabular}{|l|r|}
\hline \multicolumn{1}{|c|}{ Butcher Mark Type } & Count \\
\hline $\begin{array}{l}\text { Thin cut mark. Thin superficial cut, most likely } \\
\text { from a knife. }\end{array}$ & 16 \\
\hline $\begin{array}{l}\text { Thick cut mark. Thicker superficial, from heavy } \\
\text { knife or small hatchet. }\end{array}$ & 16 \\
\hline $\begin{array}{l}\text { Chop mark. Heavy, deep cut that may or may not } \\
\text { have completely severed the bone. }\end{array}$ & 49 \\
\hline Hand saw cut. & 17 \\
\hline Machine saw cut & 3 \\
\hline $\begin{array}{l}\text { Saw cut--indeterminate. Bone is saw cut, but } \\
\text { method used cannot be determined }\end{array}$ & 5 \\
\hline Impact scar. & 25 \\
\hline
\end{tabular}

saw cut was not typical of either nineteenth- or twentieth-century butchering patterns (Lyman 1994). A non-professional butcher may have cut it. Meissner and Hunziker (1997:301-302) found many bones cut in a non-standard fashion in material from a trash pit from the Webb Site (41BX897), located near downtown San Antonio, and suggested that these were the result of home butchering of some of the meat.

\section{Discussion}

The bone in this collection could not, of course, be assigned with certainty to any particular time period in the 200 years during which the mission served as a residential area. Hard et al. (1995:71-80) have shown that animal bone in the San José compound is strongly correlated with colonial period ceramics but not with post-colonial ceramics, suggesting that most of the bone in the mission compound is colonial in origin. The rarity of saw marks is another piece of evidence suggesting that the majority of the bone in this collection was butchered before the mid-nineteenth century.
However, the highly fragmented condition of this collection and the small number of bone which showed any kind of butchering marks (see Table 31) detracts from the force of this observation. Most of the sediments excavated during this project contained artifacts from the colonial period to the twentieth century, indicating there has been considerable disturbance along the south wall. The evidence suggests that the majority of the bone in this assemblage is probably colonial in origin, but some nineteenth- and twentieth-century bone is probably included.

The highly fragmented condition of bone in this collection is a common but not universal finding at San José. Table 32 shows bone counts, weights, and NISP (when available) of bone from several recent excavations: the current project, and four recent excavations at San José (Hard et al. 1995; Hunziker 1998; Meissner 1998a, 1998b). The faunal analyses in several publications of earlier work at San José were examined, but the practice of including bone weight in published reports was not established until recently. However, to provide a sample from the northern part of the compound, bone from test pits excavated in 1978 (Clark 1978) and stored at CAR was recounted and weighed.

Table 32 clearly shows that average bone weight varies a great deal from one area to another at San José. Some of this is probably due to differences in excavation techniques. The data from Hard et al. (1995) is from shovel tests. The data from Meissner (1998b) was excavated during a rainy period, and considerable breakage of wet bone was noted during this excavation.

There are several possible causes for the highly fragmented nature of the collection. Trampling of bone probably contributed to fragmentation (Schiffer 1987:126-127). San José has been in continuous use

Table 32. Comparison of bone counts, weights, and NISP in seven recent excavations at San José, with a sample from an earlier excavation.

\begin{tabular}{|l|r|r|r|r|r|r|r|}
\hline Count & 8,731 & 18,883 & 10,900 & 5.038 & 1,709 & 410 & 204 \\
\hline Weight (g) & $9,905.28$ & $22,847.51$ & $10,205.20$ & $*$ & $5,390.87$ & 832.40 & $1,590.40$ \\
\hline NISP & 320 & 449 & 379 & 161 & 206 & - & - \\
\hline \% NISP & $3.7 \%$ & $2.4 \%$ & $3.5 \%$ & $3.2 \%$ & $12.1 \%$ & - & - \\
\hline Average bone wgt. (g) & $\mathbf{1 . 1 3}$ & $\mathbf{0 . 8 3}$ & $\mathbf{0 . 9 4}$ & $\mathbf{0 . 5 3}$ & $\mathbf{3 . 1 5}$ & $\mathbf{2 . 0 3}$ & $\mathbf{7 . 8 0}$ \\
\hline
\end{tabular}


since it was founded on this location. Foot and vehicle traffic may have caused a great deal of the breakage. Hunziker (1998:26) noted that the bone she examined was much larger and less fragmented than was commonly seen in mission projects in San Antonio, and suggested that most of the bone from that project was located in an area out of normal foot traffic patterns.

Disturbance by construction activities, especially along the south wall, is another source of bone fragmentation. Previous excavations along the south wall (Tomka and Fox 1998) have shown that most of the upper levels along the south wall have been disturbed.

Cultural practices such as shattering of long bones to extract marrow and boiling bone to extract bone grease are probably contributing factors. In order to estimate the amount of breakage due to processing of fresh bone, the type of breaks were noted on long bones from cattle and cattle-sized animals recovered from excavation units. Break categories were: 1) broken while bone was fresh; 2) broken while bone was dry; and 3) exhibiting both break types 1 and 2. Table 33 is a list of the results. A total of 88.9 percent (96/108) had been broken while they were fresh, and 38 percent (41/108) displayed only Type 1 breaks. This sug-

Table 33. Break types on long bone of cow-sized mammals

\begin{tabular}{|c|c|}
\hline Break Type & Count \\
\hline 1 (broken while fresh) & 41 \\
\hline 2 (broken while dry) & 12 \\
\hline Types $1 \& 2$ both present & 55 \\
\hline Tota & 108 \\
\hline
\end{tabular}

gests that a large part of the fragmentation seen in this collection was the result of extensive processing of the bone before deposition.

The extraction of bone grease involves breaking bone, especially vertebra and the ends of long bones, which have a high fat content, into small pieces and then boiling of the bone for an extended period. Bone fat is then periodically skimmed from the surface of the water (Brink 1997: 260; Vehik 1977:171).
The shattering of the bone ends leaves them much less identifiable. The boiling removes nutrients and makes the bone more friable after burial (Nicholson 1996; Vehik 1977:173). The very low numbers of identifiable long bone ends of bovids $(n=8)$, and centrums of vertebra $(n=5)$, and the very high numbers of bone too fragmented to identify even animal size $(n=7373)$ suggest that much of this bone may have been processed to extract bone grease (Vehik 1977:172).

Such heavy processing of bone is not seen universally in colonial sites. The colonial bone bed excavated in 1978 at Mission San Antonio de Valero has an average bone weight of $9.0 \mathrm{~g}$. Most of the long bones have been broken in the middle to extract marrow, but bone ends are largely intact (Meissner 1998c), indicating that processing for bone grease was not carried out. Recent excavations at Mission Nuestra Señora del Refugio (41RF1), in Refugio County, recovered 121,398 pieces of bone, most of which was found in two large trash pits. The average bone weight was 2.97 $\mathrm{g}$ (Tennis, personal communication 1998).

Bone grease is a concentrated food, containing protein and vitamins as well as fat, and has the added advantage of being storable (Vehik 1977:172). Although the amount of fat in an animal varies enormously according to the diet, health, season, and reproductive status, the fat in bone grease is the last to be used for energy during stress (Brink 1997:21). However, the extraction of all available bone grease from bone requires considerable processing time and effort, and fuel for fires to boil the bone (Vehik 1977:170). Human subsistence choices tend to maximize energy capture while maximizing stability of energy capture and minimizing costs (Jochim 1976:16-17). We can assume that if the people at San José were going to the effort of processing the bones of cattle in order to extract bone grease, then they did so because it was the part of an efficient subsistence strategy, given circumstances at the time. In other words, they were going to the trouble of extracting bone grease because they felt it was necessary.

This seems to be in contradiction with the glowing reports from missionaries concerning the production of food. Records from the mission at San José seem 
to indicate that both farming and herding were very successful (Habig 1978:101, 134, 157, 211), so much so that they were able to send some of the harvest to other missions (Habig 1978:157). Stock brought to Mexico and later to Texas had proven that northern New Spain was ideal cattle country. Herds increased quickly, with or without close supervision by humans (Graham 1994:12). Irrigated fields at the missions produced good quantities of corn and other foods even during dry periods (Habig 1978:101, 134, 157, 211).

The missionaries were well aware that food was the best inducement they had to encourage Native Americans to join a mission, and to stay in the mission. One report from 1785 stated that Native Americans "learn the faith through the mouth rather than through their ears, and are moved more by gifts than by the strongest and clearest reasoning" (Dabbs 1991:458). Accordingly, missionaries were very careful to provide as much meat, as well as other foods, as possible. Guidelines written for missionaries about 1760 advised, "Every week the missionary must see to it that the supply of beef cattle are brought to be rationed for the sustenance of the Indians. . . Generally, four or six are slaughtered when the natives are few" (Leutenegger 1976:19). Fr. Ildefonso Marmolejo, in October 1755 , noted that "for the weekly ration 7 beef cattle are slaughtered, 4 for those living at the mission, 1 for the shepherds, 1 for the cowboys, and 1 which is made into jerked meat for the convalescents. Chicken and mutton are also given to the sick" (Habig 1978:135). The population of Native Americans at San José at the time of this report was 194 (Habig 1978:122). Even assuming that the cattle in question were small and fairly lean, this suggests that an enormous quantity of beef was being consumed, even without including other meat sources, such as sheep, goats, pigs, and non-domesticated animals. It does not seem that the heavy processing seen in the bone from this collection would be necessary.

However, between 1749 and 1784, the reports estimating herd size indicate a steady decline in the number of cattle available to the mission, with a sharp drop after 1767 (Hard et al. 1995:81). One report from 1785 laments:
In the past the income from the herds and the missionaries' allowance alone was enough to clothe the Indians and pay the expenses of the Divine Cult, now without [the herds], there is not enough for either. As a result ... these wretches are made to suffer and endure great sorrow, while they observe that the Apaches are allowed ... to cause excessive damages to their cattle, and that the soldiers and citizens are permitted to slaughter them (Dabbs 1991:453).

While this statement was part of a plea for a change in policy, and can be assumed to be somewhat exaggerated, there is no question that cattle populations were dwindling as the end of the eighteenth century approached. By 1794, the drop in the cattle population was becoming severe. Governor Muñoz imposed a quota on cattle that could be slaughtered for family needs and banned the slaughter of breeding cows (de la Teja 1995:111), and in 1803 Governor Elguézabal reported "There is a notable scarcity of cattle" (de la Teja 1995:112).

There are probably several reasons for this decline in cattle population. One may have been environmental. Tree ring data from East Texas shows that the period between about 1770 and 1810 was unusually dry, with only two relatively wet years during the entire period (Stahl and Cleaveland 1988). This drought could have resulted in a severe food shortage for the cattle. Evidence that this is at least part of the problem is the report from San José in 1785 which indicated that after considerable effort on the part of the vaqueros at the mission ranch, only 682 cattle were rounded up, which "were all very lean. In the end it was necessary to set them loose. Things were so bad that by the present time many may have already died" (Habig 1978:244).

Another reason for the decline of cattle may have been increase in predation by all the inhabitants of the area. The Apaches and other hostile native groups had been a serious drain on the cattle population from the beginning (Habig 1978). The non-mission population of the valley was growing, and by the 1770 s, more and more of them were using cattle not only for food but also for the production of commercial products such as soap, tanned hides, and tallow (de la Teja 1995:110). 
In addition, an estimated 18,000 cattle were rounded up and driven south to Coahuila and Nuevo Santander between 1779 and 1786 (de la Teja 1995:111).

The Spanish authorities decided that the Crown should have a piece of this enterprise. In 1777, the Commander General of the Province, Teodoro de la Croix, declared that all wild or unbranded cattle belonged to the royal treasury (Dabbs 1991:446), and henceforth a license must be obtained and a fee paid for slaughter of such cattle. Lacking the manpower to keep their herds properly branded, combined with the long-term drought conditions, continuing theft by Apaches, and competition from the civilian community, the missionaries found feeding their charges a problem for the first time since the founding of the missions (Dabbs 1991:453).

Hunting of wild animals to supplement domestic meat supplies would have been limited due to almost constant danger from attack by Apache and Comanche raiders. Numerous complaints from the missionaries make it clear that this was a very real danger. One report from 1740 noted: "This Apache tribe is so numerous, haughty, and daring and their insolence has become so great that they now go as near as Quaguila, killing and robbing whomever they meet. Therefore, out of fear of them, no one dares travel along the roads" (Habig 1978:86). In any case, the drought conditions would have made wild game as scarce and lean as the cattle.

Historic evidence suggests that although the fields and herds of the mission provided plentiful food, meat shortages did occur. Extracting every bit of available energy from the carcasses of the animals they did have would have become more important during those times. Even though the cattle may have been very lean during these times, the bone grease could have provided a small but important resource. As Brink (1997:271) notes "At such times the mobilization of standard carcass reserves coupled with the stability of bone fat, would elevate the proportion that grease contributes. . . These condition could warrant the considerable labour required for grease rendering."

\section{Conclusion}

The degree of fragmentation of bone from this project makes assessment of the assemblage somewhat problematic. Cattle dominate the identifiable assemblage, with deer the next most abundant (Table 28). Small domestic artiodactyls such as goats and sheep are present in small numbers. Only a few birds and fish bones were identified. Turtles were fairly common, but provide only a small part of the total weight.

The bones represent a meat diet consisting mostly of beef augmented by hunted animals, sheep, and goats. Only a few bones each of the remaining identified taxa were present. The pattern is similar to that seen in faunal assemblages from recent excavations at San José. Like most of the bone excavated along the south wall at San José, the collection is highly fragmented (Meissner 1998a, 1998b). Possible reasons for this include excavation techniques, disturbance by construction, trampling, and processing of bone for extraction of bone grease. The relative absence of long bone ends and centrums of vertebrae and the high numbers of small, unburned fragments of bone suggest that much of the bone was processed for bone grease (Vehik 1977:172).

Although archival reports indicate that, in general, food supplies at the mission were ample for feeding the neophytes, there is some evidence that at times cattle populations were inadequate. At these times there would have been limits on the degree to which wild animals could have been used to supplement domestic animals because of the dangers that Apache and Comanche raiding presented. It is possible, then, that the bone from this collection, as well as other highly fragmented bone from San José, was deposited during a period when the nutritional value of bone grease was considered important enough to justify the cost in labor and resources needed to acquire it. Two such periods in the history of the mission are likely. One would have been when the mission was first established, before mission herds had been developed and Native Americans trained in their management. The second period would have been in the last years of the eighteenth century, just before secularization, when reports indicate that there was a serious decline of cattle populations in general and mission cattle in particular. 


\section{Shell}

A total of 87 mussel and snail shells were recovered. Only ten of these come from shovel testing. Fifty-three fragments of river mussel shell were found in excavation units. Shell fragments like these are often found in colonial deposits at all the missions.

\section{Summary and Recommendations}

In October 1997 extensive shovel testing was carried out by CAR personnel at Mission San José y San Miguel de Aguayo in preparation for grade alterations to be undertaken along the exterior and interior walls of the mission compound. In June and late July 1998, CAR personnel conducted additional excavations adjacent the south wall and within Room 54 adjacent the western corner of the southeast gate. These excavations were undertaken to mitigate the impact of underpinning efforts of the southwest comer of the southeast gate.

The shovel testing had two general goals: to ascertain the presence and depth at which cultural materials occurred around the east, west, and south sides of the mission; and to determine the age of the cultural materials that may be impacted by the grade alteration activities. The archaeological excavation associated with the underpinning was to recover all cultural materials impacted by these construction activities and obtain a sample of the colonial foundation.

Eleven shovel tests (Nrs. 1-4; 13-19) were excavated along the south wall of the mission at a distance of 9 to 50 feet from the wall. As per the scope of work, all units were excavated to a depth of 12 inches bs. The vertical distribution of temporally diagnostic colonial and of post-1800s ceramics indicates the presence of mixed deposits containing relatively recent artifacts. Shovel Tests 2, 3, and 14, revealed a sterile road base gravel layer further substantiating the mixed nature of the deposits. Based on more extensive and deeper excavations conducted by CAR personnel in June and September 1997 (Tomka and Fox 1998), in conjunction with the data from these 11 shovel tests, it is concluded that less-disturbed deposits containing a greater proportion of pre-1800s or colonial materials may be found along the south wall of the mission but only at a depth greater than 12 inches below surface.

Fifteen shovel tests (Nrs. 9-12; 29-39) were excavated along the east wall of the mission ranging from 7 to 40 feet from the wall. The relative abundance of colonial period ceramics as well as bone in ST 11 at a distance of 40 feet from the wall suggests the possibility that this may be the location of a midden deposit associated with the Indian Quarters. The materials observed in the remaining shovel tests indicate that the 12 inches sampled represent mixed deposits derived from previous landscape work and grade adjustments in the area. This is particularly true of the deposits found along the southern half of the east wall and within 15 feet of the base. It appears that deposits from 65-85 feet from the wall were bladed against its base to provide the necessary grade. It is likely that less-disturbed cultural deposits dating to the colonial period are found near the present surface some 65-85 feet from the wall. Cultural material found along the northern half of the east wall consists of mixed latenineteenth- and twentieth-century remains. These remains derive from former structures and trash dumps dispersed at the time these features were leveled. The shovel testing results suggest that intact colonial deposits may be present in this area at a depth greater than 12 inches bs.

Thirteen shovel tests (Nrs. 5-8; 20-28) were excavated along the west wall of the mission. They ranged from 9 to 50 feet from the base of the wall. Based on the data from these 13 shovel tests, in conjunction with more extensive and deeper excavations (Units 12 and 15) conducted by CAR personnel in September 1997 (Tomka and Fox 1998), it is suggested that less-disturbed deposits containing a greater proportion of pre1800 s or colonial materials may be found along the west wall of the mission but only at a depth greater than 12 inches bs. Care should be exercised in the vicinity of the air conditioner platform to keep subsurface disturbance at a minimum below the present ground surface adjacent to ST 7 . The presence of a large quantity of animal bone recovered from ST 7, suggests the presence of a midden in the area (Schuetz 1970). Based on this likelihood, it is possible that subsurface disturbances extending more than 9 inches below the present surface in the vicinity of ST 7 might disturb cultural materials of potential significance. 
Excavations associated with the underpinning of the southeast gate concentrated in three areas: inside of Room 54; outside Room 54 along the south wall; and outside along the west wall of the southeast gate. Of the eight units excavated along the interior south and east walls of Room 54, three units $(10,11$, and 13) uncovered remnants of a plastered colonial floor of the Indian Quarters at a depth of 21.5 inches bs. In addition, Unit 12, excavated in the fall of 1997, also revealed the powdery orangish-yellow matrix in Level 4 (18-24 inches bs) at a depth of between 20.5-22 inches bs. Remnants of the Indian Quarters floor were not found in other units due to disturbance from CWA efforts to relocate the colonial foundation.

Ten units were excavated outside along the mission's south wall (Nrs. 1-5, 16-20), immediately adjacent the corner of the gate (Figure 3). Six units (Nrs. 1-5, 16) were positioned immediately against the base of the wall. Four additional 3'-x-3' units (Nrs. 17-20) were excavated three feet from the wall and contiguous with the westernmost four units. The excavations of the first six units revealed that between a third to a half of the area of each 3 '-x-3' unit is heavily disturbed by CWA attempts to locate and trace the original colonial foundation of the Indian Quarters. Although the utilization of a mix of artificial and natural excavation levels does aid in reducing the mixture of colonial and post-colonial materials, few undisturbed deposits can be found in a strip ranging from 12 to 18 inches from the base of the CWA wall. The excavations of the four units lying three feet removed from the base of the mission wall (Units 17-20) confirmed that deposits found 18-24 inches bs (Level 2) contain primarily colonial materials and only the upper 1-3 inches of deposits in Level 3 (24-30 inches bs) contain material remains. A concrete footing for a rectangular 4"-x-4" post was encountered in Unit 16 along the outside of the south wall adjacent the southwest corner of the gate. This find suggests that as part of the original CWA reconstruction 4 "-x-4" posts set in concrete may have supported a gate placed on the outside of the entryway to the mission. It is not known whether this outside gate would have represented a second gate or a modification in the location of the presently used gate. It is further unclear if this find represents a modification of plans whether it occurred during the CWA construction or sometime there after.
Two units (Units 14 and 15) were excavated along the west wall of the southeast gate. The excavation of Unit 15 revealed a portion of the colonial living surface uncovered within Room 54 . The remnants of the living surface were found at a depth of 21 inches bs. The living surface continues eastward under the unexcavated portion of the southeast gate indicating that the Indian Quarters continued in the area of the present gate.

Overall, based on the results of these excavations, it is concluded that less-disturbed colonial deposits may be found along the south and west walls of the mission but only at a depth greater than 12 inches bs. On the other hand, colonial-age deposits may be found near the surface along the southern half of the east wall at a distance of 65-85 feet from the base of the wall. Materials recovered from STs 11 and 7, along the east and west walls of the mission, respectively, suggest the presence of colonial midden deposits. An area measuring approximately $25-30$ meters in diameter, centered on these units, should be protected from disturbance until future investigation of these areas is feasible. Excavations associated with the underpinning of the southeast gate identified the remnants of a colonial floor inside the Indian Quarters rooms (Room 54 and room where present gate is standing). Future excavations within additional Indian Quarters rooms should be prepared to encounter and investigate additional remnants of the colonial living surface. 



\section{References Cited}

Angione, G.

1973 All Bisque and Half-Bisque Dolls. Thomas Nelson, Nashville, Tennessee.

Balkwill, D. M. and S. L. Cumbaa

1992 A Guide to the Identification of Postcranial Bones of Bos taurus and Bison bison. Canadian Museum of Nature, Ottawa.

Barnes, M. R.

1980 Mexican Lead-Glazed Earthenwares. In Spanish Colonial Frontier Research, compiled and edited by Henry F. Dobyns. Spanish Borderlands Research, No. 1. Center for Anthropological Studies, Albuquerque.

Boessneck, J.

1970 Osteological Differences Between Sheep (Ovis aries Linné) and Goats (Capra hircus Linné). In Science in Archaeology, edited by D. Brothwell and E. Higgs, pp. 331-358. Praeger, New York.

Brink, J. W.

1997 Fat Content in Leg Bones of Bison bison, and Applications to Archaeology. Journal of Archaeological Science 24:259-274.

Charlton, T. H. and R. R. Katz

1979 Tonalá Bruñida Ware, Past and Present. Archaeology 32 (1).

Clark, J. W., Jr.

1978 Mission San José y San Miguel de Aguayo: Archeological Investigations, December 1974. Archeological Report 29. Texas Historical Commission, Austin.

Clark, J. W., Jr. and A. M. Juarez

1986 Urban Archeology: A Culture History of a Mexican-American Barrio in Laredo, Webb County, Texas. Vol.1. Publications in Archeology. Report 31. Texas State Department of Highways and Public Transportation, Highway Design Division, Austin.

Clark, J. W.,Jr. and E. J. Prewitt

1979 Archeological Test Excavations in Areas to be Affected by a Proposed French Drain West of the Granary, Mission San José State Historic Site (41BX3), Bexar County, Texas. Reports of Investigations 3. Prewitt and Associates, Inc., Austin.

Dabbs, J. Autrey (translator)

1991 The Texas Missions in 1785. In Spanish Borderlands Sourcebooks, No. 22: Documentary Evidence for the Spanish Missions of Texas, edited by Arthur R. Gomez. Garland Publishing, New York.

de la Teja, J. F.

1995 San Antonio de Béxar: A Community of New Spain's Northern Frontier. University of New Mexico Press, Albuquerque. 
Folan, W. J., I. W. Cox, A. A. Fox, and G. M. Hinojosa

1986 Laredo, Texas: A Gateway Community on the Texas Borderlands. Archaeological and Historical Investigations for the Laredo City Toll Plaza (41WB36, 37, and 38). Archaeological Survey Report 116. Center for Archaeological Research, The University of Texas at San Antonio.

Fox, A. A.

1974 Lead Glazed Wares. In Mission Rosario Archeological Investigations 1973, edited by K. Gilmore, 1:55-60. Archeological Report 14. Texas Parks and Wildlife Department, Historic Sites and Restoration Branch, Austin.

1998 Stoneware Potteries in the San Antonio Area. Presentation at "From the Land -19th Century Texas Stoneware Seminar." National Wildflower Reseạch Center, Austin.

Fox, A. A., F.A. Bass, Jr., and T. R. Hester

1976 The Archaeology and History of Alamo Plaza. Archaeological Survey Report 16. Center for Archaeological Research, The University of Texas at San Antonio.

Fox, A. A. and I. W. Cox

1991 Testing of the San José Mission Acequia, San Antonio Missions National Historical Park, Bexar County, Texas. Archaeological Survey Report 207. Center for Archaeological Research, The University of Texas at San Antonio.

Fox, D. E.

1970 Archeological Salvage at Mission San José, December 1969 and August 1970. Archeological Report 3. Texas Historical Survey Committee, Austin.

1979 The Lithic Artifacts of Indians at the Spanish Colonial Missions, San Antonio, Texas. Special Report, No. 8. Center for Archaeological Research, The University of Texas at San Antonio.

Gerald, R. E.

1968 Spanish Presidios of the Late Eighteenth Century in Northern New Spain. Museum of New Mexico Research Records No. 7, Museum of New Mexico Press, Santa Fe.

Gilbert, B. M.

1990 Mammalian Osteology. Missouri Archaeological Society, Columbia, Missouri.

Goggin, J. M.

1968 Spanish Majolica in the New World, Types of the Sixteenth to Eighteenth Centuries. Yale Publications in Anthropology 72. Department of Anthropology, Yale University.

Graham, J. S.

1994 El Rancho in South Texas: Continuity and Change from 1750. University of North Texas Press, Denton.

Habig, M. A.

1968a The Alamo Chain of Missions. A History of San Antonio's Five Old Missions. Franciscan Herald Press, Chicago, Illinois.

1968b San Antonio 's Mission San José. State and National Site 1720-1968. Naylor, San Antonio. 
Habig, M. A., compiler

1978 The San José Papers: The Primary Sources for the History of San José y San Miguel de Aguayo from Its Founding in 1720 to the Present. Part I:1719-1791. Translated by B. Leutenegger et al. Old Spanish Missions Historical Research Library at Mission San José, San Antonio.

Hard, R. J., A. A. Fox, I.W. Cox, K. J. Gross, B. A. Meissner, G. I. Méndez, C. L. Tennis, and J. E. Zapata 1995 Excavations at Mission San José y San Miguel de Aguayo, San Antonio, Texas. Archaeological Survey Report, No. 218. Center for Archaeological Research, The University of Texas at San Antonio.

Henderson, J. and J. W. Clark, Jr.

1984 Test Excavations at the Acequia and Other Features a Mission San José, Bexar County, Texas. Publications in Archaeology Report 25. State Department of Highways and Public Transportation, Highway Design Division, Austin.

Hildebrand, $M$.

1955 Skeletal Differences Between Deer, Sheep, and Goats. California Fish and Game 41:327-346.

Hillson, Simon

1986 Teeth. Cambridge University Press, Cambridge.

Hunziker, J. M.

1998 Faunal Analysis. In Investigations of the Southeast Gateway at Mission San José, Bexar County, Texas, by C. L. Tennis, pp.22-26. Archaeological Survey Report No. 252, Center for Archaeological Research, The University of Texas at San Antonio.

Jochim, M. A.

1976 Hunter-Gatherer Subsistence and Settlement: A Predictive Model. Academic Press, New York.

Leutenegger, Fr. B. (editor and translator)

1976 Guidelines for a Texas Mission: Instructions for the Missionary of Mission Concepción in San Antonio. Old Spanish Missions Historical Research Library, Mission San José, San Antonio, Texas.

Leutenegger, Fr. B., Fr. M. A. Habig, and M. C. Casso

1978 The San José Papers. Part I: 1719-1791. Old Spanish Missions Historical Research Library, Mission San José, San Antonio, Texas.

Lister F. C. and R. H. Lister

1974 Maiolica in Colonial Spanish America. Historical Archaeology 8:17-52.

Lymain, R. L.

1994 Vertebrate Taphonomy. Cambridge University Press, Cambridge. 
Meissner, B. A.

1997 Dolls, Toys, Games, and Other Diversions. In Archaeology at the Alamodome: Investigations of a San Antonio Neighborhood in Transition, Volume III, Artifacts and Special Studies, edited by Anne A. Fox, Marcie Renner, and Robert J. Hard. Archaeological Survey Report 238. Center for Archaeological Research, The University of Texas at San Antonio.

1998a Vertebrate Faunal Remains. In Mission San José Indian Quarters Wall Base Project. Bexar County, Texas. Archaeological Survey Report No. 278. Center for Archaeological Research, The University of Texas at San Antonio.

1998b Vertebrate Faunal Remains. In Archaeological Investigations of Rainwater Catchment Basins along the South Wall of Mission San José, San Antonio, Texas. Archaeological Survey Report No. 287. Center for Archaeological Research. The University of Texas at San Antonio.

1998c Analysis of Vertebrate Faunal Remains from a Spanish Colonial Mission, San Antonio de Valero (the Alamo), Bexar County, Texas. Unpublished Master's Thesis on file at the Center for Archaeological Research, The University of Texas at San Antonio.

Meissner, B. A. and J. M. Hunziker

1997 Analysis of the Vertebrate Faunal Remains from the Alamodome Project.. In Archaeology at the Alamodome: Investigations of a San Antonio Neighborhood in Transition, Volume III, Artifacts and Special Studies, edited by Anne A. Fox, Marcie Renner, and Robert J. Hard. Archaeological Survey Report 238. Center for Archaeological Research, The University of Texas at San Antonio.

Nicholson, R. A.

1996 Bone Degradation, Burial Medium and Species Representation: Debunking the Myths, and ExperimentBased Approach. Journal of Archaeological Science 23:513-533.

Olsen, Stanley J.

1960 Post-Cranial Skeletal Characters of Bison and Bos. Peabody Museum, Cambridge, MA.

1964 Mammal Remains from Archaeological Sites Part I; Southeastern and Southwestern United States. Peabody Museum, Cambridge.

1968 Fish, Amphibian, and Reptile Remains from Archaeological Sites Part I: Southeastern and Southwestern United States. Peabody Museum, Cambridge.

Reitz, E. J., and C. M. Scarry

1985 Reconstructing Historic Subsistence, with an Example from Sixteenth-Century Spanish Florida. Special Publication No. 3, Society for Historical Archaeology, Ann Arbor, MI.

Roberson, W., and T. W. Medlin

1976 San José Mission State Historic Site, Archeological Testing 1974 and 1976. Compiled and edited by J. David Ing. Archeological Report 23. Texas Parks and Wildlife Department, Historic Sites and Restoration Branch.

Roycroft, D. and C. Roycroft

1975 American Country Pottery. Wallace-Homestead Book Company, Des Moines, Iowa.

Schiffer, M. B.

1987 Formation Processes of the Archaeological Record. University of New Mexico Press, Albuquerque.

Schmid, E.

1972 Atlas of Animal Bones for Prehistorians, Archaeologists, and Quaternary Geologists (Knochenatlas Für Prähistoriker; Archäologen und Quartärgeologen). Elsevier Publishing, Amsterdam. 
Schuetz, M. K.

1968 The History and Archeology of Mission San Juan Capistrano, San Antonio, Texas. Vol. I. Report 10. State Building Commission Archeological Program, Austin.

1969 The History and Archeology of Mission San Juan Capistrano, San Antonio, Texas. Vol. II. Report 11. State Building Commission Archeological Program, Austin.

1970 Excavation of a Section of the Acequia Madre in Bexar County, Texas, and Archeological Investigations at Mission San José in April 1968. Archeological Report 19. Texas Historical Survey Committee, Austin.

Stahl, D. W. and M.K. Cleaveland

1988 Texas Drought History Reconstructed and Analyzed from 1698 to 1980. Journal of Climate 1:59-74.

Tennis, C. L.

1997 Investigations of the Southeast Gateway at Mission San José, Bexar County, Texas. Archaeological Survey Report 252. Center for Archaeological Research, The University of Texas at San Antonio.

Tomka, Steve A.

1989 Differentiating Lithic Reduction Techniques: An Experimental Approach. In Experiments in Lithic Technology, edited by Daniel S. Amick and Raymond P. Mauldin, pp. 137-161. BAR International Series 528 .

Tomka, Steve A., and Anne A. Fox

1998 Mission San José Indian Quarters Wall Base Project. Bexar County, Texas. Archaeological Survey Report No. 278. Center for Archaeological Research, The University of Texas at San Antonio.

1999 Archaeological Investigations of Rainwater Catchment Basins along the South Wall of Mission San José, San Antonio, Texas. Archaeological Survey Report No. 287. Center for Archaeological Research. The University of Texas at San Antonio.

Turner, Ellen Sue, and Thomas R. Hester

1993 A Field Guide to Stone Artifacts of Texas Indians. Second Edition. Texas Monthly Field Guide Series, Gulf, Houston.

Vaughan, M.

1997 Kitchen Utensils and Tablewares. In Archaeology at the Alamo Dome: Investigations of a San Antonio Neighborhood in Transition, edited by Anne A. Fox. Marcie Renner, and Robert J. Hard. Vol III Artifact and Special Studies, pp. 209-228. Archaeological Survey Report 238. Center for Archaeological Research, The University of Texas at San Antonio.

Vehik, S. C.

1977 Bone Fragments and Bone Grease Manufacturing: A Review of Their Archaeological Use and Potential. Plains Anthropologist 22:169-182.

Yeoman, R. S.

1967 A Guide Book of United States Coins. 20th Edition. Whitman Publishing Company, Racine, Wisconsin.

Zapata, J.E.

1997 Alamodome and Abroad: A Composite Inquiry on Toy Marbles. In Archaeology at the Alamo Dome: Investigations of a San Antonio Neighborhood in Transition, Volume III, Artifacts and Special Studies, edited by Anne A. Fox, Marcie Renner, and Robert J. Hard. Archaeological Survey Report 238. Center for Archaeological Research, The University of Texas at San Antonio. 



\section{Appendix 1}

San Antonio Missions Signage Removal and Installation Project:

Shovel Testing and Monitoring at Missions San José, San Juan, Concepción, and Espada.

By Jeffrey J. Durst 



\section{Appendix I}

\section{San Antonio Missions Signage Removal and Installation Project: Shovel Testing and Monitoring at Missions San José, San Juan, Concepción, and Espada}

\author{
by Jeffrey J. Durst
}

\section{Introduction}

Center for Archaeological Research (CAR) personnel undertook shovel-test excavations and monitoring of machine-bored holes at missions San José, San Juan, Espada, and Concepción during August 1998. These tests were conducted in preparation for the installation and relocation of eleven signs located within the San Antonio Missions National Historical Park.

These activities consisted of the excavation and monitoring of a total of 22 holes (four hand-excavated shovel tests, excavated in 6-inch arbitrary levels, and 18 machine-bored holes, excavated in one level) and the monitoring of the removal of four existing signs. The soil matrix from all holes bored was screened through 1/4-inch mesh to inspect for cultural remains. The soil matrix exhumed by the four relocated signs was visually inspected.

The fieldwork was carried out over a two-day period by a crew of two individuals. Serving as principal and co-principal investigators were Robert J. Hard and C. Britt Bousman, respectively. The project archaeolo- gist was Jeffrey J. Durst, who worked with the field assistance of Clemente Murguia.

\section{Scope of Work}

According to National Park Service (NPS) plans, the installation of 10 signs at the four missions necessitated the excavation of 20 individual holes (2/sign) measuring 8 inches in diameter. The removal of 4 existing signs necessitated the reopening of an additional 8 holes. Finally, the relocation of one of the signs removed at Mission Concepción, needed the excavation of an additional pair of holes. In summary, 22 new holes were to be excavated in conjunction with the installation of 11 signs, and 8 existing holes were to be re-excavated to remove 4 signs. These excavations were to extend no deeper than 24 inches below surface.

To mitigate the impact of these activities, CAR personnel recommended the hand excavation of 4 shovel tests, one per sign, in conjunction with the installation of signs 3, 4, 6, and 6a at Mission San José (Figure 1-1). These signs were to be located in areas judged to have high potential for intact archaeological deposits based on previous work at the mission (Hard et al. 1995). CAR also proposed the screening of the material from all auger excavated-holes $(\mathrm{n}=18)$ associated with signage installation/relocation. The re-excavation of the 8 existing holes associated with signage removal was to be visually monitored for the presence of artifacts and features. The soil matrix from all shovel tests, including the 18 machine bored holes was screened through $1 / 4$-inch mesh to search for cultural materials and all holes were visually inspected for possible features.
Table 1-1. Artifacts from shovel tests at Mission San José

\begin{tabular}{|l|c|c|c|c|c|r|}
\hline $\begin{array}{c}\text { Shovel } \\
\text { Test/Level }\end{array}$ & Ceramics & $\begin{array}{c}\text { Misc. } \\
\text { Metal }\end{array}$ & $\begin{array}{c}\text { Misc. } \\
\text { Glass }\end{array}$ & $\begin{array}{c}\text { Constr. } \\
\text { Material }\end{array}$ & $\begin{array}{c}\text { Animal } \\
\text { Bone }\end{array}$ & Totals \\
\hline ST2/L3 & 1 & & 1 & & & 2 \\
\hline ST2/L4 & & 2 & 1 & & 1 & 3 \\
\hline ST3/L1 & & & & & 4 & 0 \\
\hline ST4/L1 & 1 & & & & 3 & 1 \\
\hline ST4/L2 & 2 & 2 & & 1 & 2 & 5 \\
\hline ST4/L3 & 2 & & & & & 2 \\
\hline Totals & 6 & 4 & 2 & 1 & 10 & 13 \\
\hline ST1 was & & & & & & \\
\hline
\end{tabular}

ST1 was assoc. w. Sign 3; ST2 was assoc. w. Sign 4; ST3 was assoc. w. Sign 5; ST4 was assoc. w. Sign $6 a$.

\section{Results of Investigations}

\section{Shovel Tests At Mission San José}

Four shovel tests (Nos. 1-4) were excavated in conjunction with the installation of signs 3,4 , 6 , and 6a, respectively (Figure 1-1). These shovel tests were excavated in arbitrary 6 -inch levels. Table 1-1 presents the artifact categories and the 


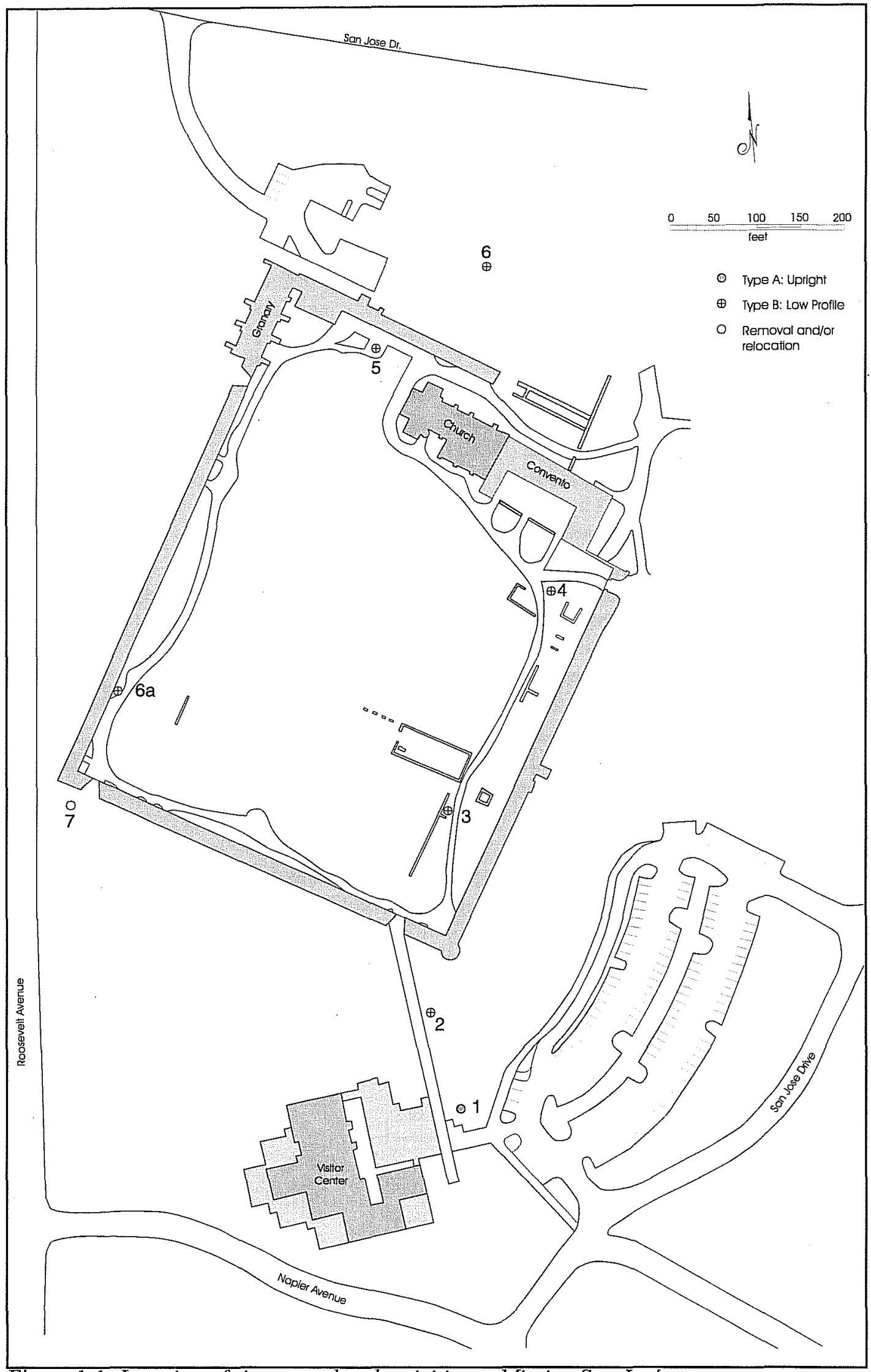

Figure 1-1. Location of signage-related activities at Mission San José. 
levels that correspond to the materials recovered. Glass, unidentified metal, and small pieces of unidentifiable bone fragments make up the bulk of the materials recovered. Ceramic material was relatively scarce. The majority of the ceramics recovered came from the upper three levels of ST 4 . We were informed by NPS personnel that this matrix had recently been introduced in conjunction with drainage grade improvements both within and outside the mission walls. It is likely that the artifacts recovered in this shovel test were introduced with this fill. For this reason it is unlikely that these artifacts are in their original context.

Another sherd found in association with sign no. $6 \mathrm{a}$, as well as two sherds associated with sign no. 6 , are identified as banded slip, decorated whiteware. This type of whiteware is dated to the early to mid-nineteenth century (Anne Fox, personal communication 1998). One sherd found in association with sign no. $6 \mathrm{a}$ is identified as being from a twentieth-century flower pot (Anne Fox, personal communication 1998).

\section{Machine Bored Holes at Mission San Juan}

Two machine-bored holes were dug at Mission San Juan (Figure 1-2). A single piece of undecorated whiteware ceramic was recovered.

Table 1-2. Artifacts from machine-bored holes at Mission San José

\begin{tabular}{|l|r|r|r|r|r|r|r|}
\hline $\begin{array}{c}\text { Sign/(Nr. } \\
\text { of Holes) }\end{array}$ & Ceramics & $\begin{array}{c}\text { Misc. } \\
\text { Metal }\end{array}$ & $\begin{array}{c}\text { Misc. } \\
\text { Glas s }\end{array}$ & $\begin{array}{c}\text { Constr. } \\
\text { Material }\end{array}$ & $\begin{array}{c}\text { Chipped } \\
\text { Lithics }\end{array}$ & $\begin{array}{c}\text { Animal } \\
\text { Bone }\end{array}$ & Totals \\
\hline Sign 2/(2) & 2 & & & & 2 & 1 & 5 \\
\hline Sign 3/(1) & & & & & & 2 & 2 \\
\hline Sign 5(1) & & & & & & 13 & 13 \\
\hline Sign 6(2) & 2 & & & & 1 & & 3 \\
\hline Sign 6a(1) & 3 & & 1 & 1 & & 3 & 8 \\
\hline Totals & 7 & 0 & 1 & 1 & 3 & 19 & 31 \\
\hline
\end{tabular}

The two holes bored for Sign 1, and the one bored hole for Sign 4 were sterile.

\section{Machine Bored Holes at Mission San José}

Eight machine bored holes were dug at Mission San José for the purpose of installing park-related signage (Figure 1-1). Table 1-2 presents the breakdown of the 31 artifacts recovered. The 19 pieces of bone recovered represent the highest percentage of artifacts recovered from machine bored holes at this site. Seven ceramic sherds were recovered from these holes and are found to cover a wide time-span from the late seventeenth century to the early twentieth century. Two of these sherds found in association with sign no. 2 are identified as lead-glazed wares. These date primarily to the eighteenth century. One sherd found in association with sign no. $6 \mathrm{a}$ is identified as an unglazed, Native American brownware, commonly referred to as Goliad ware (Mounger 1959). This type of ceramic dates to the end of the seventeenth century and eighteenth century.
Table 1-3. Artifacts from machine-bored holes at Mission Espada

\begin{tabular}{|c|r|r|r|r|r|r|}
\hline $\begin{array}{c}\text { Sign/(Nr. } \\
\text { of Holes) }\end{array}$ & Ceramics & $\begin{array}{r}\text { Misc. } \\
\text { Metal }\end{array}$ & $\begin{array}{r}\text { Mis c. } \\
\text { Glas s }\end{array}$ & $\begin{array}{r}\text { Constr. } \\
\text { Material }\end{array}$ & $\begin{array}{c}\text { Animal } \\
\text { Bone }\end{array}$ & Totals \\
\hline Sign 1(2) & 12 & 4 & 22 & 5 & 4 & 47 \\
\hline
\end{tabular}




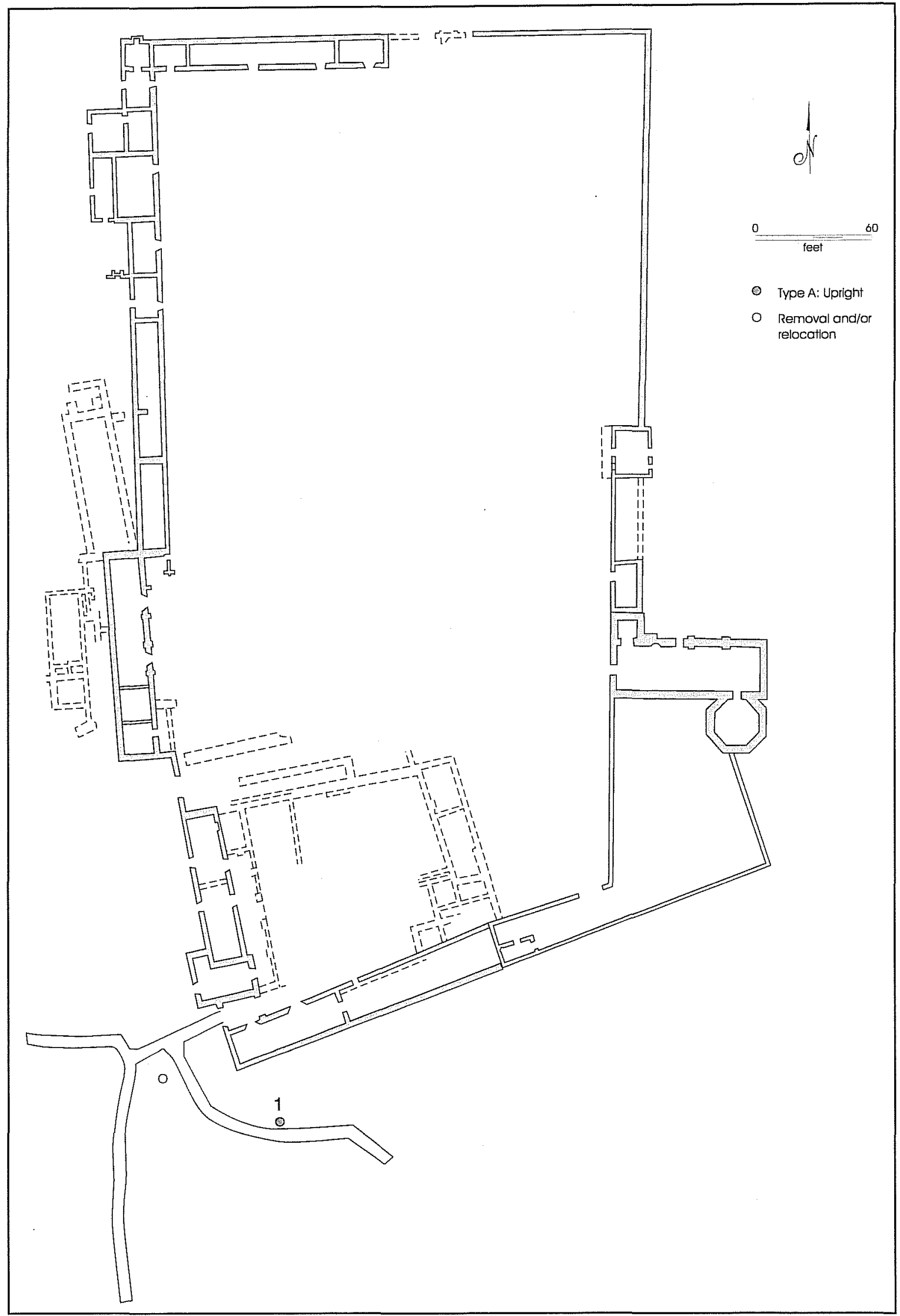

Figure 1-2. Location of signage-related activities at Mission San Juan. 


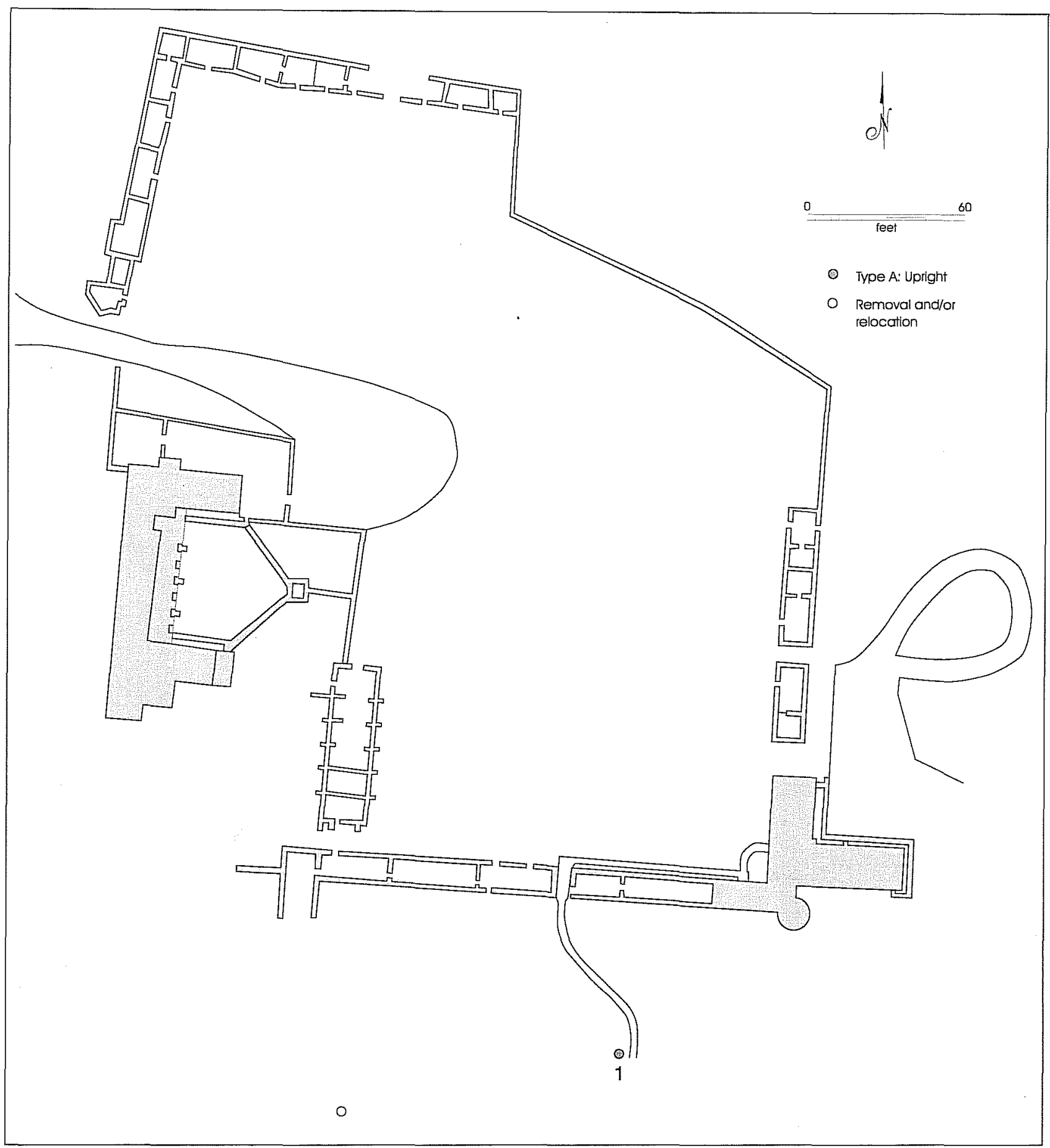

Figure 1-3. Location of signage-related activities at Mission Espada.

\section{Summary and Conclusions}

No artifactual material was observed from any of these holes.
Four shovel tests were excavated at Mission San José to a depth of 24 inches in conjunction with the placement of four park-related signs. These shovel tests revealed a small quantity of pre-colonial, colonial, and 


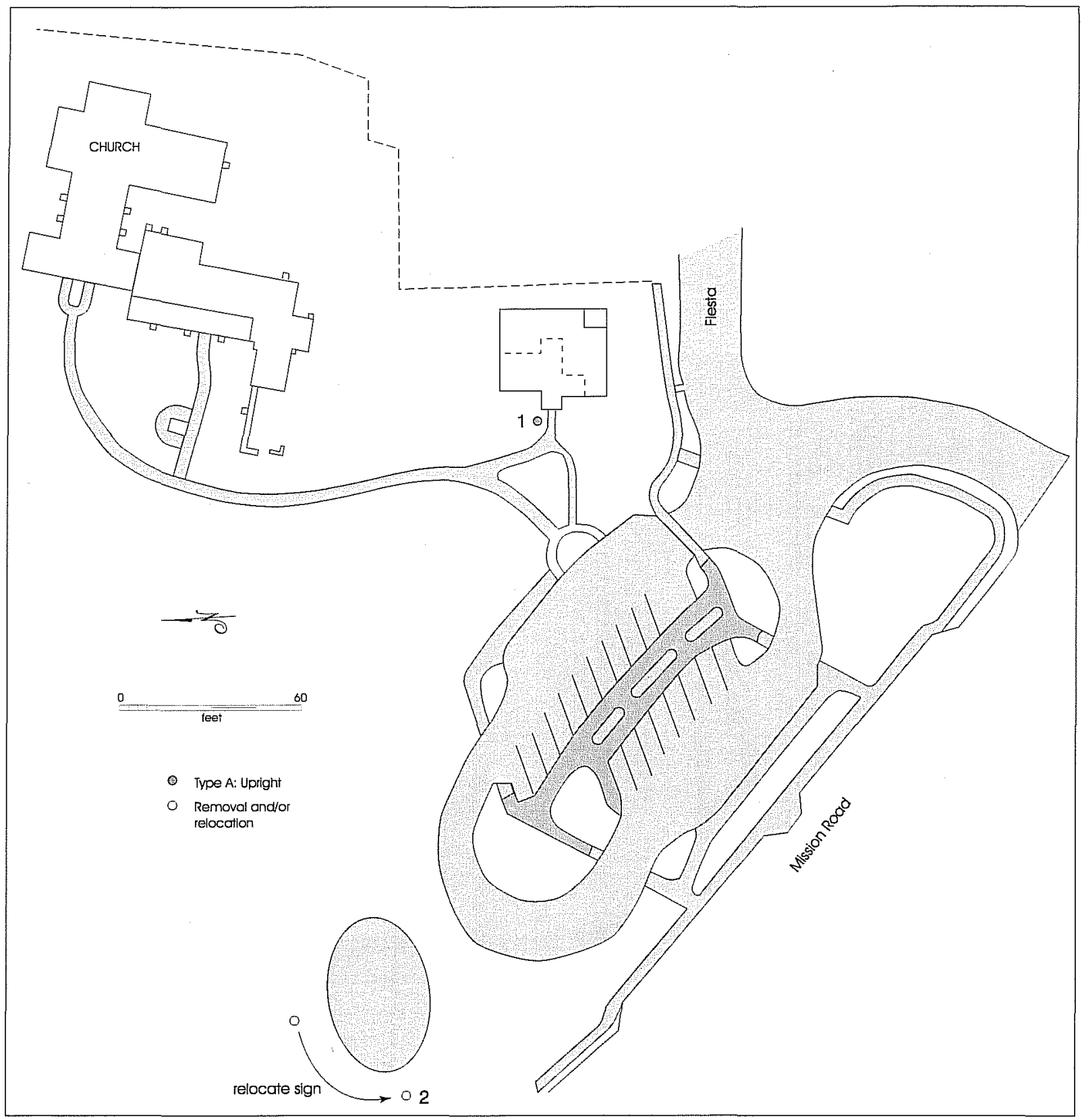

Figure 1-4. Location of signage-related activities at Mission Concepción.

nineteenth- and twentieth-century materials. The mixed nature of the deposits can probably be attributed to numerous construction activities that have taken place at Mission San José during its past history (Clark 1978; Tomka and Fox 1998).

Eighteen machine-bored holes were dug to a depth of 24 inches. These included ten at Mission San José, two at Mission San Juan, four at Mission Concepción, and two at Mission Espada. The artifacts recovered from these holes revealed a small quantity of artifactual materials that appeared to be in a mixed context.

In conclusion, it appears that the 12 to 18 inches of soil matrix below the ground surface at all four of the missions is disturbed and contains a mixture of artifactual material from various time periods. Below this depth, in some instances, there was a discernible soil change, but even at these depths the artifacts recovered remained mixed. 


\section{References Cited}

Clark, J. W., Jr.

1978 Mission San José y San Miguel de Aguayo: Archeological Investigations, December 1974. Texas Historical Commission, Archeological Report 29.

Hard, R. J., A. A. Fox, I.W. Cox, K. J. Gross, B. A. Meissner, G. I. Méndez, C. L. Tennis, and J. E. Zapata 1995 Excavations at Mission San José y San Miguel de Aguayo, San Antonio, Texas. Archaeological Survey Report, No. 218. Center for Archaeological Research, The University of Texas at San Antonio.

Mounger, Maria A.

1959 Mission Espiritu Santo of Coastal Texas: An Example of Historic Site Archaeology. Master's Thesis, The University of Texas at Austin.

Tomka, Steve A., and Anne A. Fox

1998 Mission San José Indian Quarters Wall Base Project. Bexar County, Texas. Archaeological Survey Report No. 278. Center for Archaeological Research, The University of Texas at San Antonio. 
